\title{
Profesní obraz školního speciálního pedagoga v podmínkách základní školy
}

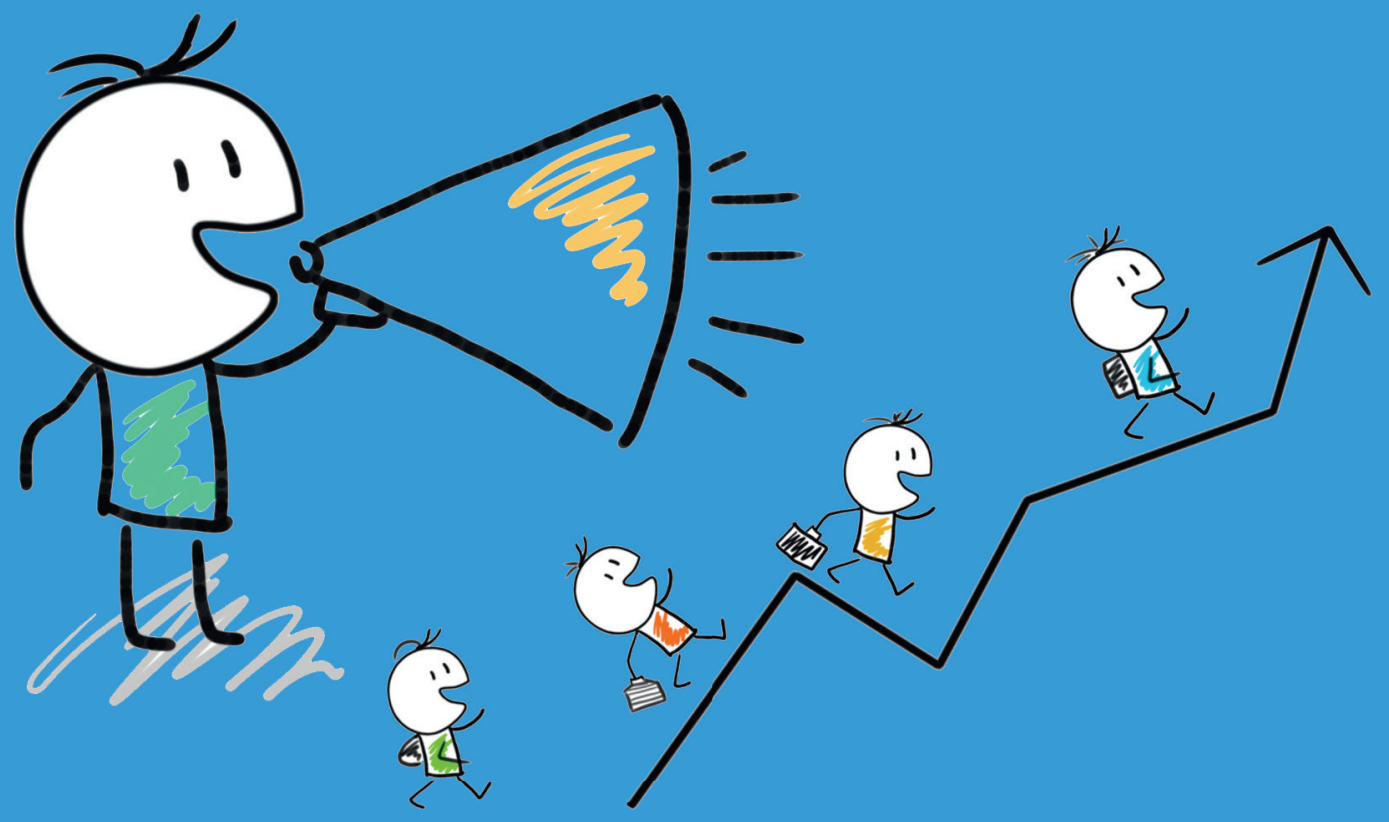

Tomáš Čech Tereza Hormandlová 
Univerzita Palackého v Olomouci

Pedagogická fakulta

\section{Profesní obraz}

školního speciálního

pedagoga

v podmínkách základní školy

Tomáš Čech, Tereza Hormandlová 
Odborní recenzenti: prof. Mgr. Kateřina Vitásková, Ph.D. (Univerzita Palackého v Olomouci) doc. PhDr. Věra Vojtová, Ph.D. (Masarykova univerzita)

Vydání publikace bylo podpořeno grantovým projektem Univerzity Palackého v Olomouci IGA_PdF_2020_013 s názvem Konformita a rizikové chování dětí školního věku.

Neoprávněné užití tohoto díla je porušením autorských práv a může zakládat občanskoprávní, správněprávní, popř. trestněprávní odpovědnost.

1. vydání

() Tomáš Čech, Tereza Hormandlová, 2020

Ilustrace na obálce @ RoonZ-nl, Pixabay.com, 2020

(c) Univerzita Palackého v Olomouci, 2020

DOI: $10.5507 /$ pdf.20.24458618

ISBN 978-80-244-5861-8 (tištěná kniha)

ISBN 978-80-244-5862-5 (online: ipdf) 


\section{Obsah}

1 Školní speciální pedagog v podmínkách základní školy $\quad 7$

1.1 Dlouhá cesta od segregace k inkluzi 8

1.2 Nástin vývoje inkluzivního vzdělávání v ČR a dalších zemích 14

2 Školní poradenské pracoviště a profese školního speciálního pedagoga 21

2.1 Školní speciální pedagog vs. speciální pedagog 21

2.2 Školní poradenské pracoviště a jeho poslání 22

2.3 Školní speciální pedagog a jeho role v poradenském systému školy 24

2.4 Školní speciální pedagog ve vztazích 30

3 Stres a další zátěžové faktory v práci školního speciálního pedagoga 38

3.1 Psychohygiena a pedagogická profese $\quad 40$

3.2 Copingové strategie a chování podporující kariéru 44

4 Etické aspekty profese $\quad 48$

5 Profesní obraz školního speciálního pedagoga ve výzkumné reflexi 53

5.1 Východiska a metodologie výzkumu 53

5.2 Profese školního speciálního pedagoga - výzkumná analýza 55

5.2.1 Od nutné agendy po odbornou spolupráci (otevřené kódování) 55

5.2.2 Spolupráce jako stěžejní aspekt práce školního speciálního pedagoga (axiální kódování) $\quad 77$

5.2.3 Profesní role školního speciálního pedagoga (selektivní kódování) 81

5.3 Specifika profese školního speciálního pedagoga shrnutí výsledků výzkumu $\quad 91$

5.4 Závěrečné shrnutí 94 
Obsah

Slovo závěrem

Použitá literatura

Seznam tabulek a obrázků

108

Věcný rejstřrík

109

Jmenný rejstř́ik

112

Shrnutí

115

Summary

116

O autorech

117 


\section{Předmluva}

Inkluzivní vzdělávání žáků se specifickými vzdělávacími potřebami je vysoce aktuálním tématem - naše společnost je velmi různorodá a po letech segregace a ignorování minoritních skupin se snaží nabídnout rovné př́ležitosti všem jedincům, a to jak z hlediska vzdělávání, tak také profesního a sociálního uplatnění. To však přináší do výchovně-vzdělávacího systému významný úkol, se kterým se musí nejen české školství, ale celá společnost vypořádat. Otevírání běžných škol všem žákům s rozmanitými specifickými vzdělávacími potřebami s sebou nese jisté překážky, ale současně výzvy a obohacení všech účastníků edukačního procesu, rovněž přispívá k potírání nudy a stereotypu ve školním prostředí. Je řada věcí, které se musely a stále ještě musejí ve školském systému změnit - mění se složení žáků ve tř́dách hlavního vzdělávacího proudu, na které musíme reflektovat nejen z hlediska nastavení prostředí, podmínek pro vzdělávání, pomůcek, hodnocení, financování atp. Zásadní a nutná je však také změna v postojích a př́stupech jak ze strany učitelů a vedení škol, tak rodičů a celé společnosti.

Se zmíněnými změnami se ve školách na základě vyhlášky 72/2005 Sb., o poskytování poradenských služeb ve školách a školských poradenských zařízeních, a následně v její novele - vyhlášce č. 116 ze dne 15. dubna 2011, kterou se mění vyhláška č. 72/2005 Sb., o poskytování poradenských služeb ve školách a školských poradenských zařízeních - etablují do poradenského systému škol nové odborné profese, a to školní speciální pedagog a školní psycholog, které rozšírily spektrum odborníků v rámci školního poradenského pracoviště a mnohé školy si již své fungování bez nich nedovedou představit. Především téma profese školního speciálního pedagoga z odborného hlediska vnímáme jako relativnĕ nové a nemáme $\mathrm{k}$ němu prozatím mnoho publikací a výzkumů. Proto jsme se rozhodli věnovat se mu blíže v aktuální odborné a výzkumné reflexi, která odráží více než patnáctiletou zkušenost působení školních speciálních pedagogů v českých školách.

V úvodních kapitolách publikace se pokoušíme reflektovat s oporou aktuálních odborných poznatků a legislativních dokumentů potřebu a pozici školního speciálního pedagoga v kontextu inkluze a inkluzivního vzdělávání, působení v rámci školního poradenského pracoviště a dalších institucí. Rovněž se zabýváme pojetím profese školního speciálního pedagoga, jeho rolí, pracovní zátěží a strategiemi, jak ji zvládat. Jelikož se jedná náročnou 
pomáhající profesi, která stojí na práci s lidmi, věnujeme se rovněž etickým aspektům profese, které provázejí všechny pomáhající profese a poskytují rámec a oporu pro jednání profesionálů. Zmíněná teoretická východiska vytváří konceptuální rámec pro výzkum zaměřený na profesní obraz školního speciálního pedagoga v podmínkách základních školy.

Pro výzkum a podchycení specifik profese školního speciálního pedagoga v podmínkách základní školy jsme zvolili kvalitativní výzkumný design. Na základě rozhovorů realizovaných s praktikujícími odborníky v této profesi a jejich následné analýzy prostřednictvím zakotvené teorie reflektujeme činnosti školního speciálního pedagoga, jeho pracovní zátěž a strategie zvládání, které tito profesionálové uplatňují. Vymezujeme rovněž profesní role a limity profese školního speciálního pedagoga. Cílem publikace tedy je zmapovat profesi školního speciálního pedagoga a nahlédnout do jeho života ve škole. Dále zjistit, jak školní speciální pedagogové vnímají svou pozici vůči dalším profesím, své místo ve společnosti a jak zvládají stres, který na ně tato náročná profese klade.

Kniha a související výzkum odráží předchozí odbornou spolupráci autorů (Hormandlová \& Čech, 2020) a její vydání bylo podpořeno projektem Univerzity Palackého v Olomouci IGA_PdF_2020_013 s názvem Konformita a rizikové chování dětí školního věku. Věříme, že publikace čtenářům odkryje mnoho zajímavých aspektů profese školního speciálního pedagoga v prostředí základní školy a vyjasní její společenskou roli a význam.

Autoři publikace 


\section{Školní speciální pedagog v podmínkách základní školy}

Pro pochopení kontextu působení školního speciálního pedagoga v prostředí základní školy nahlédneme na cestu inkluze od samých začátků až po dnešní situaci nejen v České republice, ale i v dalších vybraných zemích, jako jsou např́klad Švédsko nebo Rakousko. Tématu integrace a inkluze se dotkneme také z pohledu legislativního rámce. Dále se budeme zabývat profesí školního speciálního pedagoga, jemuž je tato kniha věnována. Budeme se zabývat školním poradenským pracovištěm, kde školní speciální pedagog v rámci školy působí, dále povinnostmi a agendou školního speciálního pedagoga a také vztahy, které $\mathrm{k}$ této profesi přísluší, jako například vztah mezi školním speciálním pedagogem a školou, žákem, rodiči, institucemi, ale také vztah školního speciálního pedagoga k jeho profesi a k sobě samému. Práce ve školství je spojena se stresem a vysokými nároky, proto se budeme také zabývat významem práce jako takové, stresem a strategiemi, jak se se zátěží vyrovnat nejen v zaměstnání, ale i v běžném životě. V realizovaném výzkumu analyzujeme způsoby zvládání stresových situací v pracovním procesu a postupy aplikované samotnými školními speciálními pedagogy.

V rámci teoretického ukotvení problematiky jsme analyzovali již realizovaná výzkumná šetření, která byla zacílena na profesi školního speciálního pedagoga. Mnoho prací se zabývá nejrůznějšími oblastmi, které se zaměřují na speciální pedagogy nebo školní psychology, nikoliv však na školní speciální pedagogy. Objevili jsme několik závěrečných bakalářských a diplomových prací na toto téma, avšak není jich mnoho. Tyto práce se zaměřují převážně na náplň profese, konkrétní činnosti ŠSP a spolupráci s dalšími institucemi, ale nemají hlubší výzkumné zacílení.

Př́kladem ucelenější teoretické publikace k tématu je Metodika práce školního speciálního pedagoga zapojeného ve školním poradenském pracovišti autorek Kucharská, Mrázková et al. (2014), která popisuje model péče, standardní činnosti ŠSP v oblasti podpory úspěšnosti ve škole a v oblasti problémového chování. Pojednává také o individuálních plánech a metodickém vedení učitelů, dále zmiňuje dokumentaci a formuláře, které spadají do agendy ŠSP. Nosná je také přehledová monografie Školní speciální pedagog z pera obdobného autorského kolektivu (Kucharská et al., 2013). Školní speciální pedagog je také zmíněn v učebním textu Otázky speciálně pedagogického poradenství - základy, teorie, praxe (Vítková, 2004). Uplatněním školních 
speciálních pedagogů a jejich kompetencemi se zabývají Pešatová a Matulayová (2013). Ve Zpravodaji IPPP se pak objevila sonda J. Mrázkové (2007) do profese školního speciálního pedagoga a následně její publikace Profese školního speciálního pedagoga (2008). Mrázková (2008) mapovala náplň práce školních speciálních pedagogů a jejich vztah k této činnosti. ŠSP spolupracují s pedagogy, rodiči a žáky na úpravě podmínek pro integraci žáků. Z jejího výzkumu vyplynulo, že nejčastější činností je náprava SPU, depistáž a diagnostická činnost, která je však komplikována nejednotností diagnostických kritérií.

\section{$1.1 \quad$ Dlouhá cesta od segregace k inkluzi}

Pro současné české školství je příznačný trend inkluzivního vzdělávání. Toto stadium nevyřazování osob s postižením z hlavního proudu je chápáno jako prozatím poslední přístup uváděný ve vývoji péče o osoby s postižením. Je patrná snaha o vytvoření prostředí školy, které bude poskytovat všem žákům stejné šance na dosažení adekvátního stupně vzdělání a zároveň bude respektovat právo na individuální rozvoj. Tato práva deklaruje Listina základních práv a svobod, která dokládá právo na vzdělání všech dětí. Toto stadium představuje kontinuální přechod z předešlého stupně integrace a dotýká se především reformy a rozvoje školství. Naplňují se inkluzivní ideje, že být jiný je normální. Jinakost již není vnímána jako negativní specifikum, ale je na ni nahlíženo jako na běžnou vlastnost, originalitu každé bytosti. Do této fáze však české školství a speciální pedagogika musely dospět po složitém politickém a společenském vývoji.

Společnost je mj. hodnocena podle toho, jaký je její přístup k občanům a jak se dokáže postarat o osoby se zdravotním postižením, jaký je vztah společnosti k těmto občanům a jaké priority a hodnoty společnost vyznává (Pešatová \& Tomická, 2007). V české speciální pedagogice je stále respektována periodizace tohoto vztahu vytvořená Sovákem, zakladatelem „defektologické“ speciální pedagogiky, uživané od roku 1972. Sovákovo dělení bývá podkladem pro další autory, mj. ho reflektuje a péči o osoby s postižením dále rozpracovává např́klad Jesenský (2000). Podle Sováka je první represivní stadium uplatňováno v době, kdy byla existence člověka vázána na sílu, zdatnost a odvahu. Šlo o období rané historie, kdy se společnost lidí s postižením zbavovala, odkládala je a zabíjela. Člověk v období antiky rozvíjí své myšlení, ovlivňuje směr života a tvoří první etické úvahy, avšak na počátku naší historie v raném a středním starověku, jak píše Janků (2013), dominuje odmítavý přístup k osobám s postižením. Je spojen s termíny jako vyloučení, opuštění či zabití. Jedinci s postižením byli považováni za neschopné a zatěžující společnost. Byli vnímáni jako bytosti bez životní perspektivy. Zvyklosti represivního přístupu se udržely velmi dlouho - Zezulková (2004) např́́klad uvádí, že likvidace postižených novorozenců byla běžnou praxí na Islandu ještě v 11 . století. 
V dalším období, dokud nenastoupila monoteistická náboženství, převažovalo ve společnosti otrocké využívání lidí s postižením. Proto jej Sovák označil jako stadium zotročování, v němž byli jedinci s postižením považováni za méněcenné a byli zneužíváni intaktní společností. Jesenský (2000) uvádí, že pro toto období je příznačný výběrově utilizační postoj. V židovské tradici se oproti antice objevuje odlišnost v myšlení. Člověk je odrazem Boha v tělesné i duchovní rovině (nikoliv pouze duchovní, jak tomu bylo v antice). Otázka, zda je postižení trestem za hříchy člověka, je zde, na počátku dějin lidstva, již odmítána. Byl platný zákaz zabíjení dětí s postižením, který vycházel z imperativu Nezabiješ! uváděném v Dekalogu a platil výhradně v Izraeli a Thébách, kde lidé s postižením dostávali přiměřené zaměstnání. Janků (2013) zmiňuje, že tomu tak bylo pravděpodobně proto, aby se nezmenšoval počet otroků, kteří byli využíváni k nejhrubší práci. Autorka dále připomíná, že zneužívání uchovaných možností a schopností lidí s postižením má i v našich krajích nezvykle dlouhou tradici.

V období středověku, kdy se upevnilo křest'anství, se v evropské společnosti uplatňovala specifická péče o postižené (Sovákovo stadium charitativní). Péče byla podmíněna křestianskou dobrosrdečností a základní vztahovou normou Miluj bližního svého jako sebe sama. Péče o osoby s postižením v období středověku patřila do působnosti církve a těmto jedincům byly zajištovány základní životní potřeby pro přežití. Při nemocnicích a klášterech vznikala první zařízení pro osoby s postižením, tzn. že charitativní období předznamenalo počátky institucionální péče o osoby s postižením (Janků, 2013). Nejednalo se však o výchovu a vzdělávání jedinců s postižením, ale o jejich ošetřování a péči o ně (Veselá, 2010).

V renesanci se zvýšil zájem o člověka a jeho důstojnost, hledal se lidský přístup k jedincům s postižením. Toto období můžeme datovat do 14.-16. století a významnou osobností tohoto období byl J. A. Komenský. Je to období humánně filantropických postojů. Myšlení typické pro starověk a středověk se proměnilo. Pro novověk s jeho objevy (objevení nových kontinentů, heliocentrismus aj.) a změnou chápání celého světa je typické kriticko-empirické myšlení a člověk se stává středem poznávání ostatních. V popředí renesančního humanismu je nutnost pomáhat druhým. Toto období ale Foucault (1994) definuje jako období protikladů. Pokrokové názory stály v opozici vůči církvi a jejím dogmatům a symbolem přechodu mezi středověkým a novověkým postojem společnosti je podle Foucaulta tzv. Lod' bláznů.

Na renesanční a humanistické období navazuje stadium altruisticko-segregačních postojů typických pro osvícenství (17.-19. století). Pozornost byla věnována konkrétním typům postižení a péče o hendikepované směřuje již k vyšším lidským potřebám. Zakládají se instituce, ústavy a zařízení pro jedince se smyslovým postižením a byl položen základ pro segregovanou výchovu vysoce specifikovanou na jednotlivé skupiny osob s postižením (Jesenský, 2000). 
Jesenský (2000) nazývá další stadium rehabilitačně-emancipační s podporou speciálního školství a ústavů. Toto období je ve znamení rozmachu služeb a péče o lidi s postižením. V 19. a 20. století se prosazují práva a svobody osob s postižením, s čímž souvisí i jejich možnost uplatnění se ve společnosti. Rozmach přichází i na poli vědy a techniky. Rozvíjejí se obory jako pedagogika, psychologie a sociologie. Dochází k rozvoji sociální politiky, ze strany státu přichází podpora všech členů společnosti (tzv. Welfare State). Sovák toto období nazývá rehabilitačním stadiem, ve kterém se významně zohledňují ekonomické aspekty organizace společnosti. Člověk s postižením by v takové společnosti měl najít své uplatnění i v pracovním procesu. Vznikají první speciální ústavy s léčebně-výchovným charakterem. Díky tomuto uplatnění člověk s postižením vrůstá do společnosti (Sovák tuto dobu označuje jako socializační stadium). Pešatová a Tomická (2007) píší, že společnost uznává lidi s postižením jako právoplatné občany.

Poslední stadium, které Sovák (1972) ve své kategorizaci uvádí, je prevenční stadium, ve kterém se společnost snaží předcházet vzniku poruch a v popředí zájmu je výhled do budoucnosti. Janků (2013) popisuje toto stadium jako období preventivně integračních postojů a zařazuje jej do období poslední třetiny 20. století. V tomto stadiu je typická pluralita hodnot a pravd a překonává se univerzalistické chápání a postavení člověka ve světě. Formulují se požadavky a specifika práv osob s hendikepem a aplikuje se Listina základních práv a svobod. Společnost se zaměřuje na rozvoj preventivních opatření proti vzniku primárních a sekundárních postižení, na zásady zdravého životního stylu a také na zařazování osob s postižením do intaktní společnosti. Integrace se týká všech oblastí života a všech aktivit. Předpokladem integrace je kompenzace poškozených funkcí a vysoký stupeň rozvoje uchovaných schopností (Veselá, 2010).

Během tohoto vývoje prošla společnost změnami a péče a pomoc lidem s postižením se rozvíjela až do dnešní úrovně. Organizovaná výchova a vzdělávání se však objevuje až s prvními odbornými ústavy přibližně počátkem 19. století. Systematičtější vzdělávání v ústavech se začalo objevovat v Evropě na konci 19. století. Př́́kladem bylo Ernestinum založené K. S. Amerlingem v roce 1871. V těchto ústavech vnikaly první pomůcky a první metodiky pro práci s dětmi s postižením, jako například tzv. pražská tabulka pro nevidomé nebo posunková řeč. Následně se zformovaly pedologie a pedopatologie jako nauka o dítěti a nauka o nemoci, ohrožení a postižení v dětském věku (Kucharská et al., 2013). Významnými jmény v tomto oboru jsou K. Herfort, J. Zeman a F. Čáda, který byl organizátorem sjezdů zaměřených na péči o slabomyslné. Z těchto sjezdů vznikly první sborníky, které měly hodnotnou odbornou úroveň. V této době probíhaly výchova a vzdělávání lidí s postižením segregovaně v daných ústavech rozčleněných dle typu postižení - tělesného, duševního, mravního (Titzl \& Vojtko, 2011). Ve výčtu osobností ovlivňujících vývoj speciálněpedagogického myšlení u nás nelze opomenout také odkaz zmiňovaného J. A. Komenského, dále F. Štampacha, O. Chlupa či M. Sováka. 
Počátky speciálního vzdělávání u nás částečně kopírují vývoj v Evropě a sahají do konce 19. století, kdy vznikaly první specializované ústavy. Mnoho dnešních ústavů bylo založeno po druhé světové válce, kdy byl také vytvořen organizační systém ústavní péče (Mühlpachr, 2001). V segregované péči však společnost pokračuje až do 20. století., dochází však k dalšímu intenzivnějšímu rozvoji oboru speciální pedagogika. Významným impulzem pro rozvoj speciální pedagogiky byly již zmiňované Čádovy sjezdy pro péči o slabomyslné a školství pomocné v letech 1909-1913. Dalším podnětem bylo také ustanovení nové vědecké disciplíny pedologie. Postupně dále vznikla jako komplementární obor k pedologii ve směru k osobám s postižením pedopatologie, která byla spíše medicínsky zaměřená. Návazně vznikla Mauerova nápravná pedagogika, což byl první ucelený koncept dnešního oboru speciální pedagogiky (Vojtko, 2010). V této době stoupají požadavky na vysokoškolskou přípravu budoucích učitelů, byla vytvořena nástavba pro absolventy pedopatologie a nápravné pedagogiky. V tomto nástavbovém studiu, které iniciovali J. Zeman a J. Mauer, se účastníci věnovali nauce o dětech úchylných, psychologii úchylné mládeže a překvapivě i prevenci, což bylo v dané době velmi pokrokové. Po prvorepublikovém studiu pedopatologie a nápravné pedagogiky přichází studium defektologie, kde působily již zmíněné osobnosti jako O. Chlup a M. Sovák, který byl profesorem defektologie, čímž se tento obor stal oborem vysokoškolským. Dle Sováka byla defektologie oborem, který zkoumal defektního člověka, př́činy a okolnosti defektu a definoval změny pramenící z defektu v oblasti psychické, somatické a sociální.

První polovina 20. století je příznačná snahou poskytnout zaopatření sociálního charakteru a poskytnout také určitý stupeň výchovy a vzdělání všem osobám, i když se ještě nedá hovořit o existenci samostatné odborné vědní disciplíny speciální pedagogiky, která jako samostatná věda vznikla až v druhé polovině 20. století. V této době je však nejen speciální pedagogika ovlivněna politickým systémem. Mezi lety 1948-1989 panovala vláda jediné politické strany, která zasahovala do všech oblastí lidského života. Tato doba je sice charakteristická významným rozvojem speciálního školství a ústavů, ale typická je segregace osob s postižením, a to nejen od intaktní společnosti, ale také segregací jednotlivých druhů postižení navzájem. Segregovala se také společenská odvětví péče o lidi s postižením (instituce z resortu školství, zdravotnictví a sociálních věcí), až vznikl vnitřně uzavřený systém a péči poskytoval lidem s postižením jeden jediný resort. Pokud se člověk stal tzv. nevzdělavatelným, nemohly mu být poskytnuty služby z resortu školství a byl výlučně umístěn do ústavu sociální péče (Michalík, 2003). Na počátku 9o. let 20. století se však tento resortismus stal překážkou pro transformaci speciálněpedagogické praxe i teorie (Renotierová, 2005).

Po roce 1948 se školství striktně rozdělilo do dvou vzdělávacích proudů. Jeden pro děti bez postižení (intaktní) a druhý tvořil komplex zařízení pro děti s postižením. V roce 1948 byl přijat zákon o jednotné škole, který zaváděl jednotné obecné vzdělání pro všechnu mládež od 6 do 15 let. Zákon zmiňuje 
jako součást systému školy pro mládež vyžadující zvláštní péči. Tyto školy jsou stavěny na úroveň prvního a druhého stupně jednotné školy (Kasíková, 2007). Zákon z roku 1960 pak existenci tohoto typu škol potvrzuje. Vzdělávací systém se rozdělil na dva proudy s maximální podporou segregace. I přesto však systém nebyl schopen zajistit přístup ke vzdělávání všem. Děti s nejtěžším typem postižení byly stále ze vzdělávání vyloučeny. Legislativa také umožňovala osvobození od povinné školní docházky. V otázkách vzdělávání rozhodoval národní výbor, v praxi mnohdy rozhodovali o zařazení dítěte ředitelé škol, kteří př́liš nedisponovali hlubší znalostí problematiky postižení. Jak uvádí Michalík (2003), často tak docházelo ke zneužití pravomoci.

Od roku 1984 začal platit nový školský zákon č. 29/1984 Sb., jenž vymezoval existenci široké sítě speciálních škol, které měly pomocí zvláštních výchovných a vyučovacích metod, prostředků a forem zabezpečit výchovu a vzdělávání žákům s postižením, žákům nemocným či oslabeným nebo umístěným ve zdravotnických zařízeních (zákon č. 29/1984 Sb.). Tento zákon neumožňuje vzdělávání dítěte s postižením ve škole hlavního vzdělávacího proudu a do zařazení dítěte neměl možnost zasahovat ani rodič. Osnovy speciálních škol byly v různé míře redukovány a bylo tak porušováno právo na stejné vzdělání pro všechny. V řadě institucí však pracovali lidé s odpovídajícím vzděláním a snahou o zlepšování podmínek vzdělávání a výchovy dětí s postižením. Ve speciálních školách vznikaly didaktiky a metodické postupy, používaly se rehabilitační a kompenzační pomůcky, které jinak nebyly běžně dostupné. Mnohdy vykazovaly vysokou úroveň zpracování (Michalík, 2003).

Významným kladem péče poskytované specializovanými institucemi byla možnost poskytnout individualizovanou péči a vzdělávání v menších skupinách vedených vyškoleným speciálním pedagogem, ve kterých mohou žáci zažívat úspěch. Po roce 1989 přichází kritika tohoto modelu z důvodů segregace, stigmatizace, a tím také zhoršení následného uplatnění jedince. Žáci z těchto škol jsou vychováváni a vzděláváni v nepřirozeném chráněném prostředí, což způsobuje v dalším životě problémy s přizpůsobením se sociálním situacím. Systém omezoval přirozené rodinné i širší sociální vazby dítěte s postižením. Často byly tyto děti umístěny do některého z ústavů a předány do péče odborníků brzy po narození (Michalík, 2003). Také v případě, že dětem s postižením bylo umožněno vzdělávání, byly umístěny do internátních škol pro děti s postižením a domů jezdily jen na víkend a o prázdninách. Důsledkem segregace osob s postižením byl nárust ekonomických, sociálních a psychologických bariér, které i přes snahu o jejich odbourání, přetrvávají v jisté míře dodnes.

Po roce 1989 vyvstalo mnoho požadavků na změny v oblasti vzdělávání. Diskuse o změnách se ovšem protahovaly a opravdové změny přinesl až zákon z roku 2004. Do té doby však začaly platit některé novely a vyhlášky, které postupně měnily určité oblasti našeho školství. Například vyhláška č. 291/1991 Sb., o základní škole, která potvrzovala možnost (nikoliv však povinnost) přijmout do školy dítě se zdravotním postižením. Vyhláška říká, že 
ředitel školy může zřídit speciální třídy pro žáky se sluchovým, zrakovým, mentálním a tělesným postižením a pro žáky s vadami řeči. Ředitel školy mohl také na základě žádosti zákonného zástupce dítěte a vyjádření pedagogicko-psychologické poradny nebo speciálněpedagogického centra zařadit do daného ročníku žáky se smyslovým či tělesným postižením nebo s vadou řeči, což vylučovalo integraci žáků s mentálním postižením. Michalík (2001) však píše, že v praxi byly děti s mentálním postižením také integrovány v běžných školách na základě žádosti školského úřadu MŠMT o výjimku. Integraci do MŠ pokrývala vyhláška č. 35/1992 Sb., o mateřských školách. Důležitá byla také vyhláška č. 127/1997 Sb., o speciálních školách a speciálních mateřských školách. Ta také rámcově vymezovala činnost speciálněpedagogických center, která vznikala právě koncem 9o. let. V roce 1994 vydalo MŠMT Metodické pokyny k integraci dětí se speciálními vzdělávacími potřebami, které v roce 2002 nahradila Směrnice k integraci dětí a žáků se speciálními vzdělávacími potřebami do škol a školských zařízení. Ministerstvo školství v roce 1990 vypracovalo Nárys koncepce výchovy a vzdělávání dětí se zdravotním postižením. Podle této koncepce měla výchova a vzdělávání dětí s postižením probíhat primárně v běžných školách s dětmi intaktními. Pro děti, pro které tento způsob vzdělávání není vhodný, je určeno speciální školství (Michalík, 2003).

Největší podporu pro vstup do běžných škol měly děti s tělesným postižením. V 90. letech 20. století byly tyto děti vzdělávány v bariérových běžných školách, často bez pomoci asistenta i bez materiálních podmínek. Byla nezbytná účast rodiny a nadšená pomoc ze strany školy. Postupně se vytvářel systém podmínek pro zajištění integrace žáků nejen se somatickým postižením. Ve speciálněpedagogických centrech se utvořily týmy psychologů, sociálních pracovníků a speciálních pedagogů; někdy také probíhala spolupráce s rehabilitačními pracovníky. Vznikla také střediska rané péče zaměřená na ranou podporu dítěte s postižením a jeho rodiny, která však nespadají do systému školských poradenských zařízení. Tato poradenská pracoviště lze považovat spolu se speciálními školami za důležité aktéry transformace. Jedná se o odborná centra, která postupně vytváří odborné a materiální zázemí pro podporu integrace žáků se SVP do běžného proudu vzdělávání (srov. Kovářová \& Vitásková-Janků, 2008; Pilař, 2010; Kucharská et al., 2013).

V této kapitole jsme si definovali stadia vývoje péče o postižené na základě historických období: represivně lhostejné období, charitativní, humánně filantropické, altruisticko-segregační, rehabilitačně-emancipační, preventivně integrační a inkluzivně nevyřazovací. Každé z těchto období s jeho specifiky přineslo pro formování oboru speciální pedagogika a přístup k jedincům s postižením své výhody i nevýhody. Speciální pedagogika se nejprve vyvíjela z původního sociálního, léčebného a somatopatologického zaměření oboru, koncem 20. století se začala formovat speciální pedagogika jako jednoznačná disciplína, jež vychází z kulturních a společenských strategií, ale také strategií legislativních. Rozvinula se do oboru, který má za cíl překonávání hendikepů, prevenci, řešení problémů, rozvoj osobnosti, socializaci a integraci 
v rámci všech věkových kategorií osob se zdravotním postižením nebo sociálním znevýhodněním. Stejně jako obor speciální pedagogika se rozvíjela i profese speciálního pedagoga. Ta se odvíjela od teoretických poznatků, praktických a legislativních možností oboru až do dnešní povahy, kdy proniká také do škol běžného vzdělávacího proudu.

\section{Nástin vývoje inkluzivního vzdělávání v ČR a dalších zemích}

Nárůst poznatků koncem 20. století v oborech pedagogiky, psychologie, sociologie a speciální pedagogiky podmínil významné transformace ve 21. století. Kulminace segregačního trendu a separace ve vzdělávání v polovině 20. století vyvolala v přístupu k osobám s postižením potřebu modifikace. Společnost se přiklonila $\mathrm{k}$ integračním trendům a přirozenému začleňování jedinců s postižením či znevýhodněním do majoritní společnosti. To znamená, že vedle sebe nadále existují rozdílné skupiny dětí, avšak děti s postižením mohou s poskytnutím odpovídající podpory navštěvovat běžnou školu, což jim umožňuje kooperovat a rozvíjet se s intaktními dětmi. V takovém případě se jedná o duální systém, v němž existuje paralelní integrativní a segregovaná edukace (Lechta, 2010). Integrace se však netýká jen vzdělávání, ale celkového přístupu společnosti k lidem s postižením. Je to dynamický proces ovlivňující interpersonální i skupinové vztahy a identitu jedince i skupiny. Hovoříme zde o sjednocování hodnot, postojů a směřování lidí. Integrace, která je v demokratické společnosti podložena právními normami, pomáhá překonávat problémy společnosti a vzájemným vztahem lidí s postižením a intaktních obohacuje obě skupiny (Jesenský, 2000).

V zahraničí je trend integrace typický pro 80. léta 20. století, diskuse ohledně konceptu inkluze se pak objevila již v 9o. letech 20. století a počátkem 21. století. V českém prostředí existoval jednotný vzdělávací systém až do roku 1989. Teprve po roce 1991, kdy se ve světě začal již rozvíjet teoretický koncept inkluze, se u nás objevily první možnosti zařazení dítěte do běžného vzdělávacího proudu. Podle Scholzova (2007, in Lechta 2010) dělení rozlišujeme několik přístupů k edukaci osob s postižením, v různém kontextu zmíněných již v předcházející podkapitole. Jedná se o naprosté vylučování ze vzdělávacího procesu (exkluzi), dále segregaci, tedy dělení osob s postižením dle určitých kritérií, jako je např́klad druh nebo stupeň postižení, a tím na edukační podskupiny v separovaných zařízeních (za existence dvou vzdělávacích proudů - speciálního a běžného školství). Dalším přístupem je integrace, kde stále existují dvě skupiny - děti s postižením a děti intaktní. Děti s postižením však mají možnost se s poskytnutím patřičné podpory vzdělávat v běžném vzdělávacím proudu, ale stále mají možnost vrátit se do proudu speciálního vzdělávání. Na integraci pak již navazuje pro naše potřeby klíčový přístup 
inkluze, kde je odlišnost vnímána jako norma, původní systém postupně zaniká a všechny děti jsou vzdělávány v jediné skupině. Dnes i v ČR můžeme hovořit o transformaci směrem k inkluzivnímu vzdělávání. Scholz (2007, in Lechta 2010) uvádí ještě další stadium, a to různorodost je normální, jehož podstatou je dovršení procesu inkluze. V tomto stadiu se již inkluze stává samozřejmostí.

Inkluzivní trendy vedou ke společnému vzdělávání všech žáků v hlavním vzdělávacím proudu dostupném všem bez rozdílu a očekává se, že takové vzdělávání bude nástrojem sociální inkluze (Lazarová et al., 2015). Přičemž Pilař (2010) píše, že ve vyspělém světě je integrace či inkluze první volba, první alternativa. V českém prostředí mají inkluzivní tendence oporu v legislativě, která byla zmíněna na začátku této kapitoly. Pilař (2010) dále shrnuje, že se po celé Evropě postupně upouští od uživání lékařské diagnostiky a přechází se k popisu žákových schopností. Snahou speciálního vzdělávání je vycházet ze schopností žáka namísto z jeho oslabení. V zemích EU došlo k zásadním změnám v legislativě. Systém speciálního školství je v těchto zemích chápán jako odborné metodické zázemí pro běžné školy, rodiče mají právo vybrat svému dítěti vzdělávací cestu a klade se důraz na spolupráci rodiny a školy, přičemž integrace je první alternativou. V zemích, kde je oddělený systém běžného a speciálního školství, je vypracován společný legislativní rámec.

Podmínky pro začlenění žáků s postižením do hlavního vzdělávacího proudu se tedy postupně zlepšovaly a zlepšují, a to i díky ukotvení v legislativě. Postupně hovoříme o integrovaném a inkluzivním vzdělávání. Školství v ČR, ale i jiných státech EU, však často stále tvoří dvě linie - speciální školství, které má své odpůrce i příznivce, a hlavní vzdělávací proud. Speciální školy jsou určeny pro žáky, kteří vyžadují značnou míru speciálněpedagogické péče. V těchto školách se naplňuje právo na vzdělávání žáků, kteří byli dř́ve mnohdy od povinné školní docházky osvobozeni (Pilař, 2010).

Celosvětová podpora inkluzivního vzdělávání rozdělila laickou i odbornou veřejnost na dvě skupiny. Jedna skupina obhajuje široké pojetí inkluze, druhá je zastáncem speciálního vzdělávání. Podpora inkluze však neznamená absolutní rušení speciálních škol (Kratochvílová, 2013). Rovnocenné začlenění dětí do hlavního vzdělávacího proudu nevylučuje možnost volby speciálního zařízení pro ty žáky, pro které je to žádoucí. Speciální školy jsou tedy jako alternativa určeny žákům, kteří se nemohou vzdělávat v hlavním vzdělávacím proudu nebo jim toto vzdělávání nevyhovuje (Resman, 2003).

Pokud jde o legislativu, v našich podmínkách lze za průlomový považovat zákon č. 561/2004 Sb., o předškolním, základním, středním, vyšším odborném a jiném vzdělávání (školský zákon), který vymezil paragrafem 16 žáky se speciálními vzdělávacími potřebami, kam dle tohoto zákona spadá zdravotní postižení, zdravotní znevýhodnění a sociální znevýhodnění. Novela tohoto zákona nese označení 46/2019 Sb. a nově definuje žáka se speciálními vzdělávacími potřebami takto: „Dítětem, žákem a studentem se speciálními vzdělávacími potřebami se rozumí osoba, která k naplnění svých vzdělávacích 
možností nebo k uplatnění nebo uživání svých práv na rovnoprávném základě s ostatními potřebuje poskytnutí podpůrných opatření. Podpůrnými opatřeními se rozumí nezbytné úpravy ve vzdělávání a školských službách odpovídající zdravotnímu stavu, kulturnímu prostředí nebo jiným životním podmínkám dítěte, žáka nebo studenta.“

Školský zákon také provází vyhláška MŠMT č. 73/2005, nyní její novela č. 27/2016 Sb., o vzdělávání žáků se speciálními vzdělávacími potřebami a žáků nadaných (Kucharská et al., 2013). V současnosti je úspěch integrace závislý na finančních prostředcích, ale také na ochotě a přístupu školy a jejích pedagogů. Integrace žáka v základním vzdělávacím proudu je proces, pro který jsou nezbytná podpůrná opatření poskytovaná školou a školským poradenským zařízením. Kucharská et al. (2013, s. 20) dále chápou inkluzi „jako proces, kde žák s postižením, znevýhodněním a oslabením bude mít naprosto rovnoprávné postavení ve škole a škola se stane vzdělávací institucí pro všechny žáky bez rozdílu (např. postižení, národnosti)“. Tyto myšlenky jsou zakotveny v mnoha českých i mezinárodních dokumentech. Př́́kladem je již zmíněný školský zákon, Všeobecná deklarace základních lidských práv a svobod, jejíž článek 33 v hlavě IV. ustanovuje právo každého na bezplatné vzdělávání a přístup ke vzdělávání pro všechny, Úmluva o právech osob se zdravotním postižením (schváleno OSN v roce 2006), Ústava ČR, článek 26 UN konvence, kde téma inkluze intenzivně nabývá na významu, dále antidiskriminační zákon č. 198/2009 Sb., o rovném zacházení a právních prostředcích ochrany před diskriminací a o změně některých zákonů, Bílá kniha, Akční plán inkluzivního vzdělávání na období 2019-2020 (či jeho předchůdce z období 2016-2018), který vychází z priorit a trendů vzdělávací politiky ČR ustanovených ve Strategii vzdělávací politiky v ČR do roku 2020. Akční plán obsahuje tři strategické cesty - jednak informace a komunikace, dále škola, pedagog, žák a konečně mezioborová spolupráce.

Snahy o inkluzivní vzdělávání se v různých zemích EU nacházejí na odlišných úrovních. Existují různá východiska od rozsáhle pojaté inkluze po jasně oddělený běžný a speciálněpedagogický systém. Rozdíly jsou patrné také v definicích a kategoriích speciálněpedagogické podpory.

S inkluzí, zejména jejím širším pojetím, souvisí také pojem diverzita jako komplexnější pojem, na který je nahlíženo jako na hodnotu, ale i výzvu (European Agency for Development in Special Needs Education, 2011). Speciální vzdělávací potřeby lze vnímat jako přirozenou součást diverzity společnosti, kde různorodost není nenormální a je přijímána. Koncept diverzity zahrnuje demografické deskriptory jako gender/pohlaví, socioekonomický status, etnicita a kultura, jazyk, náboženství, ale zahrnuje také schopnosti, dovednosti a osobnostní charakteristiky (Kasíková, Straková, 2011). Přijetí diverzity ovlivňuje silné postoje společnosti ve prospěch segregace ve vzdělávání jak pro žáky se speciálními vzdělávacími potřebami, tak např́iklad také pro žáky nadané (Greger et al., 2009; Pančocha \& Slepičková, 2012). 
European Agency for Development in Special Needs Education v roce 2003 publikovala zprávu, ve které analyzovala programy a metody vzdělávání v 18 evropských zemích. Rozdělovala tyto země do tří kategorií dle jejich politiky vzhledem k žákům se speciálními vzdělávacími potřebami. První kategorie, pro kterou je příznačný tzv. jednostranný, jednokolejný př́stup (one-track approach), zahrnuje ty země, jejichž politika a praxe zahrnuje téměř všechny žáky do hlavního vzdělávacího proudu, v němž jsou žáci podporováni širokou škálou služeb. Mezi tyto země patří například Španělsko, Řecko, Itálie, Portugalsko, Švédsko, Island nebo Norsko.

Do druhé kategorie spadají země jako Dánsko, Francie, Irsko, Lucembursko, Rakousko, Finsko, Spojené království, Lotyšsko, Lichtenštejnsko, Estonsko, Litva, Polsko, Slovensko, Slovinsko a Česká republika. Tyto státy mají vícero přístupů k inkluzi, tedy náležejí do skupiny zemí s vícestopým/vícekolejným přistupem (multi-track approach). Nabízí řadu služeb mezi hlavním vzdělávacím proudem a speciálním vzděláváním. Tyto země se zaměřují na různorodost podpory hlavního vzdělávacího proudu i na systémy vzdělávání zaměřené na problematiku speciálních potřeb (Jílek, 2013).

Třetí kategorie je dvoustopý/dvoukolejný přistup (two-track approach), kde existují dva odlišné vzdělávací systémy a žáci se speciálními vzdělávacími potřebami jsou obvykle umístěni ve speciálních školách či třídách, které zpravidla (nebo alespoň do nedávna) sledují odlišné kurikulum než běžný vzdělávací proud a také se na ně vztahuje jiná legislativa s odlišnými zákony pro speciální školy a třídy, včetně speciální podpory v rámci třídy hlavního vzdělávacího proudu. Zároveň je dobře rozvinutý systém speciální podpory v rámci tříd hlavního vzdělávacího proudu (Jílek, 2013).

Existence dvoukolejného systému v základním vzdělávání je důsledkem dlouholeté tradice segregovaného vzdělávání. V anglosaské literatuře nese politika koexistence označení two tracks policy, tedy dvoucestná politika, a je na ni pohliženo jako na vlažnou integrační politiku, která podporuje nerovné šance na vzdělávání (Wilhelm, Bintinger \& Eichelberger, 2002). Kratochvílová (2013) ve své práci Kvalita inkluzivní školy: její hodnotová dimenze a podmínky poukazuje na jejich vysokou míru v našem vzdělávacím systému a zmiňuje některé národní i mezinárodní studie jako např́klad Straková (2009), Santiago et al. (2012) nebo Straková, Simonová a Polechová (2011). Naposledy zmíněné autoky připomínají, že se čeští žáci se zdravotním postižením dlouhodobě vzdělávají především v prostředí speciálního školství, jejich přítomnost v běžném proudu je méně častá a vychází zejména z přání a potřeb rodiny žáka. Poskytování prostředků speciálněpedagogické podpory bylo dle Strakové nedostatečné a skupina žáků se sociálním znevýhodněním stála dlouho dobu mimo hlavní zájem opatření v českém školství. Dnes, s odstupem dalších let můžeme toto tvrzení považovat za přežité - dvoukolejný systém v našich podmínkách přechází ve vícekolejný systém, který lépe reflektuje konkrétní vzdělávací a individuální potřeby dítěte s postižením. 
Vývojová úroveň zemí se samozřejmě liší. Země jako Švédsko, Dánsko, Itálie a Norsko jsou v přední linii inkluzivní politiky - v těchto zemích byla hlavní legislativní rozhodnutí stanovena dříve a v posledních letech již nedochází k tak výrazným změnám jako v jiných zemích. Např́klad Bartoňová a Vítková (2019) řadí mezi přední země, které aktuálně kladou na inkluzivní vzdělávání velký důraz, Švédsko, Finsko, Itálii a USA. Cíl vyučovat všechny žáky v jedné škole se snaží tyto země realizovat pomocí široké škály podpůrných opatření a služeb speciálněpedagogické péče. Základem finského vzdělávání je jednotná devítiletá základní škola, která byla zaváděna v počátku 70. let a nahradila předchozí selektivní dvoukolejný systém. Průcha a Kansanen (2015) píší, že podle tamního zákona o základním vzdělávání č. 628/1998 s dodatky z roku 2013 není základní škola dělena na stupně a v mezinárodní klasifikaci vzdělávacích systémů Eurydice je označována jako single structure school. Autoři dále uvádějí, že v praxi existují dva stupně základní školy - v nižších třídách, 1.-6. ročnících, vyučuje většinu předmětů jeden učitel (class teacher), ve vyšších ročnících (7.-9. ročník) vyučují jednotlivé předměty specializovaní učitelé (subject teacher).

Specifika švédského školského systému zmiňují ve své publikaci autorky Bartoňová a Vítková (2019). Uvádějí, že ve Švédsku jsou, stejně jako i v jiných zemích, na škole přítomni speciální pedagogové a asistenti pedagoga a řídí se jednotným školským systémem. Řadí tak Švédsko do one-track approach systému. Školský zákon ukládá škole odpovědnost za zajištění přiměřené podpory a pomoci všem žákưm. Podpưrné formy jsou velmi rozmanité a obsahují i technické pomůcky a materiální vybavení (Josefsson, 2002). Ve Švédsku však mohou být ve třídě také dva pedagogové a existují i dva typy asistentů. První, tzv. elevassistent (student assistant), který podporuje studenty se SVP (Thorup \& Thorup, 2006), a druhý, tzv. lärarassistent (teaching assistant), který podporuje učitele, aby měli více prostoru soustředit se na výuku. Asistenti pedagoga pưsobí jak v předškolním vzdělávání, tak na základních a středních školách (Skolverket, 2019; Kommunal. nedat.). Elevassistant (asistenti studentů, žáků) jsou součástí poskytování inkluzivního vzdělávání ve Švédsku, kde je inkluzivní politika podporována od 9o. let 20. století (Skär, Tam, 2001). Iatridou (2016) píše, že ačkoliv se může zdát, že ti, kdo jsou v jiných zemích nazýváni jako asistenti učitele (teaching assistant, teacher aides, classroom support, lärarassistent), ve Švédsku pracují jako elevassistent (student assistant, asistent studenta, osobní asistent). Nicméně Iatridou píše, že ve Švédsku existuje jak profese elevassistent, tak lärarassistent, tedy jak asistenti podporující začleňování, tak asistenti podporující učitele. Nejedná se tedy o synonymum, nýbrž dvě různé pracovní pozice.

Systém Velké Británie autorky Bartoňová a Vítková (2019) považují za systém kombinovaný, tzv. multi-track approach. Nachází se zde systém speciálních škol a škol hlavního vzdělávacího proudu, současně je nabízena široká sít podpůrných služeb. V první řadě se hledí na potřeby jednotlivých žáků a školy disponují nabídkou speciální podpory. Pro podporu inkluzivní praxe 
byl vytvořen Index inkluze (Index of Inclusion, Booth \& Ainscow, 2002), který popisuje indikátory podporující inkluzi a může sloužit k autoevaluaci. Není to uzavřený návod a striktně daný postup, ale spíše soubor ukazatelů směřujících k rozvoji školy na základě inkluzivních hodnot (Česká odborná společnost pro inkluzivní vzdělávání).

Pokud se týká vzdělávacího systému v Německu, autorky Bartoňová a Vítková (2019, s. 22) ve své publikaci uvádějí: „Co se týče vzdělávací politiky, patří Německo, podobně jako Česká republika, k zemím s př́stupem two-track-approach, přičemž aktuální vzdělávací politika směřuje k přistupu multi-trackapproach, jako výše uvedená Velká Británie. V současné době stále ještě existují dva oddělené školské systémy a žáci se speciálními vzdělávacími potřebami se mohou vzdělávat ve speciálních školách. "Nicméně European Agency for Development in Special Needs Education ve své zprávě již v roce 2003 zařadilo Českou republiku do systému multi-track approach. Německo pak bylo označeno jako země patřící do kategorie dvoukolejného přístupu, avšak s důrazem na aktuální změny ve vzdělávací politice, které vedou k přechodu do vícekolejného př́stupu.

V některých německých zemích, stejně jako v mnoha dalších státech, existují dva oddělené systémy běžného a speciálního vzdělávání (dvoukolejný přístup), kdy se žáci a jejich rodiče rozhodnou pro inkluzivní běžnou školu, nebo pro školu speciální s tím, že konečným cílem je i nadále inkluzivní vzdělávání (UNESCO, 2005). V Německu stále dochází k mnoha změnám směřujícím k inkluzivnímu vzdělávání. Konkrétně se jedná o cíleně diferencované vyučování směřující ke spolupráci a aktivitě. Zaměřují se také na odstraňování bariér při vstupu do pracovního procesu (Jennessen et al., 2010). Stejně jako u nás, i v Německu se stala UN konvence a Úmluva o právech osob s postižením základem pro směřování k inkluzivnímu vzdělávání. Vedle vzdělávání žáků se specifickými potřebami je pro Německo velkým tématem i vzdělávání socioekonomicky znevýhodněných, at' už s migračním kontextem, či bez něj (Werning \& Avci-Werning, 2015).

V Rakousku byla reforma školství odstartována již před desítkami let. V roce 1993 byl přijat zákon, který umožnil integraci v základních školách a rodičům nabídl volbu vzdělávací cesty jejich potomků. Do této doby byla povinná exkluze ve speciálních školách (Pilař, 2010). Nyní Rakousko se svým Národním akčním plánem postižení (Nationaler Aktionsplan 2.0), který, jako již druhý v pořadí, přijalo v roce 2016, směřuje k inkluzi a deklaruje právo člověka na vzdělávání. Jeho cílem je zajistit, aby začlenění bylo zásadou, kterou je třeba brát v úvahu ve všech aspektech života. Jejich cílem jsou společné školy pro všechny a dosažení co nejvyššího vzdělání skrze individuální přístup a flexibilní vnitřní diferenciaci, a to za pomoci přístupu ke zdrojům. Inkluzivní škola v Rakousku, k jejímž znakům patří uznání a ocenění různosti, klade důraz na kulturu školy (Dyson, 2010). Dalšími znaky jsou připravenost vzdělávací nabídky pro všechny žáky, spolupráce mezi učiteli a podpora spolupráce mezi žáky, ale též personálem školy nebo rodiči. Zaměřují se na prvky 
individualizace a diferenciace (Feyerer, 2015). V roce 2008 v souladu s evropskými trendy a s tradicí o usilování o jednotnou školu započala v Rakousku reforma nižšího sekundárního stupně, která měla být dokončena v roce 2018. Měla zajistit spravedlivý přístup ke vzdělání, jelikož vzdělávací model nižšího sekundárního stupně byl do roku 2008 charakteristický vysokou mírou vnější diferenciace a vysokým počtem různých škol, na kterých mohli žáci pokračovat po ukončení Volksschule, tedy primární školy (Bundesministerium für Bildung, 2016). Reforma měla přinést především to, že žáci nižšího sekundárního stupně nebudou děleni do skupin dle výkonnosti, ale budou se vzdělávat společně. V. Štastný (2017) píše ve své zprávě z univerzitního pobytu ve Vídni, že vícekolejnost, která měla být touto reformou odstraněna, zůstala zachována. Reforma zavedla novou nižší sekundární školu (Neue Mittelschule), nicméně vedle ní stále koexistují nižší akademické sekundární školy (gymnázia). Ke skutečnému zavedení jednotné školy tedy nedošlo. Štastný cituje názor pracovnice Institutu věd o vzdělávání, která říká, že k úplnému sjednocení ani v budoucnu nedojde kvưli silnému lobby, jež gymnázia mají. Pakliže by k jejich zrušení opravdu došlo, posílil by podle této pracovnice soukromý sektor. 


\section{Školní poradenské pracoviště a profese školního speciálního pedagoga}

V denní praxi škol se mohou objevovat problémy, ke kterým je nutno přizvat odborníka. Může se jednat o problémové chování či vývojové obtíže žáků nebo potřebu podpořit pedagogy, společné vzdělávání a rovné příležitosti v přístupu ke vzdělávání. Pro tyto případy byl vybudován systém pedagogicko-psychologického poradenství, který měl zajistit podporu žákům i učitelům v řešení specifických problémů a situací a s cílem zefektivnit výchovně-vzdělávací proces ve škole. Jeho odborníci však působili především mimo školu, proto je od 9o. let 20. století patrná potřeba posílit poradenské služby přímo v prostředí školy (Kovářová \&Vitásková-Janků, 2008; Kucharská et al., 2013; Kucharská, in Valentová, 2013). Odborníci, konkrétně školní psychologové, školní speciální pedagogové a školní metodikové prevence podpořili funkci výchovného poradce a nyní společnými silami směřují aktivity ve prospěch žáků, rodičů i učitelů s cílem podporovat rovné př́ležitosti ke vzdělávání a k učení všech dětí včetně dětí s postižením, a to přímo ve škole. Michalík, Baslerová, Felcmanová et al. (2015) však konstatují, že pozice speciálního pedagoga a školního psychologa nejsou v běžných školách stále dostatečně obsazené.

Zmíněné poradenské služby jsou ve školách poskytovány v rámci školního poradenského pracoviště, jež řídí vyhláška č. 72/ 2005 Sb., o poskytování poradenských služeb ve školách a školských poradenských zařízeních. Tato vyhláška byla v roce 2016 novelizována pod číslem 197/2016 Sb. Poradenský systém dále tvoří školská poradenská zařízení, kam patří pedagogicko-psychologické poradny (PPP) a speciálněpedagogická centra (SPC). Posledním typem jsou střediska výchovné péče (SVP), která však spadají pod resort Ministerstva práce a sociálních věcí (Kucharská et al., 2013).

\section{1 Školní speciální pedagog vs. speciální pedagog}

Mezi školním speciálním pedagogem a speciálním pedagogem je rozdíl, který není zcela znám laické veřejnosti, ale v průběhu psaní této publikace jsme narazili na překvapující fakt, že i ve školním prostředí není tento rozdíl zcela jasný a tyto profese bývají zaměňovány a jsou považovány za synonyma. Rozdíl je však zásadní. Speciální pedagog působí na škole jako učitel ve školách 
hlavního proudu nebo ve školách speciálních, může také působit v institucích jako SPC nebo PPP. Oproti tomu školní speciální pedagog má svou pozici ve školním poradenském pracovišti, je poradenským pracovníkem v rámci školy. Může mít část úvazku také jako speciální pedagog - učitel.

Rozdíl je rovněž mezi školním poradenským pracovištěm, kde ŠSP působí spolu s metodikem prevence a výchovným poradcem, případně školním psychologem nebo sociálním pedagogem a které je součástí školy, a mezi školským poradenským zařízením, které není součástí školy a zahrnuje zmiňovaná externí pracoviště - speciálněpedagogické centrum a pedagogicko-psychologickou poradnu, kde působí především speciální pedagogové, psychologové a sociální pracovníci. Těmto tématům se budeme blíže věnovat v následujících kapitolách. Zaměříme se na školní poradenské pracoviště, jeho členy, legislativní ukotvení, dále pak konkrétně na školního speciálního pedagoga, jeho pracovní náplň a další aspekty týkající se ŠSP.

\section{2 Školní poradenské pracoviště a jeho poslání}

Školní poradenské pracoviště (ŠPP) je v České republice zřizováno jako součást základní, střední nebo vyšší odborné školy. Škola je povinna pracoviště zřídit a provozovat na základě zákona č. 561/2004 Sb., o předškolním, základním, středním, vyšším odborném a jiném vzdělávání (školský zákon), ve znění pozdějších změn, za existenci a činnost školního poradenského pracoviště proto zodpovídá ředitel školy. Smyslem poskytovaných služeb je především vytvoření vhodných podmínek vzdělávání a všestranný rozvoj žáků, včetně zajištění speciálních vzdělávacích potřeb žáků, prevence rizikového chování, kariérní poradenství pro žáky, metodická a další podpora pedagogických pracovníků (Zapletalová, nedat.). Cílem a posláním zainteresovaných specialistů je tedy vytvoření vhodných podmínek pro zdravý vývoj žáků po stránce sociální, tělesné a psychické a rozvoj jejich osobnosti v průběhu vzdělávání. Podílejí se také na rozvoji profesních dovedností pedagogických pracovníků. Jednají také s dalšími institucemi a rodiči. Poradenské služby ve škole jsou podpůrným systémem, jehož cílem je optimalizovat výchovně-vzdělávací proces ve škole i rodině (Novosad, 2009; Čech, 2011a; Pekárková in Mertin et al., 2013).

V našich školách se nachází většinou základní model poradenských služeb. Najdeme zde výchovného poradce a školního metodika prevence. Jedná se většinou o učitele se specializační průpravou v akreditovaném vzdělávacím programu MŠMT pro výkon dané funkce (Kucharská, in Valentová et al., 2013; Kucharská et al., 2013). Začíná se však objevovat čím dál častěji model rozšiřený, kde vedle metodika prevence a výchovného poradce najdeme také další odborníky, které již nenařizuje zákon, a to školního psychologa, školního speciálního pedagoga, případně ve vybraných školách (prozatím sporadicky) sociálního pedagoga. Zastoupení těchto profesí je na jednotlivých školách 
různé, závisí na typu školy, populaci žáků, profesní profilaci odborníků, složení pedagogického sboru apod. Kvalifikační standard poradenských pracovníků ve škole je upraven zákonem č. 563/2004 Sb., o poradenských pracovnících a o změně některých zákonů (novela č. 198/2012). Funkční školní poradenské pracoviště (ŠPP) je předpokladem pro práci školního speciálního pedagoga, který pracuje ve prospěch žáků se speciálními vzdělávacími potřebami (SVP) a žáků s přechodnými problémy (Kucharská et al., 2013). Funkčnost ŠPP podléhá podpoře vedení školy a dobrému odbornému profilu jeho specialistů, jejich zkušenostem a dalšímu prohlubujícímu vzdělávání. Záleží také na atmosféře celé školy. Pakliže není ve škole dobrá atmosféra, mohou být specialisté a jejich činnosti vnímány jako formalita nebo jako jdoucí proti pedagogům. Proto je zásadní podmínkou týmová spolupráce, otevřenost, komunikace všech aktérů školy, ale i subjektů mimo školu (Kucharská et al., 2013).

Jak už bylo řečeno, vytvoření pozice pro školní speciální pedagogy zákon nenařizuje, stejně tak pro školního psychologa ani sociálního pedagoga. Tyto profese však mohou být školám velice nápomocné a užitečné, každý z odborníků školního poradenského pracoviště totiž obrací svou pozornost na určitou specifickou skupinu žáků (Čerstvá \& Čech, 2009). Školy následují nezřídka především vzdělávací funkci a na socializaci a osobnostní rozvoj není kladen vždy takový důraz. Mnohdy je tato role školy podceňovaná, což v kombinaci s oslabováním výchovné role rodiny může mít vážné důsledky. Potřeba, aby někdo tuto roli plnil a vytvářel oporu učitelům ve výchovné funkci, je enormní. Proto je nutné, aby na škole byli odborníci, kteří se budou této problematice naplno věnovat.

Neoddiskutovatelná je bezpochyby role školních psychologů, kteří se zaměřují na řešení individuálních problémů žáků s výchovnými nebo vzdělávacími potížemi nebo sociálním znevýhodněním. Ačkoliv čím dál více škol chápe důležitost této profese a uvědomuje si její přínos, stále je mnoho škol, které tuto potřebu nevnímají a spolupráce s těmito odborníky v nich chybí.

Prozatím stranou většího odborného zájmu je role sociálního pedagoga, ačkoli ho mezi odborníky působícími v rámci školního poradenského pracoviště sporadicky nacházíme. Právě vizí a výzkumným ověřením uplatnění tohoto odborníka ve škole se zabývali mj. Soják a Čech (2010). Autoři vycházejí z mapování situace v podmínkách ZŠ a prokázali jednoznačnou smysluplnost odborného uplatnění zmíněného odborníka ve školním prostředí. V příspěvku Čecha (2007) je vymezena pozice sociálního pedagoga jak ve vztahu k žákům, tak ve vztahu k učitelům a rodičům, ale také z hlediska utváření klimatu školy a fungování školy jako sociální instituce.

Jak je patrné, školní speciální pedagog, školní psycholog, a především sociální pedagog jsou relativně nové profese, které si ještě musí vydobýt své pevné místo ve školách a aktuálně se stále více či méně etablují. A to na rozdíl od výchovných poradců, kteří působí v českém školství již více než půl století, ačkoli náplň jejich odborné funkce prošla v posledních letech zásadními změnami (Růžička et al., 2020). Zatím jsou zmíněné pozice zřizovány spíše 
osvícenými řediteli škol a financovány většinou z nejrůznějších projektů. Školní speciální pedagogové jsou pro školy spíše nedosažitelným přáním nebo přinejmenším aktuální novinkou. Na nedostatečném začlenění ŠSP má z velké části podíl nesystémové financování, které bývalo realizováno projekty VIP 1-3 a v současné době především prostřednictvím šablon a rozvojových programů. Růžička et al. (2020) také upozorňují na fakt, že kvůli této nesystematičnosti není MŠMT ČR schopno doložit, kolik školních speciálních pedagogů skutečně v základním školství je. Způsob financování s sebou nese také rizika a nepř́ijemnosti. Vyplývá z něj nutnost sjednávat pracovní poměr pouze na dobu určitou, což komplikuje strategické plánování organizace, ale přináší rizika i pro pracovníky (nejistá pracovní perspektiva, nemožnost získávat úvěry a hypotéky apod.).

Přínos ŠSP pro školu, žáky a společnost je však nesmírný, protože se zabývají důležitými aspekty, na které bohužel běžný pedagog nemá v edukačním procesu čas. Výzkum realizovaný kolektivem autorů Růžička, Pastieriková, Smolíková, Fialová, Baslerová et al. (2020) dokládá pozitivní posun ve školních poradenských činnostech, ale autoři hovoří také o výrazných rizicích. Zmiňují, že idea rovného přístupu ke vzdělávání je stále vize, nikoliv skutečnost, a jednou z př́ičin proč tomu tak je, je konzervatismus našeho vzdělávacího systému, který neochotně přijímá změny. Nedůvěře k oprávněnosti konceptu společného vzdělávání přispívají také časté změny v legislativních normách, kdy např́klad vyhláška č. 27/2016 Sb. má od roku 2016 šest novel. Legislativa nedává jednoznačné odpovědi na otázky týkající se společného vzdělávání. Autoři hodnotí, že k rovným podmínkám ve vzdělávání je před námi ještě dlouhá cesta.

\section{3 Školní speciální pedagog a jeho role v poradenském systému školy}

Speciální pedagog má v našem školství letitou tradici. Před rokem 1989 se jednalo o speciální pedagogy - učitele, kteří pracovali na základních školách, zejména ve specializovaných a vyrovnávacích třídách a ve školách speciálních. Postupně se role speciálních pedagogů přesouvala od učitele k odborníkovi školnímu speciálnímu pedagogovi. Tato profese zprvu nebyla legislativně ukotvena, její iniciace vyvstala z potřeby denní praxe. Ředitelé reflektovali, že jim školní speciální pedagog (ŠSP) významně vypomáhá se specifickými skupinami žáků, ale také s podporou žáků samotných, dále také s metodickým vedením učitelů, v jejichž třídě se žáci se SVP nacházeli. Tito odborníci dále napomáhali s komunikací s rodiči a dalšími odbornými subjekty mimo školu. Vyhláškou 72/2005 ve znění pozdějších předpisů a Koncepcí poradenských služeb poskytovaných ve škole z roku 2005 (inovovaná v roce 2011), byla pozice ŠSP ukotvena v rámci školního poradenského pracoviště (Kucharská et al., 2013). 
Školní speciální pedagog je, jak už bylo zmíněno, jedním z odborníků, kteří v rozšířeném modelu zajištují činnost ŠPP. Zapletalová (nedat.) definuje nejčastější okruhy práce ŠSP jako koordinaci speciálněpedagogického poradenství ve škole, přípravu a ovlivňování podmínek pro integraci ve spolupráci s dalšími odborníky. Tento proces integrace se sleduje a vyhodnocuje. ŠSP podporuje nejen žáky se speciálními vzdělávacími potřebami, ale poskytuje podporu všem žákům, kteří ji potřebují na základě krátkodobých či dlouhodobých podpůrných opatření. Při vedení dokumentace dbá na ochranu osobních údajů. ŠSP provádí také depistáž - vyhledává žáky se SVP a zařazuje je do speciálněpedagogické péče. Věnuje se také diagnostické a intervenční činnosti v podobě diagnostiky SVP žáka, stanoví individuální plán podpory žáka v rámci školy i mimo ni a intervenční činnost realizuje. Zajistí, či sám realizuje individuální práci se žákem či skupinou žáků - reedukaci, kompenzační a stimulační činnosti, speciálně-vzdělávací činnosti, participuje na vytváření individuálního vzdělávacího plánu (IVP), vyhodnocuje a upravuje navržená opatření, podílí se na úpravách školního prostředí, zajištuje speciální a didaktické pomůcky a materiály, komunikuje s rodinou žáka, zajištuje další služby pro žáka a komunikuje s dalšími odborníky, poskytuje speciálněpedagogické poradenství a intervenci žákům, zákonným zástupcům a pedagogům ve škole, participuje na kariérovém poradenství, připravuje a průběžně upravuje podmínky pro integraci žáků se SVP, spolupracuje se školskými poradenskými zařízeními a jinými institucemi ve prospěch žáka se SVP. Podílí se na tvorbě vzdělávacích plánů a programů školy s cílem zkvalitnit služby a péči o žáky se SVP, provádí metodické činnosti pro pedagogy (návrh metod a forem výuky, instruktáž ve využívání speciálních pomůcek a didaktických materiálů), koordinuje a metodicky vede pedagogické asistenty. Vede dokumentaci a vždy se řídí etickým kodexem poradenského pracovníka. Jeho činnosti se budou lišit v závislosti na konkrétní škole, některé jsou však vykazovány vždy.

Autoři Kucharská et al. (2013) odhadují, že ŠSP bylo v roce vydání jejich publikace přibližně 150. Problémem určení počtu těchto odborníků je, že neexistuje žádný registr a pozice může být financována z různých zdrojů. ŠSP může být zároveň učitel v dané škole nebo může mít část svého úvazku ve školském poradenském zařízení (SPC, PPP), může pracovat jako soukromá osoba (OSVČ) nebo působit v jiném pracovišti. Výše úvazku a počet hodin se může výrazně lišit. Kucharská et al. doporučují minimálně poloviční úvazek, aby se mohl ŠSP se školou sžít a poznal dobře její prostředí, klima, jednotlivé pedagogy i žáky. Autoři také připomínají, že ŠSP mohou být zapojeni do škol díky financování z projektů evropských sociálních fondů. V některých školách jsou zapojováni hlavně do podpory žáků se speciálními vzdělávacími potřebami, pak se jedná o terapeutický model péče.

Perspektivním modelem je práce s podporou všech žáků se SVP a žáků s přechodnými problémy. Rozšiřrený model ŠPP umožňuje realizovat preventivně intervenční model péče. Projekt RŠPP-VIP II ukázal, že rozšířený model péče je velice funkční a že zapojení dalších specialistů ve školách je velmi 
úspěšné (Kucharská \& Toman, 2010; Kucharská et al., 2013). Postupně také došlo k posunu v pojetí služeb od pouhé diagnózy k podpoře všech žáků. V počátcích práce školních speciálních pedagogů, pracovali tito specialisté pouze s identifikovanými žáky se SVP - byla to jasně zřejmá skupina, jejímž příslušníkům již byla stanovena konkrétní diagnóza. ŠSP vnímali, že lze poskytnout podporu žákům nejen přímou činností s nimi, ale také podporou ve třídě, metodickým vedením učitelů a rodičů či podporou ze strany externích odborníků a institucí. Následně si všimli také fenoménu, že včasná intervence u žáků s obtížemi, avšak bez diagnózy, je velice účinná a předchází vzniku větších potíží. „Došlo zde k postupné akceptaci potřeby věnovat se i těmto žákům, mnohdy podpořené dobrou zkušeností při včasné intervenci na půdě školy, kdy se problém žáka podařlo rozpoznat a vhodně intervenovat tak, že k předpokládanému vyšetření v PPP již nemuselo dojít, protože obtíže žáka se zmírňovaly, či dokonce vymizely“ (Kucharská et al., 2013, s. 34). Současné tendence se tedy odklání od pouhé diagnostiky a kategorizace žáků a snaží se o co nejpřesnější popis žákových obtíží, což otevírá možnosti uplatnění školních speciálních pedagogů, jejichž posláním je z důkladné analýzy problému zformovat a realizovat cílenou a včasnou intervenci.

Mnoho otázek ohledně profese ŠSP a jeho náplně práce je stále nejasných. Velmi pokrokové školy zaměstnávaly ŠSP ještě před ukotvením v legislativě. Od té doby jsme zase ušli kus cesty a mnoho otazníků bylo vyjasněno. Zásadní roli hraje vzdělání. Každá profese musí mít stanovené kvalifikační standardy. Dle zákona 563/2004 Sb., o pedagogických pracovnících a o změně některých zákonů, ve znění pozdějších předpisů, získává speciální pedagog odbornou kvalifikaci absolvováním akreditovaného magisterského studijního programu v oblasti věd pedagogických, které jsou zaměřené (a) na speciální pedagogiku nebo (b) zaměřené na předškolní pedagogiku nebo učitelství ZŠ nebo středních škol, ale taktéž zaměřených na přípravu vychovatelů a doplňujícím studiem, které rozšiřuje kvalifikaci a je uskutečňováno vysokou školou. Dále také získává odbornou kvalifikaci ten, kdo absolvuje studium oboru pedagogika a doplňující studium k rozšíření odborné kvalifikace uskutečňované vysokou školou (c). Podle tohoto zákona je speciální pedagog pedagogickým pracovníkem, který koná přímou vyučovací činnost, přímou činnost výchovnou, přímou speciálněpedagogickou činnost nebo také prrímou pedagogicko-psychologickou činnost, a to přímým působením na vzdělávaného jedince, jímž uskutečňuje výchovu a vzdělávání (§ 18 zákona č. 563/2004 Sb., o pedagogických pracovnících).

Kucharská et al. (2013) připomínají, že neexistuje z hlediska úkolů ve vztahu k dětem a jejich rodinám zásadnější rozdíl mezi školním speciálním pedagogem a pedagogem poradenským pracujícím v PPP či SPC. Vyhláška 412 z roku 2006 o dalším vzdělávání pedagogických pracovníků, akreditační komisi a kariérním systému pedagogických pracovníků udává pět kariérních úrovní profese speciálního pedagoga v platové třídě 11-13 s rozsahem předpokládané praxe 0 let v prvním stupni a 5 let v pátém kariérním stupni. 
Autorky dále dodávají, že profesi speciální pedagogů vykonávají taktéž lidé, kteří dokončili před rokem 1989 obory Učitelství či Vychovatelství pro mládež vyžadující zvláštní péči. V dané době svébytný obor Speciální pedagogika neexistoval. Zmiňují také, že z každého typu studia vyplývají určitá omezení a těch by si měl být pracovník vědom a zaměřit se na ně při dalším studiu. Například speciální pedagog - učitel by se měl zaměřit na oblast poradenství a rozšiřit v tomto směru svůj odborný profil, kdežto absolventi speciální pedagogiky oborové budou potřebovat prohloubit své znalosti v oblasti školní didaktiky. Pedagogické fakulty Univerzity Karlovy v Praze a Univerzity Palackého v Olomouci například nabízejí specializační studium školních poradenských služeb, které je zaměřeno na školní speciální pedagogiku. Autorky navíc apelují na to, že je nanejvýš vhodné, aby školní speciální pedagogové, stejně jako školní psychologové, absolvovali sebezkušenostní či psychoterapeutický výcvik, který značně rozširýi profesní rámec zejména při přímých aktivitách se žákem či skupinami žáků, ale také s rodiči žáků. Vhodná je také pravidelná supervize pracovníků.

Pilař (2010) kritizuje české školství za jeho rigiditu a nechut k inovacím. Apeluje na potřebu dalšího vzdělávání pedagogických pracovníků. Přestože Pilař vnímá určitý posun, stále spatřuje prodlevu pedagogů běžných škol v setrvačnosti denní praxe a využívání pouze tradičních pedagogických metod a postupů. Pedagogové odmítají inovace a potřebu individualizace vzdělávání, tím spíše u dětí s postižením či specifickými potřebami učení. Kritizuje také zaměření na výkon a didaktickou složku, a nikoliv na rozvíjení jedinečnosti a osobnosti každého žáka. Tento přístup dle Pilaře (2010) přináší v důsledku neurotizaci dětí, jejich nízké sebevědomí, sebedestruktivní tendence, projevy agrese a selhávání v náročných životních situacích.

Problém neschopnosti přizpůsobovat se vzdělávacím potřebám společnosti a reagovat dostatečně rychle na změny ve všech oblastech lidského života kritizuje i Jirásko, ředitel základní školy a člen rady Asociace ředitelů ZŠ (Učitelské listy, 2018). V polemice, zda je české školství rigidní a svázané tradičními přístupy, uvádí, že i po téměř 250 letech od zavedení povinné školní docházky je české školství stále odrazem doby, ve které vzniklo. Chybějící flexibilita rozevírá nůžky mezi tím, co se děje ve školách a co ve společnosti. V souladu s tvrzením Pilaře (2010) kritizuje Jirásko (2018) školský systém založený na jednotnosti a povinnosti, ignorující svobodu, vlastní rozhodování, různorodost a individuální limity. Oborová struktura je zastaralá a výstupy ze škol jsou podle něj žalostné. Negativně hodnotí také emoční nastavení škol. Panuje zde strach žáků i rodičů, učitelů, ale i ředitelů. Za nejdůležitější prvek považuje učitele, kteří by měli být připraveni na to, že škola má vypadat jinak, než jakou zažili oni. Klade na ně požadavky jako perfektní ovládnutí didaktiky, psychologie a efektivních metod učení nebo schopnost práce s heterogenní skupinou, individualizace výuky a umění správného hodnocení. Dnešní učitel se musí celoživotně vzdělávat a musí být schopen pracovat v týmu. Jirásko ovšem poukazuje také na finanční a společenskou situaci 
pedagogů. Pilař (2010) naopak vyzdvihuje situaci ve školách speciálních či speciálních třídách zřízených v běžných školách. Podle autora se zde velmi dobře daří zavádět nové způsoby vzdělávání jednak díky inovacím vlastním, jednak díky aplikaci výsledků spolupráce se zahraničními kolegy, přičemž Pilař (tamtéž) vyzdvihuje především spolupráci s Dánskem a Německem. Úroveň našich speciálních škol je dle něj vysoká a odborný přístup je často rovnocenný školám členských zemí EU.

Profese školního speciálního pedagoga je podmíněna platnými zákony, vyhláškami a předpisy, které tu již byly vzpomenuty. Taktéž jsme se dotkli nutného vzdělání a kvalifikace i potřeby dalšího vzdělávání. Působení ŠSP je však také ovlivněno osobnostním nastavením a vlastnostmi (Šafrová, in Knotová et al., 2014). Tato pracovní pozice klade mj. značné nároky na komunikační dovednosti. Specialista musí být taktní, musí umět hledat adekvátní řešení a dělat kompromisy. Musí umět dobře vést rozhovor, vyjednávat a mít profesní nadhled a zkušenosti. Kucharská et al. (2013) považují za nevhodné, pokud na místo ŠSP nastoupí čerstvý absolvent. Tato pozice je jedinečná a ve své roli je pak specialista osamělý a nemá se od koho učit. Velmi náročným aspektem pro začátečníka je kvůli věku komunikace s rodiči, ale i s učiteli. Pokud se ve škole pozice ŠSP zavádí nově, je důležité, z jakého důvodu ji ředitel zřídil. Zda se jedná o potřebu této pozice, nebo je to jen formalita. Pokud na školu přichází nový ŠSP, hraje významnou roli, zda na škole mají již nějakou předchozí zkušenost se ŠSP a jaká ta zkušenost je. Problematické může být, pokud do role ŠSP přechází někdo, kdo na škole působil již v jiné roli, třeba jako učitel. Vymezení rozdílů této práce i vymezení pracovních vztahů může být komplikované. Ačkoliv již navázané pracovní vztahy mohou být i velkou výhodou.

Formulace konkrétní koncepce a náplně práce je pak konsensus mezi ředitelem a školním speciálním pedagogem. Odvíjí se od vize ředitele školy, potřeb školy a místní komunity, ale i možností a představ ŠSP. „Profesní vývoj specialisty by se měl odehrávat v intencích potřeb konkrétní školy a [díky] průběžné reflexi těchto potřeb se tak speciálnímu pedagogovi začnou vynořovat další možné pobídky v oblasti jeho profesního rozvoje, které by měl zvažovat jak z hlediska vlastních reálných kompetencí, tak z hlediska vlastních motivací, odborných zájmů, ale i limitü (Kucharská et al., 2013, s. 40). Jak již bylo výše zmíněno, tento specialista může být na škole osamocen, jenže v profesním životě hraje velmi důležitou roli, vedle kariérního růstu a dalšího vzdělávání, také profesní sdílení. Výhodou v tomto směru je, když na škole působí také školní psycholog nebo sociální pedagog, případně pokud by došlo k optimálnímu propojení kompetencí všech tří poradenských profesí. Vzájemné sdílení těmto profesím prospívá a pomáhá jim k pracovnímu růstu. Pocit sounáležitosti k profesní skupině je významný a na důležitosti nabývá, pokud není nasycen. Někteři ŠSP jsou začleněni do celorepublikových projektů, které se také snaží vytvořit a udržovat jistý oborový standard, který by napomohl nově vzniklé profesi se etablovat a ustálit a pomáhal metodicky vést a podporovat jejich aktéry (Kucharská et al., 2013). 
Výše v této kapitole jsme se dotkli významu osobnostních charakteristik. Typ osobnosti je jedním z faktorů, které ovlivňují formu práce a její úspěšnost. Škola je považována za živý organismus, ve kterém se neobejdeme bez empatie, schopnosti spolupracovat a naslouchat, bez týmového ducha, kreativity, schopnosti přijímat inovace, vyjednávat a dělat kompromisy. „Nevhodným partnerem je ten, kdo je moc namyšlen na to, že je považován za vševědoucího, že ho lidé vyhledávají proto, aby jim poradil, protože on zřejmě všem nejlépe rozumí a dívá se na sebe s představou, jaký já jsem mimořádný člověk, že se mi lidé se vším svěřujī“ (Long, 1990, in Křivohlavý, 1993, s. 48). Úlehla (2005) dále konstatuje, že jaký vztah máme ke kolegům, takový vztah máme ke klientům. Rogers (in Křivohlavý, 1993) říká, že člověk, který dokáže naslouchat, projevit porozumění a pochopení, je autentický a je schopen akceptace, ten je i druhými lépe tolerován, akceptován a přijímán a je vnímán jako důvěryhodný nejen ve směru k žákům a rodičům, ale i pedagogům. Je důležité, aby školní speciální pedagog měl zdravě nastavené sebepojetí a byl schopen odpovídající sebereflexe. Pokud máme stabilní sebepojetí, jsme schopni přiměřeně zpracovat nespravedlnost, křivdu a jsme schopni reálně zhodnotit, v čem jsme chybu udělali a v čem ne (Schmidbauer, 2008). Dalšími důležitými vlastnostmi jsou kreativita a flexibilita. Je potřeba překonávat funkční fixaci (přesvědčení, že věci jdou vykonávat jen jedním určitým způsobem). Náplní práce ŠSP je hledání nových cest a dalších způsobů, jak dojít k cíli, a proto musí být také schopen problém najít, nahlížet na něj z vícero úhlů, musí navrhnout a následně realizovat nejlepší možný postup a taktéž musí být schopen zhodnotit postup a jeho efektivitu a případně navrhnout úpravy. Smékal (2007, s. 327) napsal, že „v každé problémové situaci můžeme definovat několik problémů, každý problém má několik řešení a ke každému řešení vede několik cest, přičemž v různých podmínkách nebo u různých řešitelů nemusí být vždy tytéž cesty nejlepšími“.

V pestrosti a rozmanitosti práce však Kucharská et al. (2013) vidí i jistá rizika. Hovoří o tom, že práce ŠSP je velice rozmanitá a pracovník musí být schopen udržet si hranice jak kompetenční, tak časové. Tyto hranice nebývají jasně určené, pracovník si svou činnost řídí sám a korekce od kolegů je minimální. To může způsobit rychlý nástup syndromu vyhoření. Potřeba pomáhat může přerůst i do negativní až fanatické dimenze, kdy pracovník nezná hranice, humor, neptá se po smyslu cíle, ale chce ho za každou cenu dosáhnout (Schmidbauer, 2008). Proto se vracíme zpět k apelu na potřebu dalšího vzdělávání, zvyšování kvalifikace a absolvování výcviků a kurzů nejrůznějšího zaměření v oblasti kompetencí a seberozvoje.

Kucharská et al. (2013), ale i Růžička et al. (2020) upozorňují na fakt, že profese školního speciálního pedagoga je stále se etablující subprofesí. Kucharská et al. (2013) píší, že kompetence nejsou ve všech aspektech ještě zcela jasně uchopitelné a vzniká mnoho nejasností ohledně kompetencí ŠSP nejen z pohledu samotného pracovníka, vedení, ale i z pohledu dalších profesí a institucí, které jsou se školním speciálním pedagogem ve vztahu. Rưžička 
et al. (2020) již s několikaletým odstupem uvádí, že učitelé i ŠSP se shodují v činnostech, jež by měli školní speciální pedagogové plnit, a to především v oblasti spolupráce s učiteli a rodiči. V tomto směru Kucharská et al. (2013) i Růžička et al. (2020) zmiňují tzv. negativní kompetence, tedy kompetence, které patří někomu jinému. Práce s kompetencemi, práce s časem, ale také oddělování pracovních záležitostí od soukromých jsou součástí profesionality. Pro zachování nadhledu a odstupu musíme neustále reflektovat naše potřeby a hranice a ptát se na smysl cíle, který jsme si stanovili. Rozmanitost našeho vnitřního nastavení reprezentuje hranice v př́stupu ke klientům, at' už jde o míru formálnosti, direktivity nebo aktivity, či dimenze úkol-vztah (Timulák, 2005).

Profesní sebeobraz odráží vnímání své pracovní pozice v systému školy, stejně tak vnímání nároků na pracovní výkon. Kategorie jako tvořivost, seberozvoj a samostatnost bývají vnímány jako motivace a pohnutka pro setrvání v dané pozici. Nevýhodami jsou naopak horší možnosti pro profesní sdílení, nejistoty ve financování, neetablovanost profese, nejasnosti v užívání diagnostických materiálů a nejasnosti v očekávání. Novost profese však může být vnímána i jako výzva a motivace, nejen jako zátěžový faktor (Kucharská et al., 2013).

\section{4 Školní speciální pedagog ve vztazích}

Pozice školního speciálního pedagoga je v systému školství relativně nová. Tak jako každá jiná profese, nese i tato svou určitou roli a status. Autorem těchto pojmů je R. Linton (Výrost \& Slaměník, 2008), který pod pojmem status viděl pozici člověka ve společnosti a aktivní stránku daného statusu Linton nazývá rolí. Je to tedy standard chování, který od jedince určitého statusu legitimně očekáváme a vyžadujeme. Role korigují naše chování v sociálních pozicích - očekává se od nás určité chování, my toto očekávání vnímáme, interpretujeme jej a převádíme do rolového chování. Role však neovlivňují pouze naše chování, ale také názory, postoje a hodnoty (Nakonečný, 1997; Jandourek, 2001; Matoušek, 2008; Výrost \& Slaměník, 2008; Špirudová, 2015). Linton (dle Výrost \& Slaměník, 2008) rozděluje statusy/role na vrozené (pohlaví), připsané (věk), získané (vzdělání, profese) a Keller (2005) ještě přidává status vnucený, kterým je např́klad povinná vojenská služba nebo nezaměstnanost. Profese je významným faktorem k posuzování statusu jedince. Dospělý jedinec je posuzován podle toho, jakou profesi vykonává, mladý člověk dle profese, kterou bude pravděpodobně zastávat, na kterou se připravuje. Ztráta profesní role (nezaměstnanost, stáří) často způsobuje ztrátu statusu a následně izolaci. Výkon určitých profesí přináší moc, příjem a prestiž (Keller, 2008). Podle Matouška (2008) mohou role s sebou nést i konflikty. Více rolí zastávaných jedním člověkem může být v konfliktu (kariéra vs. matka), 
konflikt však může být i uvnitř pouhé jedné role. Každá role je spojena také s emocemi a prožíváním.

V rámci profese školního speciálního pedagoga se taktéž očekává určitý standard chování - profesní role, která je užším vymezením role sociální -, je to soubor názorů a postojů společnosti, ale i jednotlivce $\mathrm{k}$ dané profesi. Hodnocení role může být z pozice interní (interní image profese) nebo externí, pokud nejsme nositelem této role - nejsme školním speciálním pedagogem, ale jsme třeba jeho klienty. Pak se jedná o externí image profese (Špirudová, 2015). Externí image bývá často konstruktem médií a bývá stavěna do extrémně pozitivní nebo extrémně negativní polohy, což může ve výsledku negativně ovlivňovat práci těchto profesionálů a přístup klientů k dané službě.

Školní speciální pedagog zastává ve své profesi mnoho rolí. Je poradcem, koordinátorem, je to osoba, která vede, plánuje a dohlíží na průběh a výsledky naplánovaných činností. Je také kolegou, podřízeným, zprostředkovatelem služeb, odborníkem aj. Široký záběr je dán tím, že profese není ještě zcela etablovaná, konkrétní náplň práce je konsensem mezi ním a zaměstnavatelem, ale také je to dáno tím, že působí v široké oblasti při práci s žáky, rodiči, pedagogy a institucemi. Pracovník musí být v přechodu mezi rolemi flexibilní. Jinak bude vystupovat při jednání s žákem, jinak s pedagogem a jinak při jednání s rodičem žáka.

Očekávání vedení školy, ale i klientů (rodičů, pedagogů) vůči ŠSP může být i nereálné a naivní. ŠSP je specialista, odborník, ale není všemocný ve schopnosti reagovat na všechny potřeby a změny, které potřebují čas. Nemůže být kompetentní okamžitě řešit všechny problémy, nebot' jejich náprava není okamžitá a vyžaduje spolupráci všech zúčastněných. Mnozí pedagogové si myslí, že pokud předají dítě do péče školního speciálního pedagoga, tím jejich práce končí a dále nenesou žádnou zodpovědnost za jeho vzdělávání. Pokud mají učitelé a vedení nereálné představy, brzy mohou dojít k přesvědčení, že se jejich očekávání nenaplní, a mohou mít pocit, že je profese ŠSP zbytečná, nefunkční a že se věci nezlepšují a nikdy zlepšit nemohou, a v profesi ŠSP se zklamou. Je výhodou, když je ředitel znalý legislativy ve věci školního speciálního pedagoga a ideálně se obrátí na další školy, kde je již tato pozice úspěšně zavedena. Při zavádění ŠSP do školy je třeba si ihned v začátcích vyjasnit vzájemná očekávání ŠSP a vedení školy - má být ŠSP odborným konzultantem pro rodiče, žáky, učitele? Je partnerem vedení školy případně učitelů, nebo je metodik a vzdělavatel pedagogů a rodičů? Má být spolu s výchovným poradcem a metodikem prevence koordinátorem odborných aktivit ŠPP? Jaké jsou jeho kompetence a náplň práce, včetně časového ohraničení? Jaký bude jeho vztah vůči škole a dalším institucím, jako je např́klad PPP, SPC, OSPOD? Ve většině případů vedení školy vnímá ŠSP jako přínos, avšak mnozí pedagogové ŠSP odmítají, protože si myslí, že náplní jeho práce bude je hlídat a kritizovat a budou se mu muset zodpovídat. Často jsou učitelé v opozici a odmítají se školním speciálním pedagogem spolupracovat. Tato situace však často plyne z neznalosti. V takovém případě je vhodným postupem 
osvěta - vyjasnění toho, co je v náplni práce ŠSP, jaké jsou jeho kompetence a že jeho prací není kontrola pedagogů, ale naopak, že ŠSP je kolegou, který má společný cíl. Kucharská et al. (2013, s. 61) píší, že „není cílem školního speciálního pedagoga měnit školu a učitele v ní, ale citlivě nabízet možnosti s respektem $k$ limitům učitelů a s vědomím, že i on sám je v něčem limitován“.

Na otázku, zda má být ŠSP vůči učitelům odborníkem, nebo kolegou, odpovídají zmínění autoři tím, že každá vyhraněná pozice je nevhodná. Je-li ŠSP pouze odborníkem a nepovažuje pedagogy také za odborníky, je jeho pozice expertní a př́stup nevyrovnaný. Nicméně pokud je ŠSP pouze kolegou, i tento vztah může být problematický, protože jeho role je od učitele odlišná. Speciální pedagog by měl dle Kucharské (2013) stát uprostřed. Někdy spolupracuje jako rovnocenný kolega, jindy poskytuje ŠSP učiteli oporu ve smyslu emocionální podpory, motivace a profesního sdílení nebo cílenou metodickou podporu, vedení, vzdělávání, realizuje intervence i přímou práci se žákem. ŠSP by měl být také schopen analyzovat možnosti a limity učitelů s ohledem na jejich třídy (složení, počet žáků, charakteristika žáků aj.) a podle toho jim pomáhat zvládat výchovně vzdělávací proces či jednání s rodiči.

Již jsme zmínili vztah s vedením školy i s pedagogy. Významným vztahem je také vztah školní speciálního pedagoga a žáka. Tento vztah ovlivňuje velikost a atmosféra školy, angažovanost školního speciálního pedagoga, ale také osobnost žáka i osobnost ŠSP. Všichni zúčastnění však musí mít na paměti, že ač může vztah být velice podporující, plný empatie a vřelosti, stále je to vztah profesionální a je potřeba ctít hranice. ŠSP není ani rodičem, ani kamarádem. Jeho působení má omezený vztahový a časový prostor. ŠSP má dítěti pomáhat a podporovat ho, ale musí mu dát také prostor a ve správný čas jej opustit. Dítě by se mělo naučit zdravě se vztahovat k dospělé nerodičovské autoritě. ŠSP musí mít na paměti, že ne vždy je možné vytěžit pro dítě maximum a že ne vždy se dítěti zavděčí. Taková snaha by spíše sytila osobní potřeby pracovníka, nikoliv profesionální a dítěti by taková zkušenost ve vztazích k okolnímu světu neprospěla. ŠSP si musí udržet své hranice mezi profesí a osobními záležitostmi. Vztah ŠSP-žák je rovnocenný vztahu pracovník v pomáhajících profesích a jeho klient. O komplikovanosti takového vztahu již bylo napsáno mnohé a vždy se apeluje na potřebu striktního dodržování hranic. Příkladem je článek Liškové, vedoucí online služeb Linky bezpečí (2015), dále Kopřiva (2013), Cooper (2012), Nedělníková (2008), Etický kodex sociálních pracovníků ČR (2006), Musil (2006), Matoušek (2003), Reamer (2003) aj. ŠSP musí zvažovat hranice zejména u dětí s citovou deprivací, které samy zvyšují intenzitu kontaktu. Zejména v tomto případě je nutné stanovit jasné časové ohraničení a důsledně dbát na jeho dodržování. Ve smluvený čas, který ŠSP má vyhrazený pro dítě, nesmí být nikým rušeni a musí se ŠSP věnovat pouze dítěti, aby dítě vědělo, že i přes krátký časový limit je tu ŠSP jen pro něj. Dítě si pak odnese zkušenost, že i přes krátký časový úsek, který mu byl věnován, se může na dospělého spolehnout a nasytit potřebu jistoty a bezpečí. Co se týče vytvoření zakázky, většinou je iniciátorem učitel, 
případně vedení školy nebo rodič, ale může to být i samotné dítě. V kontaktu s dítětem musíme vždy bezpodmínečně pamatovat na etickou stránku, jelikož se jedná o žáky nezletilé. Proto podléhá kontakt se žákem informovanému souhlasu rodičů či zákonných zástupců (Kucharská et al., 2013).

Rámec rodiny patří také do vztahů školního speciálního pedagoga. Je velmi důležité navázat kladný vztah s rodiči a spolupracovat s nimi, protože jejich účast na řešení potíží žáka je nezbytná. Rodiče, spolu s žákem, učiteli a vedením školy, jsou taktéž klienty ŠSP, i když najdeme variabilitu přístupů jak ze strany ŠSP, tak ze strany rodičů. Tyto přístupy obvykle zrcadlí jejich osobnostní charakteristiky, zkušenosti individuální, rodinné i celospolečenské a odráží také profesní vlivy nebo vliv médií. Ze sondy, kterou provedla Kucharská a její kolegové (2013) vyplynulo, že vztah ŠSP-rodič je víceméně kladný z obou směrů. Rodič hledá oporu a pomoc, radu, alternativu a vyžaduje důvěru. Může ale také vyvíjet na ŠSP tlak ve smyslu negativních kompetencí a zde je na místě, aby ŠSP objasnil možnosti své práce, co může rodiči a jeho dítěti nabídnout, aby vyjasnil vzájemná očekávání a nastavil hranice. Často také ŠSP působí jako mediátor mezi učitelem a rodičem. Může nastat i situace, kdy rodič vnímá spolupráci se ŠSP jako potvrzení problému a odmítá jej. Dalším specifikem jsou pak různé typy rodičů (romské etnikum, cizinci, výkonově orientovaní rodiče aj.). Odborník by se měl dobře zaměřit na očekávání rodičů, měl by je zjištovat a reflektovat a neustále vyjasňovat a usměrňovat, pokud nejsou očekávání rodiče reálná. Dalším zásadním jevem, který ovlivňuje spolupráci ŠSP a rodiče je vztah rodiny a školy. Rodiče vnímají školního speciálního pedagoga v kontextu školy a zkušeností se školou, učitelem či jinou institucí (např́iklad SPC, PPP); z této perspektivy může pracovník jen těžko vystoupit. Pokud jsou předchozí zkušenosti rodiče se školou spíše negativní a komunikace byla pouze v duchu výčitek, obviňování a tzv. „povolání na kobereček“, kdy se rodič cítil ohrožený, ponížený a zneuznaný, pak rodič mnohdy není motivován ke spolupráci a nevidí možnost konstruktivní spolupráce. Matějček (1992) připomíná, že rodičovská identita má být povznášena, nikoliv ponižována.

Škola vnímá rodiče třemi způsoby (Docking, 1990): rodič jako problém, rodič jako klient nebo rodič-partner. Způsob vnímání rodičů školou ovlivňuje jejich vzájemnou spolupráci. V tomto směru může školní speciální pedagog působit jako prostředník. Tam, kde je rodič vnímán jako problém, jako osoba zodpovědná za všechny problémy dítěte, která péči o dítě zanedbává a neplní dobře své rodičovské povinnosti, tam je často také představa, že dokud se nezmění rodina, nezmění se ani dítě a jeho situace. Zajištění této změny pak škola požaduje mj. od ŠSP, což je požadavek nereálný. Z nepřijetí tohoto závazku může dojít i k nedorozumění mezi školou a ŠSP. Problematickým přístupem může být i vnímání rodiče jako klienta. Takový rodič si často školu vybírá sám dle svých představ a zájmů dítěte, rodiči je umožněna participace na vzdělávacím procesu. Někdy však bývá narušeno rovnoprávné postavení obou stran a rodič může mít pocit, že jakožto klient má mnoho práv a opomíjí 
své povinnosti vůči škole, požaduje zajištění změny u problému dítěte a klade odpovědnost za tuto změnu pouze škole a vyžaduje změny bez své vlastní iniciativy a spoluúčasti. Kucharská et al. (2013) vidí ideální stav v partnerství školy a rodiny. Takový přístup vyžaduje oboustrannou zodpovědnost, ochotu a schopnost spolupráce. Strany mají obvykle odlišné zkušenosti a úhel pohledu na dítě a jeho problém, avšak tento vztah není o tom přesvědčit protistranu o své pravdě, ale jde o to, najít společnou cestu a spolupracovat, aby všichni došli ke společně stanovenému cíli, čímž je zejména pomoc dítěti a nalezení nejvhodnějšího řešení v problémové situaci.

Spolupráci mezi ŠSP a rodiči ovlivňují sami pedagogové, jednak tím, jak se staví k problému dítěte, jak vnímají rodiče, ale také jak přistupují k samotnému ŠSP. Pokud má učitel obavy, že jej bude ŠSP kritizovat a zpochybňovat jeho pedagogickou zdatnost či jeho přístup k žákům, nebo pokud nemá učitel jasno v kompetencích ŠSP (které na rozdíl od kompetencí školního psychologa nejsou tak snadno čitelné), mohou pedagogové rodiče od spolupráce se školním speciálním pedagogem odrazovat. Toto může vyřešit první kontakt ŠSP s dítětem a rodinou už při zápisu dítěte do školy, dále pak vlastní prezentace ŠSP na třídních schůzkách, kdy sám zpraví rodiče o tom, kdo je, co je jeho náplní práce, co od něj mohou očekávat, a co naopak ne a co jim jako odborník nabízí. Aby učitel podporoval spolupráci rodiny a specialisty, je nutné, aby tohoto specialistu i učitel vnímal jako partnera. Musí vzájemně respektovat své profese a navodit vztah založený na profesní důvěře (Zapletalová, nedat.).

Nakonec i sám školní speciální pedagog ovlivňuje svou osobností a profesním nastavením spolupráci s rodiči. Každý odborník je jiný v míře direktivity, důraznosti, ne/formálnosti a komunikačních dovedností i v tom, jak vystupuje před rodiči - jako odborník, který ví všechno a radí, nebo je spíše mediátorem a partnerem v hledání řešení a vhodných přístupů k dítěti. Liší se také v míře aktivity a nasazení pro řešení a zvládnutí úkolu, ale i v míře očekáváné aktivity ze strany rodičů. Lišit se odborníci mohou také v nastavení, zda se zaměřují spíše na úkol a jeho striktní vyřešení, nebo je pro ně prvořadý vztah s klientem (rodičem/dítětem), jeho bezpodmínečné přijetí a navození důvěrného vztahu. Odborník musí být schopen „diagnostikovat“ rodiče a flexibilně volit nejvhodnější přístup. Jinak bude přistupovat k výkonově nastavenému rodiči, jinak k rodiči náležícímu k etnické menšině, jinak k volnomyšlenkáři a ještě jinak k rodiči hyperprotektivnímu, úzkostnému apod. Výchozím bodem vztahu je ale vždy očekávání, se kterým rodič za specialistou přichází, a míra spolupráce mezi nimi. A stejně jako u kontaktu s dítětem, i zde platí, že je nezbytné jasné nastavení hranic a jejich striktní dodržování, ale také realistické zhodnocení a reflektování vlastních profesních hranic a kompetencí. Pokud specialista shledá, že je potřebný pro dítě jistý druh intervence, kterou není schopen sám poskytnout, je jeho povinností tuto informaci rodičům adekvátně sdělit a doporučit jinou instituci nebo zařízení, na které se mohou rodiče obrátit, případně může ŠSP rodiči nabídnout pomoc se zajištěním této služby. Kucharská et al. (2013) doporučují zavedení portfolia kontaktů 
na možné odborníky, se kterými lze navázat spolupráci, z nichž se nejčastěji jedná o psychology a psychiatry, neurology, logopedy, rehabilitační a sociální pracovníky.

Školní speciální pedagog je významnou osobou, která se podílí na vytváření funkční vztahové sítě mimo školu, která může podpořit působení školy. Komunikace s institucemi mimo školu nemusí být pouze záležitostí ŠSP, vždy záleží na dohodě a rozdělení kompetencí. Správné delegování komunikace s vnějšími subjekty může předejít zmatkům v komunikaci a ztrátě informací.

ŠSP jedná především se školským poradenským zařízením. Školské poradenské zařízení (ŠPZ) a školní poradenské pracoviště (ŠPP) by měly být odbornými partnery a měly by dobře spolupracovat. Dle Kucharské a Hönigové (2010), jež předkládají metodickou zprávu č. 6 z projektu RŠPP-VIP II, spolupracuje ŠPP nejvíce s pedagogicko-psychologickými poradnami, a to až z $89 \%$. V 78\% to pak jsou SPC a pouze 0,5\% SVP. Sonda přinesla pozitivní zjištění, že spolupráce mezi těmito odborníky je v pouhém jednom procentu problémová a jen v 10 \% je pouze formální. V 65\% je spolupráce dobrá. Spolupráce má podobu konzultací, vzájemného podávání informací a doplňování anamnestických údajů a předávání dílčích výsledků vyšetření. Společně také vyhodnocují individuální vzdělávací plány nebo vypůjčují diagnostické nástroje. ŠPZ pravidelně navštěvuje školu. Faktorem, který ovlivňuje kvalitu spolupráce ŠPP a ŠPZ, je délka spolupráce a stabilita obou pracovišt'. Často bývají pracovníci ŠPZ metodiky pracovníků školního poradenského pracoviště. Otázkou spolupráce odborníků se zabývá také Rưžička et al. (2020). Spolupráce se ŠPZ je podle autorů pro školní speciální pedagogy nezbytná. Řeší IVP, navržení podpůrných opatření, administrativu, problémové situace a intervenční strategie. Autoři dále ve svém výzkumu píší, že pracovník ŠPZ navštěvuje školu nejčastěji jednou za měsíc, mnohdy je spolupráce založená na komunikaci elektronické či telefonické.

Další spolupráce je na úrovni místní a státní správy. Škola je instituce, která ovlivňuje dítě, formuje jeho osobnost, hodnoty, postoje a názory, připravuje ho na život ve společnosti. Pro efektivní plnění těchto cílů se musí sama škola zapojovat do komunitního života. Škola, která nabízí vzdělávací, kulturní, sociální a rekreační program, podporuje celoživotní vzdělávání všech členů komunity, má především preventivní charakter. „Komunitní škola může lépe reagovat nabídkou svých služeb na potřeby svých žáků a jejich rodičů v souladu se společenskými proměnami a státní zakázkou“ (Kucharská et al., 2013, s. 95). ŠPP může být iniciátorem takového širšího pojetí koncepce školy, a tím se školní speciální pedagog, potažmo všichni členové ŠPP, podílí na vytváření image školy. Avšak celkové převzetí plnohodnotné funkce koordinátora komunitní školy školním speciálním pedagogem není možné. V takovém případě by se jednalo o kumulaci funkcí, která by bezpochyby vedla ke snížení kvality výkonu v obou rovinách.

ŠSP v rámci své specializace může dále jednat se školským odborem dané městské části, se zřizovatelem, vyhledává granty a zpracovává žádosti o ně, 
může komunikovat také s médii, skrze která prezentuje školu a školní poradenské pracoviště a působí na úrovni osvěty, kdy podává informace a zvyšuje povědomí veřejnosti o aktuálních trendech a problematikách. Spolu s metodikem prevence a výchovným poradcem jedná ŠSP se sociálním odborem městské části či obce. Zde je pro kvalitní spolupráci potřeba vzájemný respekt a pochopení, odborná erudice a vzájemná informovanost. Vhodné je navázání osobního kontaktu, zejména s pracovníky OSPOD. Kucharská et al. (2013) považují za nutné, aby ŠSP byl seznámen i s dalšími zákony, které se netýkají přímo jeho působení, a to zejména s těmito: zákon č. 94/63 Sb., o rodině (který byl nahrazen zákonem č. 89/2012 Sb., občanský zákoník), zákon č. 359/1999 Sb., o sociálně-právní ochraně dětí, zákon č. 47/2019 Sb., kterým se mění zákon č. 108/2006 Sb., o sociálních službách, ve znění pozdějších předpisů a zákon č. 111/2006 Sb., o pomoci v hmotné nouzi.

Kucharská et al. (2013) dále připomínají nutnou spolupráci s Policií ČR a městskou policií, a tudíž nutnost seznámení se se zákonnými předpisy, platnými postupy a navázání profesního kontaktu. Dále také ŠSP spolupracuje se zdravotnickými institucemi, které však zatím nejsou př́liš zvyklé spolupracovat se školou. V neposlední řadě je důležité navázat vztah s neziskovými organizacemi, kam patří občanská sdružení, nadace, nadační fondy a obecně prospěšné společnosti, případně příspěvkové organizace, církve či veřejnosprávní instituce. Spolupráce může velmi významně obohatit práci školy s dětmi se SVP a s dětmi v riziku selhání. Kucharská (tamtéž) zmiňuje děti ze sociokulturně znevýhodněného prostředí, děti z rizikového rodinného prostředí, děti se zdravotním znevýhodněním a postižením. Zde jsou často aktivními partnery i rodiče. Výhodou neziskových organizací je přátelské a neformální prostředí. Úkolem ŠSP je zmapovat sít neziskových organizací a vytvořit portfolio. Tyto neziskové organizace působící v jeho spádové oblasti pak bude mít stále při ruce a může se na jednotlivé organizace v prrípadě potřeby obrátit nebo může zprostředkovat kontakt rodině.

V závěru kapitoly se podíváme ještě na jeden významný vztah, a to vztah školního speciálního pedagoga k sobě samému. ŠSP musí být zodpovědný nejen ke svým klientům, ale také sám k sobě ve smyslu prevence syndromu vyhoření, mapování vlastních možností a osobnostních charakteristik, reflektování sama sebe v profesionálním vztahu odborník-klient. Úlehla (2005) píše, že do profesionální práce promítáme svůj přístup k lidem a k životu. To, co si myslíme o světě a o lidech, ovlivňuje naši práci. Úlehla (tamtéž) doporučuje zkoumat sám sebe, naše potřeby a motivaci k práci, protože je přesvědčen, že jaký máme vztah sami k sobě, takový vztah máme i ke klientům. Dostatečným motivem pro práci není jen potřeba pomáhat. Autor nabádá také k reflexi méně povznášejících motivů a potřeb, jako je např́klad mít nad někým moc a smět ovlivňovat životy druhých. Nepřiznání takových tendencí je dle autora nebezpečné nejen pro pracovníka, ale i pro klienta. Pro reflexi, proč pracovník svou práci dělá (ale i jiné otázky), jak už bylo napsáno výše, je pak vhodné absolvování sebezkušenostního výcviku, psychoterapie nebo 
pravidelná supervize. Janáčková (in Weiss, 2011) hovoří, ač na poli medicíny, obdobným způsobem a je přesvědčena, že sebepoznání ulehčuje práci s klientem/pacientem. Autorka upozorňuje na to, že každý zdravotník, v našem případě pedagog nebo také pracovník v pomáhajících profesích, by měl znát svou osobnost a sklony k jednání a své vlastní tendence k posuzování lidí. To může napomoci k vyvarování se chyb. Nelze však opominout ani potřeby fyzické a zajištění kladných podmínek pro výkon profese. Ač se to zdá jako banalita, je to téma více než aktuální. Autor Honzák (in Weiss, 2011, s. 72) pojednává o tématu „služby až do roztrhání těla“ všeříkající humornou historkou, kdy americký psychiatr H. S. Sullivan potkal na chodbě začínající lékařku a tázal se jí, zda byla na obědě. Nadšená mladá lékařka odvětila, že ne, protože nemá čas a musí se postarat o pacienty. Načež se na ni šéf rozkřikl: „Tak to mi řeknete ještě jednou a máte padáka! Protože doktor, který se neumí postarat sám o sebe, neskýtá záruky, že se postará o pacienty. "Pozitivní vztah k sobě samému a osobní psychohygiena jsou klíčovými aspekty pro výkon profese školního speciálního pedagoga. 


\section{Stres a další zátěžové faktory v práci školního speciálního pedagoga}

V návaznosti na závěr předchozí kapitoly se budeme nyní podrobněji věnovat jednomu významnému vztahu, a to vztahu k sobě samému. V současné době, kdy se více věnujeme kariéře a méně našim vztahưm, je to ten nejdůležitější, na který velmi často zapomínáme. Pečujeme o vše možné - o naše děti a blízké, bydlení, oblečení, psa, květinu na okně, ale zapomínáme pečovat sami o sebe a o svou vnitřní pohodu. Stále spěcháme, tlačí nás termíny a požadavky okolí. Pokud nejsme v harmonii sami se sebou, nemůže být harmonický ani náš pracovní život a vztahy s okolím.

Pracovní život je pro člověka velmi důležitý. Připravujeme se na něj již od dětství a stejně jako v dětství hra, tak v dospělosti zabírají pracovní povinnosti podstatnou část našeho dne a stávají se dominantní aktivitou. Proto je potřeba, abychom se i v práci cítili dobře. Práce by nás měla rozvíjet, měli bychom z ní pocitovat naplnění. Profesní život je prostor pro seberealizaci, která nám pomáhá umístit se ve společenství, najít své postavení a dosáhnout určité prestiže ve společnosti. Umožňuje nám zažít úspěch a najít smysl života. Skrze práci naplňujeme naše sny a životní cíle, budujeme si důstojný život ve společnosti, máme pocit společenské prospěšnosti, začleňujeme se do řádu sociálních vztahů. Práce uspokojuje potřebu sebeuplatnění, ctižádosti a sebeúcty. Každý jedinec si během života osvojuje také vztah k práci, který je subjektivním odrazem pracovní pohody, či naopak nepohody. Jsou-li uplatňovány osobní kladné vazby, může jedinec v práci nalézt uspokojení, práce se může stát důležitým prvkem rozvíjejícím osobnost daného jedince a může být zdrojem seberealizace. Duševní rovnováha s prací úzce souvisí - skrze práci můžeme mnoho získat, ale také ztratit, pakliže se stane jedinou náplní našeho života. Zasvětit svůj život pouze práci a očekávat, že naplní náš život a dá mu smysl, je krátkozraké a vysoce rizikové. Lidé, kteří vstupují do světa práce s velkým nadšením a dávají do profesního života vše, mohou často velmi rychle dojít k frustraci a vyhoření (Buchtová et al., 2002; Vágnerová, 2004; Křivohlavý, 2012; Lemrová \& Dobešová Cakirpaloglu, 2016).

Motivace k práci má různé zdroje. V první řadě je to potřeba materiálního zajištění. Finanční ohodnocení umožňuje jedinci podílet se na spotřebě, umožňuje mu nezávislost, samostatnost, ale také smysluplné trávení volného času. Práce přináší jedinci nové možnosti a otevírá budoucnost (Vágnerová, 2004). Ačkoliv může být práce někdy zatěžující, má důležitou roli, protože strukturuje jedinci 
čas, formuje jeho volní vlastnosti, dává jeho životu smysl a řád (Giddens, 1999). Abychom se vyrovnali s pracovní zátěží, je potřeba mít určitou míru schopnosti adaptace. Jak na nás pracovní zátěž působí, je do značné míry otázka našeho nastavení, osobnostních charakteristik, míry frustrační tolerance a v neposlední řadě zkušeností (Křivohlavý, 2012; Paulík 2012; Cakirpaloglu et al., 2015).

Nikdo zřejmě nebude zpochybňovat, že profese pedagoga je velmi náročná a zátěžová. Učitelé nejsou zatížení pouze výukou, ale doléhá na ně i celá škála stresorů a problémů, které musí pedagogové řešit a vyrovnávat se s nimi (Buchwald, 2013). Aby pedagog lépe zvládal stresové záležitosti, klade se velký důraz na osobnostní charakteristiky. Teoriemi stresu se zabývá mnoho autorů z mnoha různých pohledů. První teorie Hanse Selyeho, který definuje stres jako nespecifický stav organismu, který je vyvolaný nároky kladenými na jedince, byla zaměřená primárně na fyziologické projevy. Kognitivními aspekty se začal zabývat Lazarus a respektoval kognitivní i konativní hlediska stresu a také ta emocionální. Slovo stres jsme přejali z aglického „stress“ (napětí, zátěž, síla, tlak), které má svůj původ v latině ve slově „stringere“, tedy utahovat, sevřít (Grofová \& Černý, 2015).

Stres tu není sám od sebe, sehrával důležitou roli v přežití člověka, má nás chránit. Je to automatická reakce - v případě ohrožení člověka spouští poplašný systém a biochemické procesy, aktivizuje nás, posiluje soustředění, aby tím zvýšil naše šance na přežití. Hned jak tělo zaregistruje ohrožení, posílá informaci mozku a ten vyšle do těla endorfiny, látky potlačující bolest. Vedle endorfinů mozek vysílá také kortizol, adrenalin, noradrenalin a tyroxin, látky, které ovlivňují tělesné funkce. Objevuje se pak např́klad bušení srdce, napnutí svalů, zrychlený dech, pocení a mnohé další fyzické projevy. Ovlivněn je také vegetativní nervový systém, který je na naší vưli zcela nezávislý. Reakce na stres, případně na stresory, není u všech stejná, co jednoho stresuje, je pro druhého normální situací. Fyzických projevů reakce na stres je velká škála. V reakcích záleží na předchozí zkušenosti, na odolnosti, na osobnostních charakteristikách, ale i na našich hodnotách, motivaci a cílech. Švingalová (2006) uvádí, že stres je odpověd' organismu na zátěž (stresory), která narušuje normální fungování organismu. Pokud se jedinec domnívá, že je vystaven nárokům, které není schopen zvládnout, nemá dostatečnou adaptační kapacitu a je vystaven stresu. Z toho vyplývá, že důležité je subjektivní emoční a kognitivní zpracování dané situace, tedy to, zda konkrétní jedinec vnímá situaci jako stresovou, náročnou, zátěžovou. Proto je také důležité zvyšovat svou frustrační toleranci, a proto jsou kladeny tak vysoké nároky na osobnost pedagoga. Je nutné, aby jedinec pracující ve stresujících profesích byl schopen nároky profese dobře zvládat a měl vysokou míru odolnosti. Se stresem to navíc není tak jednostranné. Můžeme ho rozdělit na eustres a distres (případně hypostres a hyperstres), tedy stres, který je v určité míře pozitivní, a ten, který je negativní a škodlivý. Fontana (2016) píše, že stres je požadavek na adaptivní schopnosti těla a mysli. Pakliže jsme schopni svými adaptivními schopnostmi vnější nároky zvládnout, může být stres vnímán 
jako pozitivní, užitečný, posilující, motivační a zvyšující výkon. Pokud nároky nejsme schopni zvládnout, jsou nad naše síly, je stres nežádoucí a škodlivý. Stres je přirozenou součástí našich životů a bude vždy přítomný. Proto je potřeba, aby si každý osvojil prvky psychohygieny a copingových strategií (Dobešová Cakirpaloglu \& Čech, 2019).

\subsection{Psychohygiena a pedagogická profese}

Pokud se zabýváme stresory a dalšími zátěžovými činiteli v profesi školního speciálního pedagoga, je třeba zmínit také možnosti podporující jejich předcházení a aspekty formování vnitřní rovnováhy. Jejím hledáním a utvářením se zabývá psychohygiena. Bedrnová (1996) chápe psychohygienu jako hledání vlastní životní cesty a efektivního způsobu žití. Za základní oblasti psychohygieny definuje Křivohlavý (2001) růst osobnosti a sebevýchovu, vnitřní klid, sociální vztahy a péči o prostředí životní a pracovní. Cílem psychohygieny je udržení člověka ve stavu pohody, předcházení nemocem, zejména duševním, taktéž je cílem zvyšování resilience, odolnosti vůči stresu a nepříznivým podmínkám. Vzhledem k tématům, kterými se psychohygiena zabývá, má tento obor velice blízko k vědám lékařským, psychologickým a sociálním. Křivohlavý (tamtéž) dále pojímá psychohygienu jako realistické vnímání světa, adekvátní reakce na podněty, schopnost efektivně řešit úkoly a neustálé úsilí na osobnostním rozvoji. Realistický pohled, zejména na sebe sama, zdůrazňuje také Míček (1984) a říká, že je to dobrý předpoklad pro duševní zdraví. Dalšími předpoklady pro duševní zdraví jsou dle autora vědomá práce na osobnostním růstu a seberealizace. Taktéž je velice důležitá integrita člověka, autonomie a sebeurčení, schopnost definovat vlastní kritéria a měřítka a řídit se jimi. Dále sebereflexe a přijetí odpovědnosti za vlastní činy, schopnost mít rád sebe i druhé, schopnost pěstovat odpovídající mezilidské vztahy a pohybovat se v sociálním prostoru bez výrazných konfliktů, zvládání konfliktů a situací v sociálním prostředí. Autor také zmiňuje schopnost přizpůsobit se.

Aktivní psychohygiena nám pomáhá zvládat stres. Tento aspekt je zásadní pro uplatnění člověka zejména na trhu práce. Bez určité míry odolnosti bychom pracovní zátěž nezvládli. V dnešní době se pracovní zátěž zvyšuje, a proto je důležité na zvyšování odolnosti aktivně pracovat, abychom zvýšili šance na své profesní uplatnění a nevyhořeli. Toto platí dvojnásob, pokud jedinec vykonává tzv. duševní práci, protože ta zvyšuje nároky na vnitřní vyrovnanost člověka (Paulík, 2017). V případě pedagogických pracovníků jsou kladeny extrémně vysoké nároky. Ďuričův výzkum z roku 1969 ukazuje, že nejvíce unavujícím faktorem v učitelské profesi je časové vytížení. To způsobuje dlouhodobé napětí, které může přerůst v syndrom vyhoření. Ze zmíněného výzkumu vyvstalo, že z celkového počtu 913 učitelů ZŠ pracovalo 24,5\% více než 60 hodin týdně. 
Pedagogická profese je zvláště náročná na psychohygienu, protože jsou na pedagogy kladeny vysoké nároky ze strany společnosti. Stresové situace nevycházejí pouze z přímé interakce se žáky, ale i z konfliktů s kolegy, vedením, partnery nebo školními inspektory (Nias, in Troman, 2000). P. Vyšínová (2013) uvádí, že očekávání vůči této profesi je obrovské - mají vychovávat, vzdělávat, realizovat vize společnosti, být oporou žákům a pomáhat jim ve všech situacích, mají být vzorem. Jsou zde vysoké nároky na odbornost, velké požadavky na praktické zkušenosti a také vysoké nároky na osobnostní předpoklady. Pedagogický pracovník je do své profese často (a je to žádoucí) osobně zainteresovaný, vytváří funkční vztahy se žáky, je obeznámen s jejich osobními i rodinnými problémy a je nápomocný v jejich řešení. Toto všechno ohrožuje duševní zdraví pedagoga. K duševní pohodě nepřispívá ani podfinancování profese a v poslední době vnímaný despektní pohled společnosti na profesi a jedince, kteří tuto profesi vykonávají. O nízké prestiži pedagogické profese se hovoří již delší dobu, avšak někteří autoři s tímto tvrzením nesouhlasí a potvrzují svá slova výzkumy, ve kterých se různé typy pedagogické profese umístily na různých místech v první desítce (Tuček \& Machonin, 1993; Průcha, 1995). Původcem stresu jsou také neustálé změny a reformy v resortu školství (Márová et al., 2015). Vyšínová (2013) zmiňuje, že v českém školství schází jakákoliv pomoc a systematická péče o duševní zdraví pedagogů, což nás opět vrací k naléhavé potřebě supervizí a osobnostním výcvikưm pedagogů zmíněným v předchozích kapitolách.

Mezi základní aspekty psychohygieny u pedagogické profese patří osvojit si systematičnost práce, práci se zdroji a novými technologiemi, schopnosti sebeprezentace, důležité je zvládnout time management a organizovat si svou práci (Bedrnová, 1996). Dovednost time managementu je velmi ceněná a snad i nezbytná - bez ní téměř nelze efektivně fungovat, proto se na rozvoj této dovednosti zaměřuje mnoho koučů a kurzů osobnostního rozvoje, kde se účastník naučí organizovat svůj čas, efektivně plánovat plnění svých povinností a udržovat pořádek nejen $\mathrm{v}$ povinnostech, ale také v pracovním prostoru. K dosažení efektivity učí koučové také efektivně využívat nové technologie, které mohou pomoci s plánováním (Stock, 2010; Paulík, 2017). Další zásadou psychohygieny je stanovení jasných, a především realistických cílů a priorit. Pro dosažení dobrých pracovních výsledků je vhodné stanovit dobrý pracovní režim a maximálně ho dodržovat, dbát na rozdělení času pro práci a odpočinek, a to vše přizpůsobit typu a náročnosti práce. Dbejme také na úpravu pracovního prostředí a celkové pracovní podmínky. V pěkném, čistém a uspořádaném pracovním prostoru se budeme cítit lépe a bude se to promítat do pracovní pohody a výkonu. Židle a pracovní stůl by měly mít vhodnou výšku, správné osvětlení, teplota v místnosti, kde pracujeme, by měla být okolo $21^{\circ} \mathrm{C}$, nehlučné prostředí, kde nezáleží pouze na hlasitosti, ale také na frekvenci akustických vjemů, vhodné nerušivé barvy a vzory v místnosti (Bartko, 1980; Vacínová 1995; Peterková, 2014; Paulík, 2017). Míček (1984) zdůrazňuje také psychologii barev a možnosti jejího využití v úpravě pracovního prostředí. 
Zmínili jsme aspekty psychohygieny, jako je seberozvoj, seberealizace a sebereflexe aj. Vlastní autoregulace a práce na osobnostním rozvoji je velmi důležitá a její potřeba se objevuje jak ve starších publikacích, tak i v těch nejnovějších. Míček (1986) píše, že sebepoznání je nejlepší cestou k upevnění duševního zdraví a adaptaci a že sebepoznáním začíná autoregulace a sebevýchova. S pojmy sebepoznání, sebevýchova, adaptace, autoregulace pracuje také Křivohlavý (2001), který chápe adaptaci jako adekvátní zvládání životních problémů. Sebepoznávání je velmi složitým procesem objevování vnitřních charakteristik, svých vlastností, rozpoznávání vlastních emocí a zkoumání svého komplexního Já. Sebepoznání a sebereflexe je mocným nástrojem pro dosažení vnitřní harmonie a větší odolnosti vůči stresu. Sebepoznání můžeme dosáhnout sebepozorováním, cílenou a pravidelnou sebereflexí, pravidelnou registrací vlastního chování. Sebepoznání mưžeme také dosáhnout pomocí druhých lidí, bud' za pomoci odborníka v rámci sebezkušenostního výcviku či psychoterapie, nebo osobnostně rozvojových kurzů, anebo rozhovory s lidmi, se kterými jsme v kontaktu, dotazováním, jak na ně působí naše chování, nebo pozorováním, jak na nás lidé reagují (Míček, 1986, Peterková, 2014; Paulík, 2017).

Vnitřní rovnováhy ale nedosáhneme pouze sebezpytováním. Člověk je bytost bio-psycho-sociální a tyto složky jsou vždy propojeny a vzájemně se ovlivňují, proto abychom se cítili dobře, nemůžeme pečovat jen o duševní zdraví, ale musíme dbát stejně zodpovědně i o zdraví tělesné. Člověk by měl být tělesně zdatný, aktivní a vnitřně odolný. K tomu je zapotřebí dobrá životospráva - pohyb, strava, spánek, relaxace. Tyto složky tvoří životní styl každého jedince (Bedrnová, 1996). Strava by měla být pravidelná, vyvážená, př́ijem by měl odpovídat výdeji. Měli bychom dbát na přísun prospěšných potravin, a naopak omezit škodlivé, jako jsou sladkosti, pochutiny, alkohol, kofein, polotovary a průmyslově zpracovávané potraviny. Jíst bychom měli v klidu a každý den bychom měli mít teplé jídlo. Jídlo ve spěchu není doménou pouze pedagogických profesí. $V$ dnešní uspěchané době plné fast foodů není jídlo za pochodu nic neobvyklého. Tyto chybné návyky bychom se měli snažit eliminovat. Míček (1986) i Bedrnová (1996) apelují na vytvoření pozitivních návyků a správné životosprávy, protože pomáhají upevnit duševní zdraví, zvyšují obranyschopnost organismu a pozitivně působí na pracovní výkon. Měli bychom snídat a neměli bychom jít spát ani hladoví, ale ani jíst těsně před spaním. Spánek je neméně důležitým aspektem duševní rovnováhy. Odborníci stanovili průměrnou dobu spánku na sedm až osm hodin, ale tato potřeba je individuální. Někomu stačí šest hodin, jiný potřebuje devět hodin spánku. Při dlouhodobém nedostatku spánku nám hrozí poruchy nervové činnosti. Stejně jako stravování, i spánek má své zásady a pravidla, aby byl kvalitní a člověk během něj načerpal síly a zregeneroval se. Základem je dobrá postel, matrace, tma, omezení sledování televize či práce na počítači alespoň hodinu před spaním. Důležitý je také pohodlný oděv, teplota v místnosti, která může být nižší než teplota v obývacím pokoji, Vobořilová (2015) 
uvádí vhodnou teplotu pro spánek $18^{\circ} \mathrm{C}$. Vhodné je také vytvoření rutiny. Odborníci na psychohygienu a spánek doporučují chodit spát a vstávat zhruba ve stejný čas.

K regeneraci nedochází jen během spánku, ale také během volného času. Je důležité trávit volný čas smysluplně a volit vhodné aktivity adekvátní k pracovní zátěži. Fyzické aktivity by měli zařadit zejména ti, kdo mají ve svém povolání málo pohybu, pracují „duševně“ nebo dochází ke statické zátěži. Vacínová (1995) uvádí, že ve volnočasových aktivitách se snažíme zatěžovat jiný orgán než ten, který namáháme v práci. Jedná se o aktivní odpočinek, protažení, které by mělo být součástí rutiny a osobního režimu každého jedince. Cvičení by mělo být adekvátní pracovnímu zatížení a zdravotnímu stavu. Cvičení formuje tělo, ale i mysl. Působí preventivně nejen proti různým nemocem a obezitě, ale má také pozitivní vliv na duševní rovnováhu jedince (Stock, 2010; Paulík, 2017)

S tímto také úzce souvisí relaxace. Pojem pochází z fyziologie a vyjadřuje uvolnění svalových vláken, přeneseně potom rozumíme relaxaci jako fyzické i psychické uvolnění. Způsobů relaxace je nepřeberné množství a každému vyhovuje něco jiného. Relaxace, zejména spojená se správným dýcháním, může navozovat i tělesné změny. Aktivuje se vegetativní nervový systém, snižuje krevní tlak, je ovlivněn metabolismus a dochází k biochemickým změnám. Relaxace umožňuje zvýšení serotoninu, který pozitivně ovlivňuje naši náladu. Relaxace může mít podobu dechových cvičení, meditace, jógy, Tai-či, dále Jacobsonovy progresivní svalové relaxace, Schultzova autogenního tréninku, imaginace, relaxovat můžeme za pomoci hudby, aromaterapie, ale i tance nebo malby (Míček, 1986; Drotárová \& Drotárová, 2003). Paulík (2017) řadí mezi relaxaci i modlitbu, která má podle autora spojitost s meditací a mindfulness, jelikož se při ní soustředíme na svůj vnitřní obsah.

Ve školním prostředí je mnohdy těžké výše popsané zásady dodržovat. Typické je jídlo ve spěchu nebo v přeplněných hlučných školních jídelnách, přepracovanost, vysoká vnitřní zainteresovanost, zatěžování hlasivek, dlouhé stání při přímé výuce, vedle toho dlouhé hodiny práce u stolu, na počítači při tvorbě př́iprav nebo při nutné byrokracii, stres a tlak ze strany žáků, rodičů, kolegů, vedení a celé společnosti. Pedagog, at' už učitel, vychovatel, nebo školní speciální pedagog by měli na zásady psychohygieny klást velký důraz, její principy by měli zařazovat do své denní rutiny, ty by se měly stát nedílnou součástí jejich života, protože jak zmiňuje Honzák (in Weiss, 2011), nejdříve se musí dobrý a zodpovědný profesionál postarat sám o sebe, pak teprve může jít příkladem druhým. Pedagog, který je spokojený, vyrovnaný a odpočatý, má naplněné své nejzákladnější potřeby, bude jistě dosahovat lepších výsledků než pedagog vyčerpaný a vyhořelý. 


\subsection{Copingové strategie a chování podporující kariéru}

Vliv blízkých sociálních vztahů je velmi významný, o to spíše v pomáhajících profesích, a tím i v profesi školního speciálního pedagoga. Pěstování pozitivních mezilidských vztahů naplňuje lidskou potřebu lásky, intimity, sdílení a důvěry. Z výzkumu Stevanovice a Ruperta (2004), ve kterém 286 náhodných licencovaných psychologů odpovídalo na otázky o chování podporujícím kariéru, o spokojenosti a stresu v práci (CSBq), vzešlo, že pozitivní mechanismy sociální podpory jsou velmi významné; trávení času s rodinou, partnery a blízkými přáteli je jednou z nejefektivnějších copingových strategií pro zvládání stresu a náročných situací. Taktéž je známo, že humor má pozitivní dopad na lidskou psychiku a může být důležitým nástrojem pro zvládání stresových situací. Humor může mít pozitivní efekt nejen na psychiku, ale také na fyzické zdraví jedince a celkový pocit pohody, tzv. wellbeing (Boyle \&Joss-Reid, 2004). Dle Coopera (2005) má také vliv na budování mezilidských vztahů. Ovlivňuje tedy i vztahy na pracovišti, a tím také pracovní klima (Decker \& Rotondo, 2001). Dle Gelkopfa a Kreitlera (1996) humor přináší novou perspektivu, nadhled a pomáhá vidět pozitivní stránky.

Copingové strategie jsou strategie, které nám pomáhají vyrovnat se se zátěžovou situací, která je subjektivně vnímána jako nad limit našich sil. Osvojení těchto strategií nám má pomoci situaci zvládnout a omezit negativní dopady zátěžové/stresové situace. Pro efektivní zvládnutí situace však musí člověk být aktivní a vědomě pracovat na zvládnutí situace. Právě pro vědomé a aktivní zvládání se ustálil termín coping (Paulík, 2017). Paulík (tamtéž) rozlišuje mezi adaptací a copingem. Adaptaci chápe jako zvládání zátěže jako takové, kdežto coping je uplatňován, pokud je zátěž vzhledem k odolnosti nadlimitní a člověk musí vyvinout zvýšené úsilí, aby se se zátěží vyrovnal. Lazarus určil ve své práci již v roce 1966 čtyři kategorie copingových strategií:

1. Útok na rušivé fenomény (noxa);

2. Aktivity $k$ posílení vlastní odolnosti a obranyschopnosti vưči těmto rušivým fenoménům;

3. Vyhýbání se rušivým fenoménům (noxám);

4. Apatie, bezmocnost, pocit beznaděje a deprese.

Později v dalších pracích $(1993,1994)$ určil dva základní typy copingu dle jejich působení, a to (1) coping zaměřený na problém nebo (2) coping zaměřený na emoce. Konkrétní typ strategie volíme na základě vyhodnocení aktuální situace. V prvním případě (problem-focused coping) se snažíme odpovídajícím úsilím změnit situaci k lepšímu skrze úpravu okolností a vlastního chování, zaměřujeme se na původce stresu; jde o přímou akci, využití a získávání informací a jejich uplatňování při modifikaci vlastního chování nebo při změnách v prostředí. Patří sem také aktivní vyhledávání pomoci u druhých. V druhém případě (emotion-focused coping) se snažíme použít takové strategie, které nám pomohou dostat emoce pod kontrolu, aby nenarušovaly 
integritu jedince a jeho vztahy s okolím. Obvykle aktivujeme druhý typ strategií, pakliže vyhodnotíme, že se se situací nedá nic dělat. Snažíme se ovládnout emoce doprovázející stresovou situaci a eliminovat tak škody, které by mohly tyto emoce napáchat. „Účinné zvládnutí vlastních emocí umožňuje člověku celkové zklidnění a dosažení odstupu od problému“ (Paulík, 2017, s. 119). Jiní autoři také hovoří o tzv. dysfunkčních copingových strategiích. Například Carver, Scheier a Weintraub (1989) charakterizují dysfunkční strategie jako projevování negativních emocí; oddálení (mentální a behaviorální) jako snaha odpoutat se od problému tím, že se člověk zaměří na jiné aktivity, projevy pasivity a rezignace na cíle; snaha uniknout ze situace a vyhýbání se jejímu řešení (např́iklad za pomoci návykových látek). Do strategií copingu zaměřeného na emoce mohou často spadat nefunkční strategie jako vytěsnění a popření. Rozdělení strategií do dvou skupin je však pouze konstruktem a snahou o teoretické vymezení. V praxi však ve většině případů využíváme kombinaci obou strategií, jak strategie zaměřené na emoce, tak strategie zaměřené na problém (Folkman \& Lazarus, 1980).

Někteří autoři (například Strnadová, 2001; Pecák, 2013; Paulík, 2017) hovoří o copingu s ohledem na časovou perspektivu. Rozlišují dva typy - první je coping reaktivní nebo anticipační. Zde se jedná o bezprostřední hrozbu, zvládání stresu, který již nastal. Druhým typem je proaktivní nebo také preventivní coping, který je zaměřen na potenciální zátěžové situace, hrozby, které jsou pravděpodobné ve vzdálenější budoucnosti. Již v kapitole věnované psychohygieně jsme hovořili o potřebě sebekontroly a autoregulace. Obě dovednosti hrají důležitou roli také v copingu. Jak píše Paulík (2017), lze coping chápat jako obecnější pojem, který také zahrnuje sebekontrolu a autoregulaci. Na sebekontrolu a autoregulaci lze také pohlížet jako na širší pojem, který dle Lovaše et al. (2011) zahrnuje nejen coping, ale také procesy, které jsou uplatňovány mimo stresové situace.

Ve smyslu zvládání stresových situací popisuje Paulík (2017) ještě dva důležité pojmy - copingové strategie a styly. Copingové styly chápeme jako soubor naučených konzistentních reakcí a způsobů chování. Jsou osobnostně zakotvené a uplatňujeme je, když se ocitneme ve stresové situaci. Jedná se o obecné vzorce chování a proživání, které jsou charakteristické pro každého konkrétního jedince, zvláště tendence posuzovat situaci určitým způsobem. Styl zvládání je zakotven v naší osobnosti, je víceméně neměnný a oproti strategiím je copingový (zvládací) styl spíše obecné a stabilnější povahy. Křivohlavý (1994) definuje strategie jako plán nebo postup zaměřený na konkrétní cíl. Oproti konzistentnímu zvládacímu stylu jsou copingové strategie tvárné a proměnlivé, zejména v závislosti na dané situaci. Strategie jsou oproti stylu více podmíněny učením konkrétních úkonů (Paulík, 2017). Křivohlavý pak hovoří ještě o taktikách zvládání, které jsou na žebřičču obecnosti ještě níže a mají význam spíše konkrétních kroků ve smyslu „ted' a tady“. Taktiky jsou drobné a konkrétní postupy vedoucí k řešení a vyřešení konkrétní zátěžové situace. Pokud bychom chtěli zdůraznit uplatňování určitých dovedností, nabízí Paulík (tamtéž) také termín techniky zvládání (z řeckého techné - dovednost). 
Lazarus (1966) se copingovými strategiemi zabýval velmi intenzivně a v rámci dotazníku Ways of Coping Questionnaire (WOCQ) vymezil osm konkrétnějších skupin zvládacích strategií. Jedná se o strategie konfrontující, strategie sebekontroly, strategie oddálení, únik/vyhýbání se, strategie vyhledání sociální opory, strategie přijetí odpovědnosti, strategie zaměřené na řešení problému a strategie pozitivního přehodnocení.

Výše popsané copingové strategie jsou obecné mechanismy platné ve všech stresových životních situacích. V roce 1982 vytvořil Brodie užší model zabývající se chováním podporujícím kariéru a vytvořil dotazník Career Sustaining Behaviors Questionnairese (CSBq) a zaměřuje se v něm na přizpůsobení se v rámci osobního a pracovního života. Dotazník procházel vývojem a vzniklo mnoho navazujících studií. Stevanovic a Rupert (2004) uvádějí ve výše zmíněném výzkumu, že respondenti, kteří byli dle dotazníku hodnoceni nejlépe, trávili hodně času s rodinou, soustředili se na udržení rovnováhy mezi osobním životem a prací a zachovávali si smysl pro humor. V dotazníku vyvstaly také rozdíly mezi muži a ženami. Ženy obecně uplatňovaly více strategií chování podporujících kariéru, také více vykazovaly chování, které mělo vztahový a vzdělávací charakter, jako třeba osobní terapie, trávení času s přáteli, profesní sdílení, vyhledávání pomoci a rady - konzultace případů s kolegy, další vzdělávání, smysluplné trávení volného času a volba klidnějších volnočasových aktivit. Další uvedené strategie jsou zachování profesní identity a sebeuvědomění, reflexe pozitivních zkušeností, zachovávání objektivity vůči klientům, ale také pravidelná dovolená, směřování ke spirituálním hodnotám a zachování kontroly.

Sebeuvědomění je neméně zásadní kategorií. Cílené sebeuvědomování nám pomáhá v osobnostním růstu a přijetí odpovědnosti za naše chování, jednání a rozhodnutí. Na osobnostním růstu, sebepoznání a sebepřijetí můžeme pracovat sami nebo za pomoci odborníků z řad koučů, psychologů a terapeutů. Kucharská et al. (2013) doporučují, aby odborníci, jako jsou školní speciální pedagog, ale i řadový učitel, stejně jako školní psycholog (a mnohé další profese) absolvovali sebezkušenostní či psychoterapeutický výcvik, který značně rozšiří jejich profesní rámec. Sebeuvědomění nám pomáhá přijmout sebe sama a nalézt naše vlastní limity, což umožňuje profesionálům poskytovat kvalitnější péči o jejich klienty, také proto, že sebeuvědomění pomáhá být citlivější i k vlastním potřebám, a tak spíše poznáme, kdy se věnujeme práci přespř́liš a potřebujeme načerpat nové síly (Kucharská et al., 2013; Waltman, Frankel, \& Williston, 2016; Ingstrup et al., 2017). S tímto také souvisí další položka a copingová strategie uvedená v dotazníku chování podporujícím kariéru, a to rovnováha mezi osobním a profesním životem. Ideální vyvážení je však individuální a závisí na hodnotách daného jedince. Orientačním bodem by mohla být spokojenost konkrétního člověka s vyvážením těchto dvou položek (Reiter, 2007). S vyvážením práce a osobního života dále souvisí i další strategie odpočinkové aktivity a fyzická aktivita. Sem patří smysluplné trávení volného času, pravidelné zařazování odpočinku, dovolené, vhodná volba odpočinkových aktivit odpovídajících typu práce a výkonu. Tomuto tématu jsme se věnovali také v kapitole Psychohygiena 
a pedagogická profese, kdy jsme zmínili, že k regeneraci nedochází jen během spánku, ale také mj. během volného času. Aktivity ve volném čase by měly být protipólem pracovní zátěže. Pokud máme sedavé povolání, měli bychom do svého volného času zařadit pohyb, pokud pracujeme fyzicky, můžeme trávit volný čas klidnějšími odpočinkovými aktivitami (Vacínová, 1995). Pohyb a fyzická aktivita působí na tělo i mysl, napomáhá odreagování, pomáhá nastolit duševní rovnováhu a díky fyziologickým procesům má vliv na aktuální zlepšení nálady (Stock, 2010; Paulík, 2017). O potřebě profesního sdílení, pravidelné supervizi a intervizi, konzultování pracovních případů už bylo také psáno výše. Ve vztahu ke školnímu speciálnímu pedagogovi o tomto tématu píší například Kucharská et al. (2013).

Dotazník Career Sustaining Behaviors Questionnairese (CSBq) se sice původně zaměřuje na psychology a terapeuty, nicméně zjištění jsou bezpochyby aplikovatelná i v obecné rovině a mohou z nich čerpat i jiné profese pracující s lidmi, mj. učitelé či školní speciální pedagogové a lidé pracující v pomáhajících profesích. 


\section{Etické aspekty profese}

V pomáhajících profesích, kam školní speciální pedagog bezesporu patří, lze vnímat za velmi důležité etické zásady profese. Pracovníci se ve své praxi setkávají s náročnými situacemi, ve kterých může být hranice etiky ne zcela jasná. Tyto problematické situace pomáhá eliminovat a řešit etický kodex, který však pro školní speciální pedagogy zatím nebyl vytvořen.

Jankovský (2003) definuje etiku jako praktickou filozofii, která reprezentuje vztah člověka ke světu. Kolébkou etiky je starověká řecká filozofie a velikáni jako např́íklad Aristoteles nebo Hippokrates, který vytvořil snad první profesní kodex, dnes známý jako Hippokratova přísaha, kterou skládají lékaři a slibují tak, že budou pacientům pomáhat, léčit je, a to vždy s ohledem na všechny etické principy. Přísahající slibuje úctu ke svému učiteli, ochotu dále umění zdarma předávat a také to, že všechny úkony budou vždy v zájmu pacienta. Tento slib prošel vývojem, $v$ jednotlivých zemích se liší a některé sliby dnes již ani s ohledem na právní normu platit nemohou (např́klad interrupce či v některých zemích eutanazie). Změnil se i prrístup pacientů ke zdraví, ale i ke zdravotnictví a nutně se tedy musel změnit i př́stup zdravotníků k pacientům. Nelze se tedy o etickou normu opírat vždy a za každé situace, i když měla Hippokratova př́saha zásadní vliv na tvorbu etických norem a mnohých profesních kodexů, nejedná se v žádném případě o normu právní či právním normám rovnou (Vondráček, 2001).

Zpět k etice. Její počátky jsou již v době mýtů, avšak o etice jako o vědě lze hovořit až tehdy, kdy má svůj předmět. Tím se stala morálka - hodnocení lidského jednání z pohledu dobra a zla s odkazem na svědomí jedince. Etika a morálka nejsou v žádném př́ípadě synonyma. Rozšǐríme-li Jankovského (2003, s. 22) definici jeho vlastními slovy, pak hovoříme o etice jako o filozofické vědě „o správném způsobu života, vycházející z racionálních přístupů a snažící se nalézt, popřípadě i zdůvodnit, společenské a obecné základy, na nichž morálka (předmět etiky) stojí". Jankovský (tamtéž) dále shrnuje své definice do tvrzení, že etika je teorií morálky. Morálku, vycházeje z latinského plurálního výrazu „mores“ (zvyk, obyčej, mrav nebo v původním slova smyslu také vůle, která je člověku dána autoritou, tedy zákony a předpisy), definuje jako soubor všeobecně uznávaných mravních norem, které vyplývají z určitého chápání hodnot, jejich povahy a hierarchie. Mravně jednáme tehdy, jednáme-li v souladu s naším svědomím. To platí zejména v momentě, kdy 
jednáme i proti svému užitku a prospěchu. Chybí zde racionální kalkulace a jedná se spíše o cit a sebeúctu, „o niterný imperativ naléhavě nám sdělující, že musíme ,něco udělat, nehledě na aktuální důsledky tohoto našeho činu“ (Jankovský, 2003, s. 28). Mravnost tedy není jen otázkou rozumu, ale také emocionální stránky. Nelze ji naučit a je záležitostí kultivace citové sféry. Autor pohlíži na etiku z různých pohledů a dělí ji na etiku náboženskou, autonomní, heteronomní, individuální, sociální, ekologickou etiku, bioetiku aj. Nás ovšem zajímá především profesní etika. Ta aplikuje svá obecná ustanovení (etické kodexy) na jednotlivé profese a jejich činnosti.

Zejména v profesích, kde pracujeme s lidmi, jsou důležité etické kodexy a jejich striktní dodržování, i když jejich výklad může být místy nejasný nebo je linie etiky velmi tenká a je složité tuto hranici rozpoznat a ctít. Baštecká a Goldman (Ptáček et al., 2011) píší, že etika je důležitá, často zmiňovaná v poslední době ve smyslu potřeby zejména v pomáhajících profesích, ale mnohdy nemá konkrétní obsah a všimneme si jí, až když chybí. Haškovcová (in Ptáček, 2011) se zabývá etickými kodexy a zamýšlí se nad jejich funkčností. Na poli medicíny kritizuje odstoupení od tradičních ideálů a principů, které se však netýkají jen medicíny, ale všech pomáhajících profesí a profesí, kde pracujeme a jednáme s lidmi. Základním principem těchto oborů by měla být starost o svěřené a druhým principem jasné vymezení rolí tak, aby byla zachována důvěra k odborníkovi a eliminovala diktát z obou stran. Pravidla mohou být funkční pouze tehdy, když jsou oběma stranami akceptovatelná. Pro vznik funkčních profesionálních vztahů nejsou nic platné ušlechtilé apely ani etické kodexy. Haškovcová (2006) skepticky označuje kodexy jako „snůšky svatých pravd“, které představují moderní formalitu a past s iluzí řešených problémů, nikoliv záchranu v rychle se měnící realitě. Potřeba etických kodexů vyvstává z potřeby eliminovat problematické a nejasné situace, což je ale požadavek nereálný, protože etické kodexy jsou př́liš obecné, nicméně z obecných formulací cílů a zásad můžeme vyvodit konkrétní návody přiléhající ke specifikům dané profese (Kucharská et al., 2013).

Etickými aspekty nebo etikou obecně je myšleno obecné dodržování morálních zásad, které by měli dodržovat všichni ti, kteří pracují v pomáhajících profesích. Kucharská (tamtéž) zdůrazňuje chování ve prospěch klienta více než ve prospěch instituce. Školní speciální pedagog je při své činnosti vystaven mnoha náročným situacím, kdy zvažuje etické aspekty jednání. ŠsP „bývá vystaven tlakům na sdělování, predávání informací o klientech a tlaku svých nadřízených či jiných institucí. Musí si být vědom dopadu své činnosti na klienty, a tím také připustit zodpovědnost, kterou to přináši“ (Kucharská et al., 2013, s. 189).

Jak již bylo zmíněno, školní speciální pedagogové zatím nemají v ČR svůj ustanovený etický kodex. Tato profesní skupina je relativně nová, ještě ne plně etablovaná. Jak píše Kucharská et al. (2013), ŠSP však mohou čerpat inspiraci z již existujících kodexů př́buzných profesí, např́klad Etických norem práce školního psychologa (Oakland, Goldmanová \& Bishoff, 1994), schválené 
V roce 1994 Asociací školní psychologie v ČR, Etického kodexu pracovníků SPC, který byl schválen Asociací pracovníků SPC v roce 2006, Etického kodexu pracovníků SVP (Čedík, 2002) nebo Etického kodexu sociálních pracovníků ČR (schválen v roce 2006). Obecná ustanovení těchto dokumentů apelují na dodržování lidských práv a jejich základ je v mezinárodních dokumentech jako Ústava ČR, Úmluva o právech dítěte, Listina základních práv a svobod, Charta lidských práv Spojených národů, Všeobecná deklarace lidských práv. Překvapivé je, že v ČR dosud nebyl přijat etický kodex učitele, i když o této potřebě je vedena neustálá diskuse. Např́klad Čech (2011b) apeluje na jeho přijetí mj. s výskytem mobbingu v prostředí základních škol. O krok dále jsou v tomto ohledu na Slovensku, kde byl etický kodex učitele přijat Slovenskou komorou učitelů v roce 2017.

Etické kodexy obsahují typ poskytovaných služeb a odrážejí respekt ke klientům. Popisují také profesionální normy a omezení z profese vyplývající, jako například poskytnutí pouze takových služeb, ke kterým je pracovník kompetentní. Rozsáhlou oblastí ošetřenou ve většině etických kodexů je profesionální odpovědnost, tzn. znalost legislativního rámce, znalost principů a cílů instituce nebo systému, ale také snaha o osobnostní i odborný růst. Profesionál by si měl uvědomovat potřebu dalšího vzdělávání, měl by si udržovat přehled o nejnovějších poznatcích daného oboru, také by si měl být schopen uvědomit potřebu spolupráce a konzultace s dalšími odborníky nebo supervizorem.

Profesionál by se měl vyvarovat předsudků, diskriminace a střetu zájmů. Kucharská et al. (2013) uvádějí, že v případě střetu zájmů mezi dětmi a dospělými preferuje odborník zájmy dětí, žáků a studentů, ale vše tak činí s informovaným souhlasem rodičů, který lze vynechat pouze v ojedinělých situacích, které jsou krizové a pro dítě nebezpečné, případě rizikové pro ostatní.

Profesionál se také vyvaruje tajných dohod a vyvolávání konfliktů, v jejichž pozadí je osobní důvod, případně politický či ekonomický. Vždy jedná v zájmu klienta, pro jeho blaho, chrání jeho zájmy, důstojnost a autonomii, vede ho k samostatnosti, odpovědnosti a aktivitě. Nepřebírá za klienta více odpovědnosti, než je nezbytně nutné. Vždy se snaží přiblížit cíle a podstatu intervence tak, aby to bylo pro klienta srozumitelné. Projednává s klientem plány a postupy i možné alternativy, vždy s respektujícím přístupem v rovině partnerství a rovnocennosti. Tak, aby se klient mohl na řešení svého problému podílet.

Důvěrné informace může pracovník poskytovat pouze se souhlasem klienta nebo jeho zákonných zástupců, jinak udržuje informace v tajnosti. Důvěrné informace sdílí pouze s odborníky majícími jasný profesní vztah ke konkrétnímu př́padu. ŠSP má závazky ke škole, proto je velmi těžké držet se všech zmíněných principů. Pokud dojde ke konfliktu zájmů mezi zájmem klienta a závazky ŠSP ke škole, je povinností odborníka informovat klienty o tom, co ze závazku plyne, a umožnit jim volbu, zda zůstanou v péči ŠSP, či nikoliv (Slavíková, 2006). Kucharská et al. (2013) doplňují téma sdílení informací komentářem, že ač je udržování důvěrných informací zcela legitimním 
požadavkem, není př́liš výhodné, zejména pokud s učitelským sborem teprve budujeme svůj vztah, př́liš tento nárok akcentovat. „Př́lišný důraz na zachování důvěrných informací přednesený v obecné rovině bez vztahu ke konkrétní kauze může u kolegů v rámci ŠPP či kolegů učitelů vyvolat pocity negativního vymezování vi̊či nim, které pak mohou být vnímány v rozporu s dalším etickým pravidlem - snahou rozvíjet s kolegy harmonické, kooperativní vztahy“ (Kucharská et al., 2013, s. 193).

Profesionální praxe z hlediska etiky se požadavku na pěstování profesionálních vztahů dotýká velmi vysokou měrou. Nejedná se pouze o vztah s klienty či kolegy, ale všemi osobami, se kterými při výkonu své profese přijde odborník do kontaktu. Na půdě školy může docházet ke konfliktu rolí, kdy je náš kolega v určitou chvíli naším klientem. Slavíková (2006) upozorňuje na nezneužívání svého vlivu ve vztahu k rodičům. ŠSP může mít na rodiče velký vliv, potřebuje jejich důvěru a někdy se může jednat až téměř o závislost. Každý profesionál by se měl vyvarovat zneužití této důvěry či závislosti k uspokojování vlastní potřeby řídit někoho a rozhodovat za něj dle svého vlastního přesvědčení. Kucharská et al. (2013) vnímá tento aspekt etických zásad ve školství i v pomáhajících profesích za až přespříliš často překračovaný. Soudí, že pomáhající pracovníci často vyhodnocují situaci za klienty a vyvíjí na ně nátlak, aby jejich rozhodnutí a doporučení přijali. Jak ve vztahu ke klientům, tak ve vztahu ke kolegům musí ŠSP respektovat názory druhých. Pakliže soudí, že se kolega chová neeticky, upozorní ho přímo. Připomínky vyjadřuje vhodně, eticky, konstruktivně, na vhodném místě a ve vhodné situaci. Pracovník se snaží o perspektivní kooperující vztahy s kolegy, klienty a př́slušnými organizacemi či úřady tak, aby všechny strany sledovaly linii efektivní a provázané logické spolupráce. Kompetence by se měly vymezovat, ale i sdílet a propojovat.

Vycházíme-li z předpokladu, že školní speciální pedagog realizuje také dílčí výzkumná šetření a diagnostiku (sám nebo v týmu), je třeba zmínit rovněž aspekty etiky výzkumu. Zde je nanejvýš nutné dodržovat principy etiky, kdy jako první je nutné zvážení vůbec etické přijatelnosti daného výzkumu. Pracovník vždy musí upozornit všechny zainteresované osoby o probíhajícím výzkumu, jeho cílech a podstatě a musí respektovat právo odmítnout účast nebo svou účast v průběhu výzkumu ukončit. Musí také zajistit, aby nedošlo k žádné újmě účastníků, ručí za exaktnost výsledků a na závěr podává korektní zprávu o zjištěních a výsledcích výzkumu. Dále je povinen řádně ve svém výzkumu citovat autory přejatých myšlenek a přiznat zásluhy ostatním spolupracovníkům podílejícím se na publikaci či výzkumu (Kucharská et al., 2013). Hlouběji se otázkou etiky v pedagogickém výzkumu zabývají autoři Průcha a Švařiček (2009); na stránkách MŠMT je mj. dostupný dokument Etický rámec výzkumu (2015).

Vzhledem ke zvyšujícímu se počtu žáků z odlišného sociokulturního prostředí na půdě českých škol je nezbytné se pozastavit u problematiky náboženství a etiky. Náboženské směry jsou různé, jejich variabilita roste 
a v poslední době v důsledku imigračních vln vzrůstá i citlivost těchto témat. Jankovský (2003) hovoří o náboženské etice jako o vděčnosti Bohu/bohům, od které se odvíjí i jednání člověka. Autor připomíná, že je vhodné brát v potaz etické principy náboženství, jelikož formovaly naši kulturu a tradice, nicméně etické chování není monopolem jen některých náboženských směrů, protože prochází celou společností a dějinami lidstva. V současnosti k nám vedle křestanské a židovské tradice přichází stále více také islám, východní filozofické směry a myšlení, nová hnutí, která usilují o kvalitu života a hodnot. Kucharská et al. (2013) zmiňují i negativní formy s iracionálními a pokleslými formami komercionalizace a fundamentalismu, hovoří také o manipulativních sektách s vystupňovaným autoritářstvím a nevhodným způsobem komunitního života, což směřuje k úvahám o preventivní práci s dětmi ve vztahu k těmto rizikovým extrémním vlivům.

Být pracovníkem v pomáhající profesi nemůže být každý. Jako k jakékoliv jiné profesi i k této musíme mít určité předpoklady, a to jak v rovině osobnostních dispozic, tak vzdělání. V pomáhajících profesích výkon povolání často žádá od pracovníka jisté oběti. Žádnou z pomáhajících profesí nelze vykonávat bez respektování etických zásad a bez ochoty pomáhat druhým. V historii byly některé profese považovány za posvátné a byly vázány slibem, byly tak zapotřebí nejen dostatečné znalosti a dovednosti, ale také ryzí charakter, mravní čistota a odpovědnost vůči vyššímu mravnímu řádu (Halík, 1993).

Profese školního speciálního pedagoga má velmi úzký vztah k lidem, stejně jako mnoho dalších profesí spadajících do kategorie pomáhající. Etické otázky provází tyto profese každodenní praxí, někdy jsou zcela jasné a evidentní, jindy se pohybují na velmi tenké hraně. Pro takové př́pady vznikají zmiňované profesní kodexy, které formulují všeobecně platné normy a morální zásady, kterými by se měl odborník řídit a hledat v nich oporu, pokud se nalézá v nejasné situaci. Závěrem zmiňme slova J. Jankovského (2003, s. 189): „Lidské být je být odpovědným a odpovědnost je (vedle porozumění, obětavosti, empatie, prosociálního jednání atp.) také jedním ze základních předpokladů pro úspěšný výkon pomáhajících povolání." 


\section{Profesní obraz školního speciálního pedagoga ve výzkumné reflexi}

Výzkum, realizovaný k tématu publikace, byl orientován kvalitativně a pro zjištění náplnĕ práce a nároků, které na jedince klade profese školního speciálního pedagoga, sloužil sběr dat prostřednictvím polostrukturovaných rozhovorů. Výzkum sleduje specifika profese školního speciálního pedagoga, mj. náplň práce, denní agendu či profesní sebeobraz. Zabýval se také pracovní zátěží a způsoby, jak se se zátěží a stresem školní speciální pedagogové vyrovnávají. Pro analýzu dat byla zvolena metoda zakotvené teorie a očekávaným výstupem je náhled do nové profese a jejích specifik.

\subsection{Východiska a metodologie výzkumu}

V předcházejících kapitolách jsme se zabývali nejrůznějšími teoretickými aspekty profese školního speciálního pedagoga v širším i užším kontextu legislativou, společenskými přístupy ke vzdělávání, příbuznými a spolupracujícími obory, aspekty psychohygieny a copingovými strategiemi zvládání stresu a pracovní zátěže. Definováním těchto kategorií jsme vytvořili konceptuální rámec pro náš výzkum.

Cílem výzkumu je zjistit a popsat specifika profese školního speciálního pedagoga, a to ve výzkumné reflexi ucelující poznatky a zkušenosti pracovníků, kteří působí na pozici ŠSP na základní škole. Sledovali jsme, jaká je nápln̆ jejich práce a jak vnímají ŠSP svou pozici a profesní roli vůči škole, kolegům učitelům a dalším odborníkům, ale také vůči společnosti. Pokusili jsme se nahlédnout rovněž do procesů zvládání stresu a poukázat na potřebu psychohygieny a vědomé práce na osobnostním rozvoji a copingových strategií u pedagogických pracovníků. K nalezení odpovědí na výzkumné otázky, jak již bylo zmíněno, jsme zvolili cestu kvalitativního výzkumu a zakotvené teorie, která přinese nový ucelující náhled na profesi školního speciálního pedagoga v prostředí základní školy. Výzkum byl realizován v souladu s kroky zakotvené teorie autorů Strauss a Corbinová (2008 - viz obrázek 1) s oporou postupů Řiháčka a Hytycha (2013). 


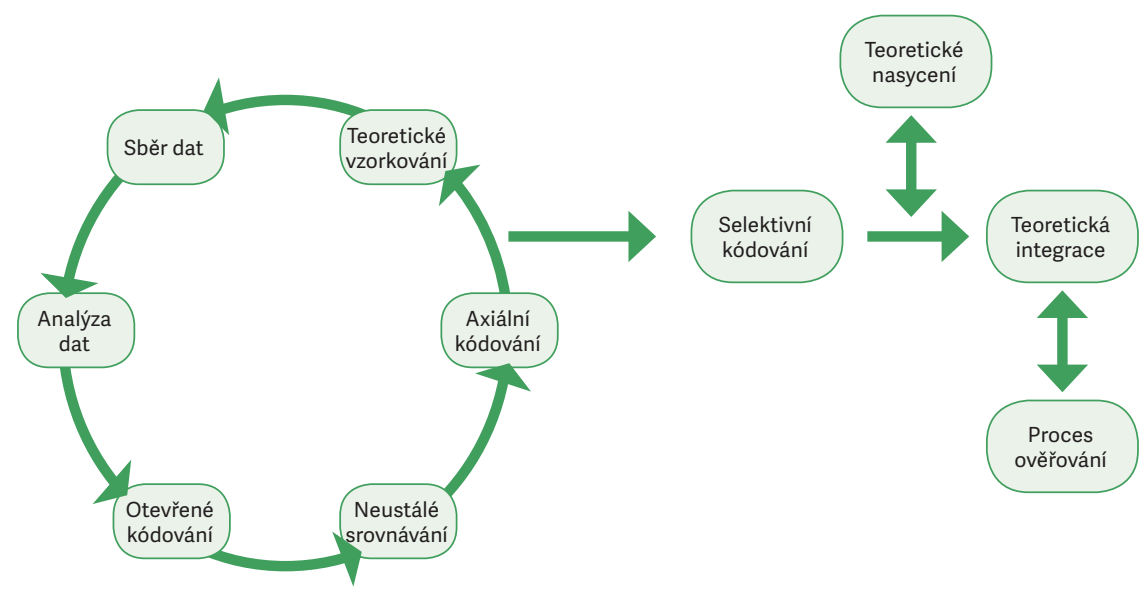

Obr. 1 Kroky zakotvené teorie (Strauss \& Corbinová, 2008)

V návaznosti na cíl výzkumu jsme jako hlavní výzkumnou otázkou stanovili: Jaká jsou specifika profese školního speciálního pedagoga na základní škole?

Specifickým zájmem našeho šetření bylo odpovědět na tyto otázky:

- Jaká je pracovní náplň školního speciálního pedagoga na základní škole?

- Jaká je pracovní zátěž školních speciálních pedagogư?

- Jak se školní speciální pedagog vyrovnává s pracovní zátěží a jaké jsou jeho strategie zvládání?

- Jak vnímá školní speciální pedagog svou profesní roli?

- Jak vnímá školní speciální pedagog své postavení mezi pedagogy?

- Jaké existují limity v práci školního speciálního pedagoga?

- Jak se školní speciální pedagog podílí na životě školy, na práci s učiteli a rodinami žáků?

Výzkumný soubor je tvořen sedmi informantkami z České republiky pracujícími na pozici školní speciální pedagožky na základních školách a osmiletých gymnáziích. Soubor nebyl limitován věkem ani pohlavím, nicméně v této profesi dominují ženy a žádný muž se výzkumu nezúčastnil. Kritériem pro zařazení do výzkumného souboru byla délka praxe, přičemž horní hranice nebyla určena, ale požadovaná délka praxe v pozici školního speciálního pedagoga byla minimálně jeden rok. 


\subsection{Profese školního speciálního pedagoga - výzkumná analýza}

Řiháček a Hytych (2013) rozdělují pro didaktické účely analýzu do tří fázítvorba konceptů, hledání teoretických vztahů mezi koncepty a volba ústředního konceptu a formulace teorie. Autoři upozorn̆ují, že terminologie se u různých autorů liší, a proto se zmínění autoři drží svého vlastního, trochu obecnějš́ího, pojmenování. Obdobně hovoří i Strauss a Corbinová (1999, 2008), kteří upozorn̆ují na různorodost v pojetí zakotvené teorie. Schéma postupu zakotvené teorie vyobrazené v kapitole 5.1 vychází právě z pojetí Strausse a Corbinové, jejichž modelu se budeme pro transparentnost výzkumných postupů $\mathrm{v}$ analýze držet, nicméně pro lepší pochopení a správné aplikování metody zakotvené teorie bude někdy reflektováno také pojetí Řiháčka a Hytycha (2013).

\subsubsection{Od nutné agendy po odbornou spolupráci (otevřené kódování)}

Zajímavý je sám postup otevřeného kódování získaných dat, který odhaluje cestu k vzešlým kategoriím. Dle Řiháčka a Hytycha (2013) odráží otevřenost výzkumníka k objevování nových významových jednotek. Ono nalézání významových jednotek je právě prvním krokem analýzy (Miovský, 2006). To jsou úseky, které nesou informace vztahující se k výzkumné otázce. Tyto významové jednotky se vyznačují v textu a stručně pojmenují. Kódy by měly vyjadřovat podstatu významové jednotky (Řiháček \& Hytych, 2013).

Při analýze rozsáhlých textů vzniká velké množství konceptů a kódů. Ty se na základě podobnosti spojují do obecnějších konceptů, které se dále propracovávají a popisují se dle vlastností a dimenzí, přičemž vlastnosti definují to, co mají prvky dané kategorie společné. Dimenze naopak charakterizují jejich vnitřní variabilitu (Řiháček \& Hytych, 2013). Autoři (tamtéž) dodávají, že čím více jsme schopni o konceptu rríci, tím je pro analýzu důležitější a tím klíčovější místo bude zaujímat.

Otevřené kódování může být nekonečný proces a výzkumník by byl zaplaven množstvím konceptů, což ovšem není žádoucí zejména pro časové omezení, ale také proto, že k tvorbě teorie není potřeba takového množství konceptů. Stačí najít ty nejrelevantnější a zabývat se dále těmi, které nejvíce reflektují na výzkumnou otázku. U nich pak výzkumník rozvíjí vlastnosti a dimenze a z otevřeného kódování přechází k dalším krokưm analýzy.

Obrázek 2, vycházející z prvotní analýzy dat, poukazuje na ohniska analýzy a jejich vztahy, jsou z něj již patrny rýsující se klíčové kategorie, které vyvstaly na základě otevřeného kódování. 


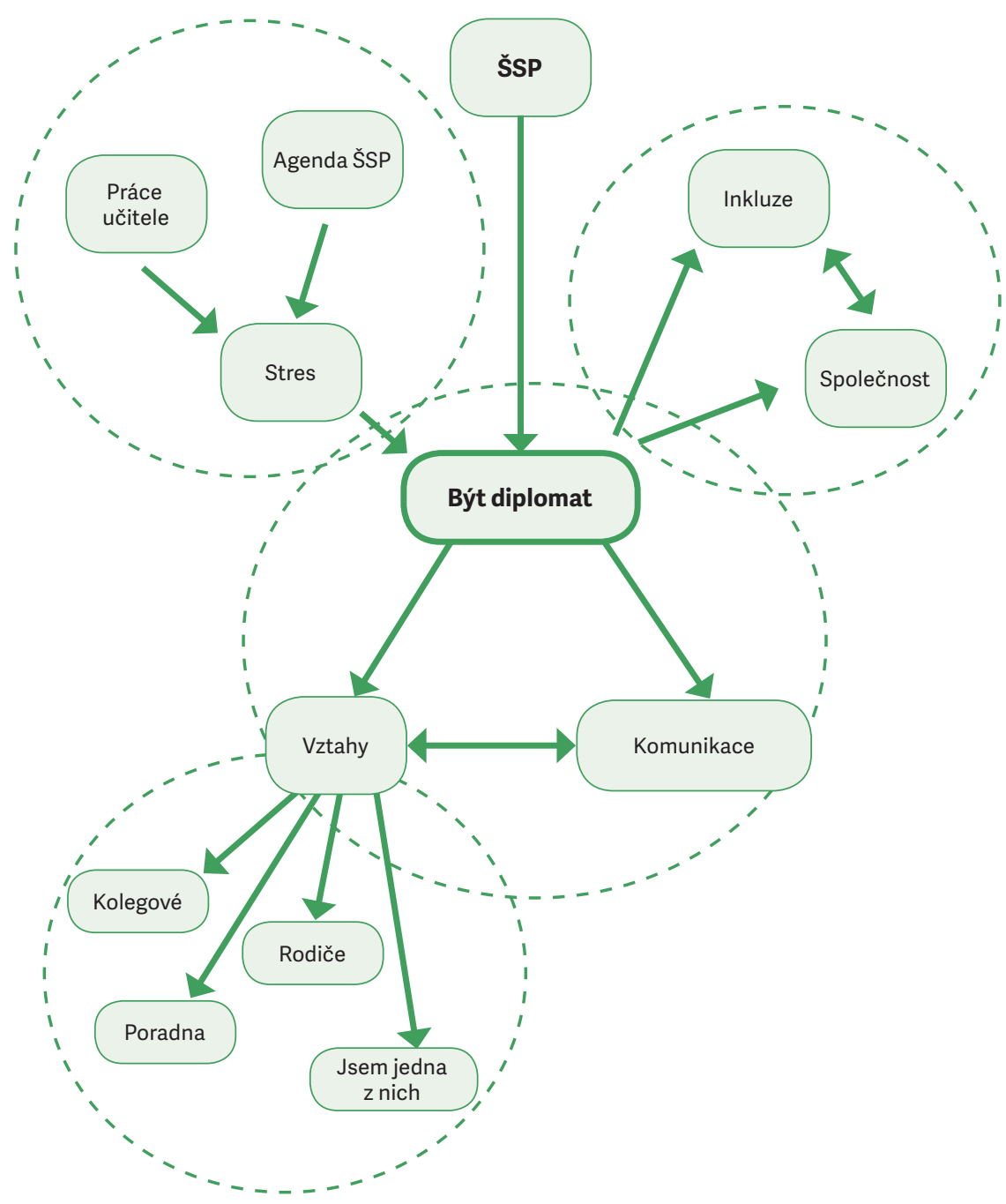

Obr. 2 Mapa konceptů na základě otevřeného kódování

Některé kategorie se již od počátku zdály pro analýzu nosné a klíčové a bylo zřejmé, že budou hrát významnou roli ve vztahu k cíli výzkumu a výzkumným otázkám. Některá témata byla naopak spíše ojedinělá u konkrétních respondentů, což mohlo být dáno např́klad věkem či zkušenostmi respondentky nebo také filozofií konkrétní školy.

Nejvýznamnější kategorie, které na základě analýzy prostřednictvím otevřeného kódování vyvstaly a se kterými jsme dále pracovali, jsme nazvali:

\section{Agenda a denní rutina školního speciálního pedagoga;}

2. Identita školního speciálního pedagoga;

3. Spolupráce $\mathrm{v}$ rámci profese školního speciálního pedagoga;

4. Stres v profesi školního speciálního pedagoga; 


\section{Kontext společnosti a jeho vliv na profesi školního speciálního pedago- ga; \\ 6. Být diplomat; \\ 7. Vliv školy na výkon profese školního speciálního pedagoga.}

Pro zajímavost uvádíme ještě několik kategorií, které z kódování vyvstaly, ale nejevily se jako nosné a významné pro naši analýzu. Nebyly tak do výzkumu samostatně zahrnuty, nicméně považujeme je za zajímavé a dalo by se na ně zaměřit v rámci jiného výzkumu:

1. Financování a nejistoty;

2. Asistent pedagoga a práce učitele;

3. Jsem jedna $z$ nich;

4. Sdílení;

5. Moje pozice.

Některá z těchto ojedinělých témat se však místy odráží v hlavních kategoriích.

\section{Kategorie 1: Agenda a denní rutina školního speciálního pedagoga}

Tab. 1 Vlastnosti a dimenze kategorie 1

\begin{tabular}{|c|c|}
\hline Vlastnosti & Dimenze \\
\hline Administrativa, byrokracie & Nikdy - zř́dka - občas - často - vždy \\
\hline $\begin{array}{l}\text { Spolupráce } \\
\text { s vnějšími institucemi }\end{array}$ & Nikdy - zř́dka - občas - často - vždy \\
\hline Spolupráce s pedagogy & Nikdy - zř́dka - občas - často - vždy \\
\hline $\begin{array}{l}\text { Př́má práce s dětmi, } \\
\text { speciálněpedagogická péče } \\
\text { a pedagogická intervence }\end{array}$ & Nikdy - zř́ldka - občas - často - vždy \\
\hline Práce s kolektivem & $\begin{array}{l}\text { Nikdo - téměř nikdo - část z nich - } \\
\text { mnoho z nich - všichni }\end{array}$ \\
\hline Vymezení kompetencí & $\begin{array}{l}\text { U všech nevyhraněné - u většiny jasně rozdělené - } \\
\text { vždy zcela jasně vymezené }\end{array}$ \\
\hline
\end{tabular}

Náplň práce školního speciálního pedagoga je ve většině případů obdobná, nicméně liší se některými aspekty. Velkou roli v náplni práce ŠSP hraje jednak filozofie školy, tedy i to, co škola od této pozice a daného profesionála očekává, ale také to, kterými odborníky je tvořeno školní poradenské pracoviště, zda je ve škole kompletní poradenské pracoviště v jeho rozšířeném modelu, nebo ne. Zaznamenali jsme, že na některých školách působí dokonce více školních speciálních pedagogů (např. Rl, R3, R6) nebo i více školních psychologů. Respondentka 6 uvedla, že poradenský tým na škole, kde působí, čítá šest pracovníků: „Nastoupila jsem na takovou větší základní školu, kde působí více speciálních pedagogůa kde působí i spousta asistentů a máme tam vlastně 
hodně velký poradenský tým, je nás tam asi 6, co se staráme o to poradenství, každej trošku jinačím směrem. "S dalšími pracovníky ŠPP se dělí o zajištění komplexní péče. Uvádí např́iklad, že přímou činnost s dětmi v podobě speciálněpedagogické péče či pedagogické intervence nezajištuje: „Já konkrétně ne, ale jinak tam máme intervence a predměty speciální pedagogické péče..."

Všechny respondentky se shodly na tom, že velkou část práce představuje administrativní činnost - vytváření individuálních plánů, výkazů, doporučení, projektová činnost apod. Respondentka 5 ř́ká: ,.... a potom jsem do toho měla ve škole na starosti vlastně veškerou legislativu a dokumenty, takže jsem tvořila školní vzdělávací plán, pro ty děti, jako vzdělávání žáků se středně těžkým mentálním postižením u nás na škole, tvořila jsem ty individuální plány, koordinovala jsem asistenty a vlastně jsem částečně vypomáhala s koordinací individuální integrace - po staru vlastně dětí s třetím a vyšším stupněm v běžných tř́dách."

Někteří ŠSP pracují ve škole pouze půl úvazku jako školní speciální pedagogové a druhá polovina úvazku je vyplněna jinou pozicí, jako např́klad pozice běžného učitele, metodika prevence aj. (například R1, R2, R3, R6).

Další významnou částí náplně práce ŠSP je práce s lidmi. V rámci své profese pracují s dětmi nejen ve smyslu speciálněpedagogické péče a pedagogické intervence, ale také celkové podpory dětí, stejně tak jejich rodičů a jejich učitelů. Školní speciální pedagogové provádějí depistáž a školní diagnostiku, někteří vyrábějí pomůcky a shánějí další financování pomůcek z grantů a projektů ( $\mathrm{R} 1, \mathrm{R} 2, \mathrm{R} 3, \mathrm{R} 6)$, účastní se třídních schůzek, mají své konzultační hodiny, jsou přítomni u zápisů. Někteří se účastní i škol v přírodě a podílí se na akcích školy, nicméně nikdo se akcím školy nevěnuje nijak výrazně, jsou spíše účastníky než iniciátory a realizátory. Respondentka 7 se k tomuto vyjadřuje následovně: „Do toho se neženu a pokud by mě někdo do té situace dostal, tak by záleželo, co by to obnášelo, ale v tuhle chvíli se vážně ani necítím, že bych něco takového jako dělala, protože pořád cítím, že se potřebuju orientovat tady a získávat ty zkušenosti tak. Samozřejmě, kdyby mě požádali, tak bych to asi zvážila, podle toho, jaká by to byla práce, kolik by toho bylo, aby mĕ to neomezovalo jakoby tady v téhle. "Respondentka 3 má nad rámec svého úvazku také kroužek logopedie a speciální hodiny grafomotoriky v první třídě, taktéž vede edukační skupiny pro předškoláky.

Dotazovaní ŠSP se shodují na tom, že práce neustále přibývá, zejména administrativy, a hodin vyhrazených pro práci s dětmi je málo. Taktéž se shodují na tom, že nejvíce pracují s dětmi s SPU, viz např́klad výpověd' informantky 1: „Máme tady aji hodně dětí s Aspergerovým syndromem, autismem, ale hlavně to gró jsou ty děti s poruchami učení." Respondentka 7 doplňuje: „Tady samozřejmě nejvíce dětí je se specifickýma poruchama učení, samozřejmě děti s ADHD a poruchami autistického spektra, ale těch poruch učení je tu nejvíc..." Někteří ŠSP (např́klad respondentka 4) uvedli, že jejich náplní práce je metodické vedení asistentů pedagoga (podobně R5). Dále patří do jejich pracovní rutiny spolupráce s PPP a SPC, případně s dalšími institucemi, 
např́klad s OSPOD. Důležitý je také dialog s vedením školy. Respondentka 4 dále uvedla, že je přítomna u zápisů, kde poskytuje poradenství rodičům: „U zápisu, máme takovou speciální pozici, protože vlastně děti, které mají odklad, tak máme takové speciální stanoviště, kde ještě s jednou kolegyní, která má také specku, tak poskytujeme takovou poradenskou podporu. Radíme těm rodičům, jak postupovat dál, nebo když jsou nejistí a na vážkách, tak to stejné.“

Práci s kolektivem a klimatem třídy, potažmo školy, přenechávají většinou školním psychologům. Respondentka 2 však práci s kolektivem uvádí jako svou náplň práce: „... zrovna ted'ka si píšu s kolegyní podklady pro projekt, aby nám dala pedagogicko-psychologická poradna peníze, z ministerstva samozřejmĕ to jde, na podporu tř́dního kolektivu, programy proti šikaně, ale to už je samozřejmě spíš ten metodik, ale ono se to nevylučuje. Když funguje kolektiv, tak prostě dítě, které má nějaký handicap, to zvládá líp, než když by se proti němu všichni postavili.“

Můžeme tedy shrnout, že práce ŠSP ve většině případů zahrnuje administrativní činnost, spolupráci s externími institucemi, spolupráci v rámci školního poradenského pracoviště a v rámci školy, zajištování pomůcek, depistáž a přímou práci s dětmi, konzultace s učiteli, komunikaci s rodinami žáků, dialog s vedením, přítomnost u zápisů, třídních schůzek a přijímání asistentů pedagoga a jejich metodické vedení, dále také účast na poradách pedagogů a poradách školního poradenského pracoviště. Do života ŠSP patří také rozšiřování profesních kompetencí a účast na nejrůznějších školeních a výkladech nové legislativy. Téměř všichni se shodují, že mají více či méně vymezené kompetence a rozdělené činnosti v rámci školního poradenského pracoviště, například respondentka 6: „Tím, že my jsme celý ten tým, tak si myslím, že to máme fakt rozdělený tak, jak to má být, že každý z nás má ten svůj kousek, kterým tam přispívá do toho mlýna, takže v mém případě si myslím, že to je tak, jak to má být.“ Toto ale nesdílí respondentka 5: „... my tam ty kompetence nemáme vymezený, každý, na co se cítí mít síly nebo je potřeba to udělat pro to společenství...; ...většinou se tam najdou zodpovědné duše, co i když se na to necítí, tak to vnímají, že to je potřeba. Spíš se děje to, že se na různých věcech podílí víc lidí a neví o sobě, nebo se nepotkají a mají na to různé názory, takže se některé věci protahují...; ... tak si myslím, že tam tu strukturu nemáme zatím pořádně ukotvenou tak, aby fungovala. ... ale možná umět použít tu sktrukturu jako nástroj, ne jako dogma, ale jako nástroj, tak to si myslím, že je něco, co tam furt hledáme. ... a to mi prijde, že to nám tam trpí, možná to není na základě té struktury, ale díky tomu, že na to není vlastně neustále čas, protože ta hlavní práce je o něčem jiném. Ale tohle je to zázemí, které kdyby se podařilo jako si nastavit, tak je to... jako když si zaběhnete do čistého prostoru pracovat, a ted' nemyslím jako uklizeného pořádkově, ale jinak, no..."

Na závěr této kategorie uved'me sdělení respondentky 6, která vystihuje podstatu činnosti školního speciálního pedagoga: ,.... aby se to dítě v té škole cítilo dobře, i když má nějaké omezení a nějak s tím bojuje, tak aby vědělo, že i když s něčím bojuje, tak na to není samo, že tam je ten rodič, ten učitel, že tam 
je ten poradenský tým a že se může obrátit na X lidí, kteří každý mu můžou něčím přispět....

\section{Kategorie 2: Identita školního speciálního pedagoga}

Tab. 2 Vlastnosti a dimenze kategorie 2

Vélka praxe
Předchozí praxe ve školství
Spokojenost v profesi, naplnění
Předchozí zkušenosti ve školství
jako pozitivum
Vliv předchozí zkušenosti
z jiné pozice ve školství

\section{Dimenze}

Nedůležitá - středně důležitá - velmi důležitá

Nikdo - téměř nikdo - část z nich - mnoho z nich všichni

Nikdo - téměř nikdo - část z nich - mnoho z nich všichni

Nikdo - téměř nikdo - část z nich - mnoho z nich všichni

Negativní - problematické - neutrální - vítané -

velmi pozitivní

Kategorie Identita školního speciálního pedagoga je velmi rozsáhlá a spadá do ní mnoho témat. U každé z respondentek rezonovalo něco jiného, ale přece jen tyto myšlenky něco spojovalo, a to především, že vše směřovalo k osobě školního speciálního pedagoga. Ne k jeho povinnostem a pracovní náplni, ale k jeho představám o pozici, názorům, vlastnostem, praxi, zkušenostem apod.

Ve výzkumném souboru se objevili jak profesionálové s více než deseti lety praxe (například R3), tak mladí a méně zkušení pracovníci, kteří své zkušenosti teprve sbírají (R6, R7). Co se týče praxe, obecně ve školství je možné sledovat ještě další rovinu, např́klad předchozí praxi v pozici řadového učitele, asistenta pedagoga, vychovatele apod. (R1-5, R7), nebo můžeme pohlížet na délku praxe pouze v pozici ŠSP. Nicméně všichni, kdo mají předchozí praxi i na jiných pozicích ve školství, své zkušenosti vítají a nevidí v nich žádná negativa, spíše naopak. Respondetka 1 vnímá svou pozici vưči ostatním pedagogům dobře, nevnímá žádné problémy a předchozí zkušenosti vnímá pozitivně: „Já to možná díky tomu, že jsem s nimi učila, tak teda nevnímám. Já se teda zase snažím být jako v jiné pozici...; Nene, spíš to byl přínos; ... já se cítím jako být úplně jedna z nich. Já jsem tady učila vlastně. Já mám to štěstí, že jsem tady vlastně nejdřív učila ... takže já nejsem nikdo, kdo by přišel z vnějšku, tím pádem já tu svoji pozici vnímám pozitivně, že znám tu práci z druhé strany, znám se se všemi, znám to i jako z pozice učitelky." Respondentka 2: „.... já teda musím říct, že mám teda jako velkou zkušenost praktickou, protože jsem učila na základní škole při dětské nemocnici ... 20 let jsem tam pracovala ... já jsem potom začal- dělala jsem si i psychoterapeutický výcvik, takže pracuji- i jako poradenství dělám, tudíž v tomto směru to využíám i tady, takže mě opravdu nedělalo problém ze začátku mluvit s dětma, mluvit s rodiči, vést rozhovory, komunikovat s i vyučujícími ... ale ten speciální pedagog, víceméně to 
bylo nad moje očekávání, protože jsem zjistila, že tady můžu tu svoji praxi, tu pedagogickou - teda tu terapeutickou - využít, a hlavně z toho čerpám. Fakt jako - to bylo pro mě veliké plus. "Respondentka 4: ,... ano, spíš si to myslím, že to je plus... že si to dokážete představit, jak to v té výuce jde a co se ještě dá realizovat... Myslím, že tam mám dobrou pozici. Dobře spolupracuji a myslím, že máme dobré vztahy s těmi kolegy ... ale myslím, že to je taky dáno tím, že jsem vlastně nenastoupila jako speciální pedagog, ale nastoupila jsem jako běžný učitel a oni ví, že jsem jeden z nich a až po nějaké době jsem nastoupila na tuhle pozici.“

Informantky také hovořily o naplnění z vykonávání dané profese: „... anebo je to tím, že jsem se v tomhle našla..." (R1); ,... ale já si zase uvědomuju, že jsem se na toto místo dostala v pravý okamžik svého života, že si to můžu uživat a nic mě moc neomezuje. “(R2); „Jako nedokážu říct, jak vnímám... už jsem stará na to, abych si uvědomila, co chci. Já jsem spokojená..." (R3); „Myslím, že obecně jsem asi hrozně spokojená s celkovou tou prací a pozicí... “(R6); „Naplňuje, to je špatné slovo, baví je lepši." (R7).

V rámci této kategorie respondentky také hovořily o nejistotě. Mnoho z těchto pozic je financováno z projektů a šablon na dva roky a nikdo neví, zda přiště budou na ŠSP finance, nebo zda se nezmění směr společnosti a ŠSP již nebudou více potřeba. Respondentka 4: „Jedinej problém nebo hlavní, co mě odrazuje, je ta hrozná nejistota, že ta práce je na dva roky a já nevím, jestli tu práci budu v září mít nebo ne... což v tomhle věku není... živím tři děti. Rozhodně to není nic jako příjemnýho. "Dále třeba respondentka 6: „Jo jo, taky mám ten půlúvazek ze šablon, tenhle rok by mi měl končit, ale říkali mi, že většinou to nemají problém to prodloužit, tak trošku se třepu, ale i tak si myslím, že by se tam našlo místo, jak jsou ty intervence nebo předměty speciální pedagogické péče, i když nevím, když by se ta moje pozice zrušila nedej bože, tak na koho a kam by to padlo, protože je toho celkem dost, no."

Vzhledem k tomu, že je tato pozice nová a neukotvená, vyjadřovaly své názory respondentky i k tomuto tématu. Většina z nich kvituje, že mají volnou ruku, jsou svobodné a nic je nesvazuje, práce je pestrá, na druhou stranu chybí někdy struktura a řád a někdo, na koho by se v případě nejasností a pochyb mohly obrátit. Některé z respondentek také upozorňují na spasitelský syndrom a apelují na to, že je potřeba, aby si každý uvědomil, že není možné vždy pomoct všem. Respondentka 4: „Ale prostě nemůžete zachránit všechny sami, pokud tam nemáte podporu rodiny, tak se to daří hůr̆, samozřejmě..." Respondentka 5: ,... zdravý rozum, mít od toho odstup, od všeho, co se tam děje, brát to s nadhledem... asi se nepovažovat za toho, kdo vše spasí....

Respondentky také hovořily o vlastnostech, kterými by měl ŠsP disponovat. Nejčastěji zmiňovaly empatii, otevřenost, trpělivost, ochotu pomáhat a dál se vzdělávat, komunikativní a diplomatické dovednosti, nekonfliktnost a schopnost spolupracovat. I když je ŠSP na své pozici osamocen, tedy pokud škola nemá dva tyto pracovníky, přesto musí být schopen spolupráce a mít týmového ducha, protože je členem týmu školního poradenského pracoviště 
a je také jedním ze zaměstnanců školy. Navíc významnou částí jeho práce je práce s lidmi - konzultace s učiteli, komunikace s rodiči, s poradnami, s vedením školy a samozřejmě práce s dětmi. Školní speciální pedagog je prostředníkem mezi jednotlivými účastníky podílejícími se na edukačním procesu žáků. Aby komunikace mezi danými subjekty probíhala co nejlepším a nejefektivnějším způsobem, musí být diplomatický. Toto téma však rezonovalo tak silně, že bylo koncipováno jako samostatná a stěžejní kategorie (6).

\section{Kategorie 3: Spolupráce v rámci profese školního speciálního pedagoga}

Tab. 3 Vlastnosti a dimenze kategorie 3

$\begin{array}{ll}\text { Vlastnosti } & \text { Dimenze } \\ \text { Spolupráce s poradnami } & \begin{array}{l}\text { Negativní - spíše špatná - ambivalentní - } \\ \text { spíše dobrá - pozitivní } \\ \text { Spolupráce v rámci ŠPP }\end{array} \\ \text { Spolná - spíše horší - neurčitá - spíše dobrá - dobrá } \\ \text { Negativní - horší - ambivalentní - spiše dobrá - } \\ \text { pozitivní } \\ \text { Spolupráce s kolegy }\end{array}$

Dobrá spolupráce na všech úrovních školy je pro školního speciálního pedagoga nezbytná, protože vedle administrativy zaujímá spolupráce velkou část pracovní náplně ŠSP. Kategorii bychom mohli rozdělit do několika oblastí. Informantky svorně hovořily o důležitosti spolupráce v rámci školy a školního poradenského pracoviště a tuto spolupráci hodnotí všechny jako velmi pozitivní a bezproblémovou. Výhodu některé spatřují v tom, že před nástupem do pozice ŠSP působily na škole jako běžné učitelky a znají práci učitelů i z druhé strany a vztahy s kolegy jsou pevné. Dále hovořily o fungování školního poradenského pracoviště, kde je důležité mít vymezené kompetence, ale vzájemné vztahy hodnotí velmi pozitivně a přítomnost všech členů rozšířeného modelu ŠPP vidí jako velký přínos a ulehčení. Velmi důležitá je také podpora ze strany vedení a dobré vztahy s ním. Jako důležitý aspekt označovaly také profesní sdílení, které mohou ŠSP někdy postrádat, nicméně všechny respondentky uvedly, že mají osobu blízkou, se kterou mohou sdílet. Spatřují však rozdíl mezi prostým sdílením a sdílením s pochopením a sounáležitostí. Respondentka 5: ,... takže mi někdy chybělo to... možnost sdílení toho specifika, protože jsme byli jako jinak. ... ne, že bych tady neříkala, co zažíváme nebo se oni nepodělili o své zkušenosti, ale... takové to společné, že někdo ještě řeši to stejné. Tak to jako byla taková... jako nechtěla bych říct nevýhoda. ... já bych to ted' asi přirovnala $k$ tomu, když mají rodiče... když se narodí postižený dítě ... oni nebudou řešit, jestli dítě chodí, ale to, jestli dostalo ten den epileptický záchvat, nebo ne... můžou mít kamarády, můžou to mít s kým posdílet, ale když 
nemají někoho, kdo má stejný zkušenosti, tak tam ta kvalita chybí, je to asi podobný... tak nějak.“

Další významnou oblastí je spolupráce s vnějšími institucemi, zejména s SPC a poradnami. Ačkoliv informantky reflektují ne zrovna pozitivní zkušenosti svých kolegů - běžných učitelů, samy tyto zkušenosti nevnímají negativně. Spolupráci hodnotí jako bezproblémovou, vzájemně si vycházejí vstříc. Respondentky si uvědomují těžkou pozici poraden, kdy je dětí př́liš mnoho a času a pracovníků příliš málo. S nadhledem přihlíží i k častým stížnostem učitelů, že „zprávy jsou jak přes kopírák“. Svou zkušenost vypovídá respondentka 6: „To, že někdo ř́ká, že to píše jak přes kopírák, tak to jo, to se stává, ale zase si ř́kám, že jim tam projde tolik dětí a ty čekačky jsou fakt 2-3 měsíce a oni to tam mají hrozně napráskaný, troufnu si říct, že bych do té poradny ani nechtěla jít pracovat, ale zase když po nich něco chci, takjako vždycky zvednou telefon, nebo hned zavolají zpátky a snaží se mi vyhovět, na e-maily hned odpovídají, a ještě jsem s poradnou neměla takový problém a doporučení se opakují, ale. “ Respondentka 4: „... ale ta poradna to taky nemá úplně jednoduchou pozici, když ty děti tam mají často ty diagnózy podobné a opravdu není možné vymýšlet ty obraty pořád nově a nově; ... nemůžu ř́ct obecně s poradnami. Je to o lidech... Ale vím, že tenhle psycholog je výborný odborník, tady si nejsem jistá, tenhle napíše fakt poctivou zprávu, všechno vám popíše, tenhle to má jak přes kopírák a tak dál, takže... já konkrétně s těmi nejčastějšími lidmi, s kterými komunikuji, mám výbornou spolupráci. Jako já se snažím poskytnout všechny informace co nejrychleji, když máme dítě na vyšetření, a naopak oni zase když vidí, že máme problém, potřebujeme asistenta nebo něco, tak se taky snaží a pomáhají.“ Dále názor respondentky 5: „... stav katastrofa, ale já jsem pochopila, že oni jsou zahnaní hrozně do úzkých a není to o tom. Oni vlastně nemají žádný pravomoce ... tak poslední slovo má rodič, což je v pořádku, ale je to v kontraproduktivitě pro to dítě, když si to jako ... když si to oni protlačují, tak dostávají stížnosti od rodičů a mají inspekce u sebe na poradnách a ony ty děti vidí tak málo a mají jich tolik, že to prostě... Tak mně to fungovalo tak, že když jsem věděla, co já chcu, tak mě to tam napsali, když jsem potřebovala, aby mi poradili, tak tam to nefungovalo, protože na to neměli prostor, aby mi to poskytli... to je taková služba, jako... nevím, kdyby nebyla, tak se taky nic neděje."

Dalším aspektem je spolupráce s rodiči. Respondentky ji vnímají jako vcelku pozitivní a bezproblémovou, na druhou stranu všechny hovoří o tom, že rodiče často nedbají doporučení a s dětmi doma nepracují a bez spolupráce s rodinou nelze dítěti dostatečně efektivně pomáhat.

Blíže informantky hovořily také o spolupráci s kolegy. Některé respondentky považovaly ve svém vztahu ke kolegům za pozitivum to, že dříve na škole působily jako pedagožky, tím pádem mají lepší pochopení pro učitele a vazby s nimi již mají vytvořené. Respondentka 2 kvituje svůj věk, respektive nasbírané zkušenosti, a zejména absolvovaný sebezkušenostní výcvik, který jí pomohl vytříbit komunikativní dovednosti. Respondentka 6 zvolila taktiku humoru při komunikaci s učiteli; mnoho jich také vyzdvihuje diplomatický 
přístup tak, aby učitel nebral žádost či nařízení školního speciálního pedagoga jako osobní útok či kontrolu. Roli hraje také věk - mladší respondentky (R6 a R7) nevnímají ve svém nízkém věku, a tedy i krátké praxi problém. Respondentka 2 obecně v nedostatku praxe a zkušeností spatřuje jisté riziko: „... to zapálení, že je to baví, ale někdy ty zkušenosti jsou potřeba - něčím si projít; ale věřím, že když by tuto činnost dělal někdo jako na začátku své pedagogické praxe, i mladý - věkově, toto podvědomě hraje roli, i ti kolegové to musí respektovat. Ten mladý speciální pedagog bude myslet dobře a bude mít pravdu na $100 \%$. Hraje to svoji roli, jo..."

Tématem je také zastupitelnost školního speciálního pedagoga. Někteří jsou ve své pozici na konkrétní škole nezastupitelní (např́klad R4 a R7), někteří mají školní poradenské pracoviště nastavené tak, aby všichni byli zastupitelní (např́klad R2 a R6).

O spolupráci s dalšími školami nehovořil téměř nikdo. Respondentka 7 uvedla, že jsou fakultní školou, a tedy spolupracují s pedagogickou fakultou, a respondentka 5 uvedla, že za velmi prínosnou spolupráci, vzhledem k filozofii školy, považuje kontakt s pražskou speciální školou waldorfského typu.

\section{Kategorie 4: Stres v profesi školního speciálního pedagoga}

Tab. 4 Vlastnosti a dimenze kategorie 4

\begin{tabular}{|c|c|}
\hline Vlastnosti & Dimenze \\
\hline Zdroje stresu & $\begin{array}{l}\text { Stejné - spíše obdobné - částečně stejné - } \\
\text { spíše rozdílné - různorodé }\end{array}$ \\
\hline Vliv kolektivu & Bezvýznamný - neurčitý - významný \\
\hline Strategie zvládání & Nevědomé - částečně uvědomované - záměrné \\
\hline Projevy stresu & $\begin{array}{l}\text { Žádné - spíše nevýrazné - částečně výrazné - } \\
\text { výrazné - extrémní }\end{array}$ \\
\hline $\begin{array}{l}\text { Aktivní záměrné využívání metod } \\
\text { psychohygieny }\end{array}$ & $\begin{array}{l}\text { Nevyužívají - spíše nevyužívají - občas využívají - } \\
\text { často využívají - využívají významně }\end{array}$ \\
\hline Nadhled & $\begin{array}{l}\text { Postradatelný - spíše nedůležitý - neutrální - } \\
\text { spíše důležitý - nepostradatelný }\end{array}$ \\
\hline
\end{tabular}

Stres zažívá asi každá profese, každá má také svá specifika a zdroje stresu. Každý jedinec má také své strategie zvládání, aț už si je uvědomuje a využívá jich cíleně, nebo ne. Respondentky často uváděly, že žádné vědomé strategie zvládání stresu nemají, ale hovořily o svém způsobu relaxace, regenerace a odpočinku. Většinou hovořily o aktivním pohybu, setkávání s přáteli, četbě, trávení volného času s rodinou a věnování se svým koníčkům.

Velkým zdrojem stresu je nejistota ve financování profese ŠSP. Respondentka 3: „Mně trošku vadí to, že taková je ta nejistota v tom financování. Že někdy se může stát, že ted' nebudou peníze na školního speciálního pedagoga... že jsem vždy placená z něčeho. Nejsem jak normální učitel placený státem, 
mám jakoby... myslím si něco jako grant, si myslím, na něco, na nějakou část, tak to je takový nepř́jemný. Tak to se může stát nebo já mám ten pocit, že se může stát, že se změní vláda nebo ministr školství, co se bude dívat na integraci a řekne, že budou speciální školy a já třeba ztratím práci, protože nás bude mín̆ potřeba... takže to je takový jediný, že to financování je z různých zdrojů a nevím, jestli budu mít ten úvazek, nebo ne... "Stejně vypovídají i respondentky 4 a 6, naopak informantku 7 budoucnost nestresuje, což může souviset s jejím nízkým věkem.

Respondentky popisovaly, jak se jich stres v práci dotýká, jak se projevuje a co jej zpo̊sobuje. Vedle zmíněné nejistoty je zdrojem stresu také pocit nedostatku času pro všechny očekávané úkoly a dále zvyšující se byrokracie a administrativní povinnosti. Respondentka 4 hovoří také o vnější kontrole, která se dle jejího názoru projevuje obecně ve školství: „... nevím, jestli se dá jakoby říct, šéfư, ale hodně lidí, co vás kontrolují, jako rodiče, kontrolují vás kolegové, jak pracujete, vedení vás samozřejmě kontroluje, kontroluje vás poradna, inspekce vás může zkontrolovat... je tam hodně takových lidí, co sledují, jestli ta práce je v pořádku. Takže toto. Kdybych jenom učila a věnovala se těm dětem, tak je to v pořádku, poradit rodičům, dobře, nebo učitelům... ale takhle je to výkaznictví, všechny ty plány atd. “Tato informantka dále popisuje jako stresující přiliš velké množství komunikace a spolupráce s mnoha subjekty: „... ten čas a takové to, že sedíte a ted' vám volaj... Takový to, že máte spoustu lidí, se kterými spolupracujete. “Totéž respondentka 6: „... někdy jsou dny a jdete po chodbě a zastaví vás 20 lidí a každý něco chce a na konci chodby si ř́kám... já vưbec nevím a pak druhý den ten člověk řekne: víš, jak jsem ti včera? A já... nevím prostě... a takhle na vás spousta lidí něco naháže a někdy už nechcete s někým mluvit, chcete se tak jako pročistit, a hlavně bez lidí.“

Stresující je pro ně také přepínání mezi pozicemi - některé informantky mají dílčí část úvazku na pozici běžného pedagoga, metodika prevence nebo dále působí i mimo školu v jiných organizacích. V neposlední řadě je to také přepínání mezi prací a rodinou. Pro respondentku 6 je stresovou záležitostí komunikace s rodičem. Chladnou hlavu těžko udržuje zejména v případě, že rodič nespolupracuje a o dítě a jeho školní prospěch nejeví zájem.

Stres se u většiny respondentek projevuje snahou zrychlit, byṫ někdy na úkor chybovosti. Respondentka 6 si uvědomuje, že může být někdy protivná a zpětně ji to mrzí. Respondentka 3 u sebe pozoruje při větší zátěži zvýšený hlas, další (Rl) uvádí, že ji stres nabudí k větším výkonům. Respondentka 5 pocituje větší únavu, když je ve stresu. Pro ni je také důležité mít kolem sebe lidi, kteří jsou ochotni hledat společná řešení problémů: „... že jsem si uvědomila, že kolem sebe potřebuju ty lidi, kteří chtějí hledat tu cestu..."

Protektivními prvky a zvládacími strategiemi pak jsou trávení volného času oblíbenými odpočinkovými aktivitami a sportem, trávení času s práteli a s rodinou a důležité je také zachování chladné hlavy a udržení nadhledu. Respondentka 1 uvedla: „Snažím se hýbat, snažím se chodit ven, snažím se sportovat a taky člověk jakoby stárne a začíná mít nad těma věcma nadhled, 
že si pak ř́káte, že ten stres za nic nestojí, že se tu práci člověk snaži dělat poctivě, ale pořád je to jenom práce, a to zdraví je přece jenom důležitější." Pro respondentku 2 je velmi důležité sdílení, hlavně s manželem a dcerou, která se také pohybuje ve speciální pedagogice. Neméně důležitými faktory jsou také dobrý kolektiv a podpora vedení. Stejně jako respondentka 1 zmiňuje potřebu nadhledu: „... ted' tady chodí děcka kvůli praxi, kolegyně do skř́ně, kolegové podepisovat a ted' já se potřebuju soustředit, než půjdu učit... to všechno nějak udělat, no tak nic, no, tak tady běhám... pak si musím říct, že však svět se nezboří... "Strategií respondentky 5 je pojmenování: „Mně pomáhá, když to pojmenuju, vlastně já si myslím, že do stresu se člověk dostane, když člověk nemá vyslovené své přání, své pocity a myslím, že v té chvíli jste i nejvíc čitelná i pro ostatní, takže... Mně to jako pomůže, že to jako pojmenuju a to napětí nenarůstá..." Zaměřuje se také na nejrůznější kurzy a rozvojové aktivity nejen profesní, ale i osobnostního charakteru. Učí se udržovat své hranice, jasně se vymezovat a být jasnější i pro ostatní. Učí se také respektovat ostatní, jejich názor a životní filozofii. Tato respondentka by také uvítala supervizi. Dále hovoří, stejně jako respondentky 2, 4, 6 nebo 7, o potřebě nadhledu a odstupu a také o riziku syndromu vyhoření: „... zdravý rozum, mít od toho odstup, od všeho, co se tam děje, brát to s nadhledem... asi se nepovažovat za toho, kdo vše spasí, což... což jako si myslím, že k tomu... nebo že to má, je to jako sociální oblast, tam je taky velmi snadné to vyhoření, protože tam máte pocit, že jste potřeba, a tak. Což si myslím, že je u pedagogů úplně to stejný, mít ten zdravý nadhled." O potřebě určitého nadhledu a odstupu vypovídají všechny respondentky.

Respondentka 2 pak hovoří o důležitosti vnímat sama sebe, být v pohodě, mít zázemí a cítit se dobře a radovat se z maličkostí. Respondentka 4 pak rríká, že osobní a pracovní život nelze zcela oddělit a že pokud funguje rodinné prostředí, je snazší zvládnout pracovní život: „Určitě se to prolíná, ale zažila jsem i náročnější období v osobním životě, a to je samozrejmě mnohem horší, když máte problémy v osobním životě nějaké výraznější a zůstat v práci nějak klidná a v dobré náladě a pozitivně naladěná a mít tu energii. Najít tu energii, někde ji vycucat, abyste $z$ toho měla radost nebo aby vám to přišlo smysluplný."

Závěrem této kategorie zmiňme slova respondentky 6: ,... tak jsem si ř́kala, jsi dospělý člověk, pedagog a musíš se uklidnit a nesmíš bouchnout, tak to bylo hrozně těžký, takže sebeovládání, hrozně moc, ale taky si všechno nebrat jako na sebe, některé věci jsem zjistila, že nezměníte a nesmíte z toho být smutná, že i když se snažite, tak ne vždy se povede všechno..." 


\section{Kategorie 5: Kontext společnosti a jeho vliv na profesi školního speciálního pedagoga}

Tab.5 Vlastnosti a dimenze kategorie 5

\begin{tabular}{|c|c|}
\hline Vlastnosti & Dimenze \\
\hline Připravenost pedagogů na praxi & $\begin{array}{l}\text { Nedostatečná - spíše nedostatečná - průměrná - } \\
\text { spíše dostačující - zcela dostačující }\end{array}$ \\
\hline Informovanost veřejnosti o ŠSP & $\begin{array}{l}\text { Zcela neinformovaní - špatně informovaní - } \\
\text { průměrně informovaní - dobře informovaní - } \\
\text { zcela informovaní }\end{array}$ \\
\hline $\begin{array}{l}\text { Stav inkluze v ČR } \\
\text { dle názoru pedagogů }\end{array}$ & $\begin{array}{l}\text { Zcela nezvládnutá - spíše nezvládnutá - } \\
\text { průměrně zvládnutá - spíše zvládnutá - dobře zvládnutá }\end{array}$ \\
\hline Změny v legislativě & $\begin{array}{l}\text { Vůbec nezatěžují - spíše nezatěžují - neutrální - } \\
\text { spíše zatěžují - velmi zatěžují }\end{array}$ \\
\hline $\begin{array}{l}\text { Pedagogové mají problém } \\
\text { s inkluzí }\end{array}$ & Nikdo - málo z nich - někteří - mnoho z nich - všichni \\
\hline Pohled společnosti na pedagogy & $\begin{array}{l}\text { Negativní - spíše negativní - neutrální - } \\
\text { spíše pozitivní - velmi pozitivní }\end{array}$ \\
\hline
\end{tabular}

Kontext společenského dění se velmi významně promítá do všech společenských souvislostí včetně školství, které je nuceno stále reagovat na přicházející změny a inovace. Souvisí s tím i všechny integrační snahy od roku 1989 směřující k současnému inkluzivnímu vzdělávání a potřebě profese školního speciálního pedagoga. Z dřivějšího vylučování osob s postižením do ústraní a jejich naprosté segregace společnost pomalými kroky přešla k humánním přístupům k jedincům se speciálními vzdělávacími potřebami a inkluzi. Školní speciální pedagogové, kteří tvořili výzkumný soubor, však tyto snahy považují za nepřiliš vydařené. U některých toto téma rezonovalo tak silně, že utvořilo i samostatnou užší subkategorii, nicméně téma inkluze spadá i do obecnější kategorie Kontext společnosti.

Podle dotazovaných ŠSP na inkluzi nejsou pedagogové dostatečně připraveni a ani budoucí nebo začínající pedagogy pedagogické fakulty nezvládají vybavit dostatečnými znalostmi a dovednostmi tak, aby si v praxi s tak velkou změnou dokázali poradit a změnili zaběhnutý vzorec tradiční výuky. V současnosti se stále najdou nepodporující učitelé, a ne všichni ŠSP plně souzní s myšlenkou inkluze a jsou spíše zastánci speciálního školství. Respondentka 4 o sobě ríká: „... já nejsem úplně proinkluzivní člověk“ a považuje ve své práci za nejdůležitější pomoc a podporu dětem, které se ve třídě necítí dobře: „Já si nemyslím, že tohle je úplně ideální řešení té inkluze. Protože vidím ty děti, které mají problémy s intelektem a selhávají a my sice můžeme omezit učivo, můžeme to osekat, můžeme snížit počet příkladů, snížit diktáty a všechno. Samozřejmě to sebou přináší ty důsledky, že pokud to nemají dostatečně naučené, tak ty problémy... to učivo se nenaučí líp jen tím, že zkrátíme čas. Naopak. Tak to je jedna věc a ta druhá věc je, že oni stejně 
si to uvědomují a pak záleží, jakou mají povahu. ... pokud jsou ty děti trochu citlivější, tak somatizují, bolí je břiško a tak dál, oni si to uvědomují. ... já jsem zastánce speciálních škol. Ne pro všechny, ale pro děti, které prostě se necítí takto dobře a nepomáhají podpưrná opatření natolik, aby se ten jejich pocit zlepšil, tak jsem pro." Inkluze se podle této respondentky zavádí narychlo, je nedomyšlená a naaranžovaná a daleká severskému modelu, zejména kvůli financování. Speciální školství podle ní přináší dětem možnosti, které jim běžný vzdělávací proud poskytnout nemůže. Obdobně vidí jako problematické začlenění dětí se sníženým intelektem respondentka 3: „... ale na integraci opravdu dítě se sníženým intelektem... ale měli jsme, no... ale bylo pořád poslední, a i když člověk promluví s dětma, oni jsou vnímaví, hodný, dobrý... první třída, druhá, ale potom, jakákoli soutěž nebo aktivita... prostě všecko byl problém, to dítě nikdy nezažilo pocit úspěchu, takže potom rodiče i sami naznali, že ho dali do speciální školy. Ale my otevření jsme. Ale sama za sebe si nemyslím, že je to vždy dobrý... toto je jasný, že když je tam jedna tělesně, nějaké ADHD a tak, tak to jde. Ale s tím nižším intelektem si myslím, že to dobrý není."

Téma inkluze velmi rezonovalo u respondentky l, která říká, že dochází k přehlcení podpůrnými opatřeními často na úkor průměrných dětí i dětí nadaných. Vypovídá dále o zkušenosti s dvojakým př́stupem učitelů: ,... jak jsem zažila na jedné škole, kde je chlapec ... je teda na vozíčku, rozumově, i když se to moc neprojevuje, je na tom velice dobře, špatně teda mluví a ta maminka si našla přimo nějakou školu a z jejího pohledu je strašně spokojená a nadšená, a když se za ní teda zavřely ty dveře, ty učitelky kolegyně pak řeknou ,stejně skončí ve speciální škole, tady nemá co dělat', tak to mi přišlo jako takový zvláštní, taková dvojakost." Tato informantka také hovoří o tom, že jejich škola je inkluzi velmi otevřená, zkušeností mají mnoho, ale další nové zkušenosti stále očekávají a vítají. Podobně jako zmíněné informantky hovoří i respondentka 5, která považuje integraci za vhodnou, pokud je oboustranně prospěšná. Upozorňuje navíc na potřebu jednotného přístupu školy a rodiny. Zároveň reflektuje nárust zbytečné byrokracie: „Pardon, ale když jde v dnešní době hlavně o ten papír, když to tak řeknu, a nikdo si to nečte."

Respondentka 6 hodnotí, že inkluze je větší problém pro starší učitele, s čímž ne zcela souhlasí respondentka 7, která naopak uvádí, že učitelé s mnohaletou praxí mají mnoho zkušeností, které mohou využít: „U těch dětí s poruchama učení, opravdu mám tady staré praktiky, kteří ví a nedělá jim to problém, anebo dělají taková cvičení $v$ těch třídách, kdy hodně tady těch dětí, co mají oslabenou sluchovou a zrakovou percepci, tak hodnĕ si myslím, že těch poruch rozvíjejících, mohou eliminovat, protože to s těmi dětmi docvičují, pořád. A používají ten bzučák nebo jiné pomůcky." Respondentka 6 dále pozoruje větší problém s inkluzí u pedagogů-mužů: ,... musím říct, že s tím mají problém většinou chlapi, oni to nějak, přece jenom ty ženský jsou takový mateřštější, tak to pro to dítě chtějí udělat, i když mají nějaký problém nebo poruchu, ale ty chlapi to berou tak, že ty jsi něčím zvláštní, tak patříš 
do nějaké zvláštní školy nebo tak, takže pro ně je to takové horší no... "Respondentka 2 hovoří o pedagozích určitých oborů: ,.... ted' úplně stř́lím, může to být matikár̆, fyzikár̆. Tam je to myšlení jakoby trošku jiný, tam to nejde do té psychologie, zaměření humanitního. ... Ale to je tím, že oni nemají přehled a třeba jim to doma funguje a nemají takový to empatický nastavení, že tady tomu dítěti to nemusí fungovat, i když jinde to funguje. Ale to nemá cenu s nima jít do nějakýho konfliktu. Když člověk pochopí, jak oni to mají, tak ono to nevadí.“

S inkluzí přibývá také administrativa, což zmiňují všechny oslovené ŠSP. Zvyšují se tak nároky nejen na vedení školy, ale zejména na učitele, kteří již nejsou schopni vše plně zajistit, proto vzniká stále silnější potřeba odborného pracovníka: ,... pokud je to dobře nastaveno, tak je to velice důležitý ... myslím, že at' jmenujete děti, rodiče, učitele... prostě všichni jsou jako za speciálního pedagoga vděčni, protože i ty učitelé jsou jako rodiči... někdy se vám tam něco objeví a klidně se přijdou zeptat co a jak s tím, takže je dobře, že to vzniklo."(R2); ,...já si myslím, že i jako ted' je to vnímáno společností dobře, že... dneska fakt těch dětí s těmi poruchami přibývá. Těžko říct, jestli přibývá nebo jestli máme lepší diagnostiku. To je druhá věc, že se to neřešilo až tak. Ale určitě jich přibývá, protože... zdravotní hlediska a tak... si myslím, že přibývá. Ale řekla bych, že dobře, protože fakt, fakt... je to ted'ka takové moderní a teprve nyní to začíná být takový potřebný. “(R3); ,... dokud to lidi budou potřebovat, tak důležitá je." (R5). Také respondentka 6 ř́ká, že by se jejich škola kvůli integraci bez ŠSP neobešla, ovšem pro veřejnost může být školní speciální pedagog stále záhadou: „Hodně mě hází do pytle s psychology rodiče, i někteří učitelé, alespon̆ ze začátku to tak hodně bylo. Ale jakmile se dostanou k vám blíže, tak si uvědomí tu práci školního speciálního pedagoga."

Ruku v ruce s inkluzivními tendencemi jde i změna legislativy, která způsobuje zmíněný nárůst nutné administrativní činnosti. Respondentky uváděly, že neustálé změny a důsledky těchto změn jsou velmi vyčerpávající, nehledě na to, že ani školitelé si nejsou výkladem nových vyhlášek zcela jisti a znají je pouze teoreticky, ale aplikace do praxe je věc odlišná: „... že co se týče možná té legislativy, pořád se dějí různé změny a my se snažíme chodit na všechna školení, ale často ti školitelé ani jako... nějak se to uvede do praxe a oni hned dají školení, ale ještě to není tak zapracované, aby vám řekli, že ted' se to dělá takhle a třeba nefunguje to úplně, je to lepší udělat jinak, dělají to tak teoreticky a někdy sami nevíme, musíme hledat, co se změnilo a tak dále, a mění se ty tiskopisy, co máme, ty individuály tím, že vyškrtnou jeden řádek a vše musíme predělávat, takže kdyby se to dostalo někam nahoru, tak je prosím, aby s tou legislativou pořád takhle nešachovali, protože nás to zaseká a fakt bychom se rádi věnovali těm dětem, a ne prohlížení papírů, to mě fakt vytáči." (R6).

Neustálých změn se respondentky také obávají s ohledem na financování jejich profese. Mnoho ŠSP je financováno z projektů a šablon.

Co se společnosti týče, už jsme zmínili potřebu společnosti mít ve svých řadách školní speciální pedagogy. Ti ovšem často vnímají negativní postoj společnosti vůči pedagogům obecně: ,... to mě vždycky jako mrzí, že to spoustu 
lidí jako nevidí. Nevidí do té práce a hodnotí jenom ty prázdniny, a že končíme ve 12, ale ono to není ve 12, že jo... a já... já na obědy nechodím, ale nevím, jestli bych to stíhala. Nestíhala. ... Já mám zkušenost, že mám pocit, že když člověk řekne, že dělá speciálního pedagoga, že to zní líp, než když je učitelka. Pro zasmání teda, ale..." (R1); „Trošku mi vadí pohled společnosti, jak na učitelku, tak na učitele obecně. Nevím, kde to vzniklo, kdy to vzniklo.“(R3); ,... někdo nadává ,vy máte tolik dovolené, tak nevidí to zatím, tu psychickou práci během roku, že to fakt vyčerpává ... a že když mám dovolenou, tak to znamená, že mám dovolenou a že z toho, že se to jmenuje prázdniny a že jsou pevně daný v rámci a že jindy tu dovolenou si nemůžu vzít, relativně, když bych chtěla...“ (R5). Informantka 6 dále vypovídá, že pozitivní zpětná vazba přichází málokdy, ale v případě nespokojenosti se neváhají rodiče ozvat a jako první vše schytá třídní učitel, at' už se rodič zlobí právem, či nikoliv. Na druhou stranu se podle respondentky rodiče o své děti př́liš nestarají a nepracují s nimi a intervence školy je mnohdy až obtěžuje. Nezájem rodičů vnímají i ostatní dotazované. Stejně tak hodnotí respondentka 6 jako velmi nevděčnou pozici asistenta pedagoga. Sama říká, že by tuto pozici zastávat rozhodně nechtěla, ale vnímá, jak moc jsou tito lidé potřební. Respondentka 2 zase ř́ḱá, že asistent mnohdy nese tíhu celé inkluze. Respondentka 6 se dále pozastavila nad tím, že se pedagogové dětí bojí: „.... jakože půjdu do té školy a ted' tam budou ty děcka a některý budou fakt krutí, tak jsem byla obrněná a říkala jsem si, že ne, nesmí mě dostat, ale jako bála jsem se jich, jako dospělej se bojí dětí. ... a pak vidíte ve škole, jak tamhle učitel dostane facku, tak jdete do té školy a říkáte si, odkud to přijde. "Obdobnou zkušenost má i respondentka 3, která vypovídá o zkušenosti, kdy se vyučující obávala reakce rodičů: „... že paní učitelka měla strach z rodičů ... že rodiče některých... ta speciální pedagogika, že když má dítě poruchu učení, rovná se, že je to blbeček, což není vůbec pravda... Ty rodiče si mysleli, že už to dítě bude zaškatulkovaný jako blbeček."

Školství se snaží odrážet ideály společnosti a reagovat co nejpružněji na změny, které přicházejí. Respondentka v tomto směru hovoří například o krizi rodiny, na kterou je potřeba ve školách také reagovat a pomoct dětem nejen se školním prospěchem, ale i s těžkostmi, které přichází z rodinného prostředí. To ovšem klade na pedagogy stále větší a větší požadavky, přestože je zřejmé, že vzdělávání a výchovu nelze nikdy zcela oddělit. Nová doba také přináší nové možnosti a nové technologie, které mohou být jak přínosem pro výuku, tak problémem. Respondentka 3: „... ted' je fakt výhoda těch tabletů a té technologie. Přijdeme k něčemu, čemu nerozumíme, děti neznají nebo neznaly, tak hledáme ... máme v každé tř́dě interaktivní tabuli, takže práce teda s interaktivní tabulí, tam je spousta materiálů různých a děti to teda baví. I když nejsem úplně zastáncem tady takových těch elektro vymožeností u jakoby... občas do výuky se mi to líbí, ale ne pořád, to si myslím, že pro děti s poruchami učení to dobré není."

Respondentka 5 hovoří o neschopnosti tvořit v dnešní době společenství a apeluje na to, že je ve společenství, jímž škola bezpochyby je, nutné 
respektovat druhé a být zodpovědný za to, že jsem se třeba k něčemu sám nevyjádřil, a přijímat tedy i následky, které z toho plynou. Reflektuje také, že se společnost neustále vyvíjí, vyvíjí se i její směr, ale že se zároveň vyvíjíme i my samotní. Aby společenství (nejen školní) bylo bezproblémové, měl by podle respondentek školní speciální pedagog být diplomatem a prostředníkem či spojovatelem nejen mezi učitelem a dítětem, mezi školou a rodiči, ale také mezi školou, potažmo učiteli, a vnějšími institucemi, jako jsou PPP, SPC či OSPOD a mnohé další, ale i mezi společností a jejími vizemi a školou, jakožto realizátorem těchto vizí.

\section{Kategorie 6: Být diplomat}

Tab. 6 Vlastnosti a dimenze kategorie 6

\begin{tabular}{|c|c|}
\hline Vlastnosti & Dimenze \\
\hline Být diplomat & $\begin{array}{l}\text { Nedůležité - téměř nedůležité - částečně důležité - } \\
\text { důležité - velmi důležité }\end{array}$ \\
\hline Schopnost spolupráce & $\begin{array}{l}\text { Nežádoucí - spíše nežádoucí - částečně žádoucí - } \\
\text { spíše žádoucí - velmi žádoucí }\end{array}$ \\
\hline Vlastnosti pracovníka & $\begin{array}{l}\text { Nelimitující - spíše nelimitující - částečně limitující - } \\
\text { spíše limitující - velmi limitující }\end{array}$ \\
\hline Nadhled & $\begin{array}{l}\text { Nevědomý - spíše nevědomý - } \\
\text { částečně uvědomovaný - spíše uvědomovaný - } \\
\text { velmi uvědomovaný }\end{array}$ \\
\hline Role prostředníka & Ojediněle - ne př́liš často - občas - často - neustále \\
\hline
\end{tabular}

Kategorie Být diplomat rezonovala téměř u všech respondentek velmi silně. Zahrnuje několik témat, jako jsou potřebné předpoklady pro práci školního speciálního pedagoga, přístup k zaměstnání, role pracovníka a způsoby komunikace školního speciálního pedagoga.

Respondentky velmi často hovořily o nutnosti jednat diplomaticky jak ve vztahu k vedení školy, tak k rodičům, ale nejvíce ve vztahu ke kolegům. Hledají cesty a jemné nuance, jak s kolegy hovořit a sdělovat jim požadavky a případnou kritiku tak, aby si tato sdělení nebrali osobně nebo jako útok, ale aby je vnímali jako pomoc od odborníka, který se snaží pomoci dětem a zvýšit úroveň vzdělávání a pozvednout pověst školy. Často musí volit speciální taktiky. Respondentka 1 uvádí, že kolegům předem chystá materiály, které by mohli využít, aby její intervenci vnímali jako pomoc. Vždy si situaci nejdříve promyslí a přichází rovnou s konkrétním návrhem a opatřením. Nechává učitele, aby sami přicházeli a řekli si, co potřebují. Respondentka 2 využívá při komunikaci s učiteli, ale i s rodiči a žáky své zkušenosti z předchozích zaměstnání a zejména z psychoterapeutického výcviku, který absolvovala a díky němuž dokáže vést dialog a kolegy „zpracovat“. Také uvádí, že je nutné si u kolegů vybudovat svou pozici, respektovat je a že nemá cenu jít s nimi do konfliktu. V tomto směru zmiňuje i faktor věku, který spolupráci velmi 
ovlivňuje. Taktéž respondentka 4 říká, že nemá smysl „lámat věci přes koleno“ a snaží se, aby byli vždy všichni co nejvíce spokojeni. Individuálně případ od případu řeší nejen žáky, ale i pedagogy: ,... každý máme něco, co je nám příjemného nebo nepř́jemného. Lidé jsou různí a je potřeba, aby se také v té práci cítili dobře. A pokud by to měli, jakože já mám nějakou představu a ted' ji budu uplatňovat za každou cenu a budu chtít, aby se ten učitel ve všem přizpůsobil, tak to nejde... Pokud vidí ti učitelé, že se snažíme, že se to snažíme skloubit, aby byli všichni spokojení, tak prostě to je nejlepší..." Podle respondentky 5 nelze ani všechny rodiče brát stejně, i zde je potřeba individuální přístup a hlavně pochopení, zejména u rodičů dítěte s hendikepem. Podle ní je potřeba být diplomatický i ve směru k sobě samému. Najít si cestu, která nám samotným nejvíce vyhovuje, najít si čas na sebe, budovat svou pozici, vzdělávat se a hledat nové cesty, ale zároveň se umět vymezit a udržet si své vlastní hranice. Informantka by uvítala ve školství povinné supervize. Při jednání s rodiči by bylo velice užitečné absolvování psychoterapeutického výcviku: „... ty rodiče už ani nemají ty síly nebo cokoli dál řešit nebo mi připadne, že by tam spíš člověk potřeboval mít psychologický vzdělání, když tam dělá tu pedagogiku, skoro terapeutickou pro práci s těmi rodiči. Být tam ten terapeut, ten psycholog by tam měl bývat, nebo ta škola by ho měla mít pro ty rodiče, když bychom se dívali na tu komplexní péči..." Respondentka 6 využívá pro jednání s kolegy strategii humoru: „Já to beru tak, nebo jsem si to v práci nastavila tak, že když už po těch učitelích něco chci, tak to napíšu tak jako trošku s humorem, třeba ted' před Vánocema jsem odesílala zase restovej e-mail, co mi kdo dluží a kdo to neodevzdá, neuvidí zlatý prasátko a oni na to konto každý napsal nějaký vtípek a pak mi posílali ty resty... Zároveň uvádí kolegům deadline vždy o několik dní dříve, aby měla časovou rezervu a nebyla ve stresu, protože počítá s tím, že učitelé nestíhají a nepřinesou požadované včas. Respondentka mnohokrát uvedla, že se cítí jako hlídací pes a neustále jen „uhání“ kolegy, aby něco zpracovali. I poslední informantka si uvědomuje, že vždy záleží, jakým způsobem informace sdělí: „Záleží hrozně moc na tom, jaký s ním máte vztah a jak to řeknete. Pokud jsme nastavení na to, že se tady žádáme, že si děkujeme a že se prosíme, tak se ta kritika, nebo tady tohle, poslouchá podle mě mnohem lépe..." Respondentka 7 dále uvádí, že ale ne vždy tyto strategie fungují: „... ted jsem si vybavila dokonce jednu situaci, kterou jsem musela řešit, nebylo mi to př́jemné a dlouho jsem s tím bojovala a snažila jsem se něco dělat i pro to, jestli bych se tomu mohla vyhnout, jestli by to nešlo jinou cestou. Nešlo to jinou cestou a musela jsem vyloženě na toho učitele nastoupit, ale vzal to. A i když byl hodně starší, tak to vzal a funguje to. Ale jakože, co jsem kontrolovala, tak ze začátku jsem kontrolovala dennĕ, hodně, pak jsem to trošku popustila...“ Nutnost použít vhodnou formulaci zdůrazňuje i ve vztahu k rodičům: „Neř́kám nikdy slovo ,musíme, to řeknu ted' jen vám, jim to neříkám. Říkám bylo by dobré, bylo by možné, jde to takhle, já mám zkušenost, nemůžu po nich nic chtít, když budou chtít, tak přijdou, ale nemám očekávání, že budou to doma dělat, spíš mám očekávání v sobě, to mám vyřešené tak, že to dělat nebudou. Protože 
z těch konzultací, co jsem měla, tak podle mě pracují tak $20 \%$, zbytek ne. Ale já mám svědomí čistý, já jsem pro to udělala vše. "Respondentka 4 dále uvádí, že je potřeba vše vykomunikovat tak, aby učitel chtěl dítěti pomoct: „... tak nějak to domluvit, aby tu potřebu cítili i sami, kdyžji necítí nějak přirozeně. Neměl by být konfliktní, protože je to takový ten člověk, co má spolupracovat a co má stmelovat a spojovat a být prostředníkem, aby to fungovalo, aby to šlo hladce a nehledat problémy a neukazovat problémy, spíš naopak..." Jako strategii jednání s nespolupracujícími rodiči zvolila tato respondentka názornost. Umožňuje jim, aby si se svým dítětem prožili jeho neúspěch ve třídě a pro mnohé je to podle respondentky tak silný zážitek, že s dětmi začnou pracovat i doma a lépe spolupracují se školou.

ŠSP komunikuje neustále, a to se spoustou lidí. Jak už bylo řečeno mnohokrát, komunikuje s vedením, pedagogy, asistenty pedagoga, dětmi, jejich rodiči a také s veřejností a vnějšími institucemi. Schopnost spolupráce je tedy nepostradatelná. Respondentky dále uváděly určité vlastnosti, které by měl ŠSP mít, aby mohl být ve své práci úspěšný. Takovými vlastnostmi jsou zejména empatie a otevřenost, ochota se dále vzdělávat a hledat nové cesty, nezkostnatělost, ŠSP musí mít dobré komunikační dovednosti, musí být trpělivý a ochotný pomáhat, musí být diplomatický, nevyhledávat problémy, umět je řešit a umět spojovat, slučovat a spolupracovat. Měl by se také umět ovládat a zachovat chladnou hlavu a odstup od problému. Respondentka 6 upozorňuje na to, že by se školní speciální pedagog měl držet etických zásad a respektovat hranice soukromé rodinné situace žáka, přestože jsou mnohdy informace velmi užitečné. Respondentka 7 klade důraz na to, že by měl školní speciální pedagog být zdatný ve své vlastní psychohygieně.

Pro práci je také důležité udržet si nadhled a odstup a dopřát prostor i rodičům, jak ve smyslu umožnit jim sdílení starostí, tak poskytnout prostor pro vlastní rozhodování. Pro respondentky je také důležité uvědomit si, že nelze zachránit všechny a nemá cenu se rozčilovat. Respondentka 5 hledá mezníky, kde je potřeba změnit něco na straně dětí a př́stupu k nim a kde je potřeba změnit něco na sobě samotné. Také pro respondentku 6 je důležitý nadhled, schopnost oprostit se a nemít pocit, že vše spasí, která k tomuto zjištění došla díky školitelce: „... a ona mi řekla, že to tak prostě někdy nejde, tak to byla taková ledová sprcha, ale když mi to řekla, na tom školení, tak jsem byla tak jako naštvaná, že to mám vzdát, ale když jsem pak došla domů a říkám si, a jo, ona měla vlastně pravdu, takže bychom se zbytečně trápili, když tu energii můžeme dát někam jinam..."

Svou úlohu vidí ŠSP zejména jako roli prostředníka a diplomata mezi různými subjekty. Často řeší konflikty mezi asistenty pedagoga a učitelem, musí také řešit nesoulad mezi dítětem a asistentem, ale i neshody mezi třídním učitelem a druhým pedagogem. Jsou přostředníkem mezi učitelem a poradnou, ale také mezi poradnou a rodičem. Pomáhají jak učitelům, tak rodičům porozumět zprávám a doporučením přicházejícím z poraden. Dle respondentky 4 ŠSP také zprostředkovává dítěti vědomí odpovědnosti za své 
jednání a rozhodování i odpovědnosti za vzdělávací proces a jeho výsledky: „... a ty děti na prvním stupni velmi chcou. Jako samozřejmě jsou tam děti, které maji poruchy pozornosti, pracuje se s nimi třeba výrazně hůr̆, ale často ty děti jakoby se velmi lehce motivují. Horší je pak druhý stupeň, ale tam se snažím převádět odpovědnost na ně. To znamená, každou hodinu skoro začínám tak ,je něco konkrétního, co byste chtěli procvičit? a oni už jsou zvyklí, že přemýšlí o tom, co by chtěli dělat v té hodině, co třeba nechápou a s tou myšlenkou jdou na naši hodinu a tam se tomu věnuje..." I tato respondentka na pozici ŠSP pohlíží jako na úlohu prostředníka. Úkolem ŠSP je také být mediátorem mezi učitelem a rodičem, zvláště když je jejich vztah vypjatý: „Protože jsou rodiče, kteří vyloženě nemají rádi ty učitele z nějakého důvodu, je jedno, jestli oprávněně, nebo ne. Beru to tak, může to tak být a jsou na něho vysazení. Takže reaguji na některé věci, které jim ten učitel řekne jinak, a když jim to řeknu já, v klidu a v pohodě, můžete takhle, ale nemusite, je to na vás, jestli budete pracovat, nebudete, nebo jestli to chcete, či nechcete, je to vaše rozhodnutí, tak prostě takhle to u mě zafungovalo. Takže takhle to šlo." (R7).

V neposlední řadě podle respondentky 7 je také ŠSP prostředníkem mezi školou a veřejností a vyššími instancemi: ,... i ten člověk, učitel, potřebuje nad sebou ten bič a potrebuje to slyšet, jako fakt už to musím začít dělat, někdo po mně šlape. A někomu to stačí jenom ř́ct, prijidu za 10 minut a je to nachystaný. To stačilo až odpoledne, ale tak už to máš. A někdo je takový, že to nachystá a všechno, ale v tom dodržování tady těch věcí u těch žáků s tím podpůrným opatřením dost polevuje. Nejde o to, že by muselo mít nějaké výsledky to dítě, nějaké velké nebo tak, ale jde o to, že se na to čerpají peníze ze státního rozpočtu, takže chceme, aby ta práce, nejenom že na nás někdo klepe shora, ale i chceme, aby ta práce byla odváděna pořádně a správně...

\section{Kategorie 7: Vliv školy na výkon profese školního speciálního pedagoga}

Tab. 7 Vlastnosti a dimenze kategorie 7

\begin{tabular}{|c|c|}
\hline Vlastnosti & Dimenze \\
\hline Vztahy na pracovišti & $\begin{array}{l}\text { Velmi špatné - špatné - neutrální - dobré - } \\
\text { velmi dobré }\end{array}$ \\
\hline Vliv filozofie školy na práci ŠSP & $\begin{array}{l}\text { Žádný vliv - vliv téměř žádný - částečný vliv - } \\
\text { spíše ovlivňuje - velmi ovlivňuje }\end{array}$ \\
\hline Otevřenost školy k inkluzi & $\begin{array}{l}\text { Úplné uzavření - spíše uzavření - } \\
\text { neutrální postoj k inkluzi - spíše otevření - } \\
\text { naprosto otevření }\end{array}$ \\
\hline Pracovní podmínky & $\begin{array}{l}\text { Velmi neuspokojivé - spíše neuspokojivé - průměrné - } \\
\text { dobré - velmi dobré }\end{array}$ \\
\hline Další vzdělávání pracovníků školy & $\begin{array}{l}\text { Vůbec není podporováno - spíše není podporováno - } \\
\text { ani nepodporováno, ani podporováno - } \\
\text { spíše podporováno - velmi podporováno }\end{array}$ \\
\hline
\end{tabular}


Mnohé školy si dnes už nedovedou představit, že by na nich nepůsobil školní speciální pedagog. Navzdory tomu, že ještě před několika lety tuto osobu zaměstnávala pouze hrstka škol, a i s ohledem na to, že jejich financování je stále nejisté a nevychází z rozpočtu školy, ale ze šablon, různých projektů a grantů nebo jsou školní speciální pedagogové hrazeni jako podpůrné opatření pro žáka. Financování je ožehavé téma skoro pro všechny respondentky. Toto téma se však dotýká i jiných kategorií, kde bylo popsáno více, není třeba jej tedy znovu rozepisovat.

Důležitějšími aspekty jsou například zázemí a vztahy ve škole. Všechny informantky byly spokojené na svém pracovišti, se svými kolegy i s vedením školy. Ve vedení školy cítí oporu a záštitu, a to i v případě nejistého financování pozice a respondentky věří, že by vedení zajistilo naplnění jejich úvazku jinak, pokud by byla škola nucena pozici zrušit. Respondentka 6 popisuje dobrou zkušenost, kdy za ní vedení stálo a plně ji podporovalo i v situaci narušeného zdraví a dlouhodobé nemoci a hodnotí pracovní podmínky jako nadstandardní: „Řekla bych, že asi nadstandardně, asi se do toho promítlo to, že když jsem měla nějaké zdravotní problémy... tak vedení školy vyšlo vstříc, že řekli, hele není to problém, řekni jenom, předej nějaké info, dej se do pořádku, nespěchej, my najdeme nějakou náhradu, vůbec se nezatěžuj, prostě to vypust', všichni byli tak hodní, že si myslím, že takhle by to mělo být v práci normálně, ale hrozně mi to pomohlo i psychicky, že jsem si ř́kala, že za mnou stojí v nějaký těžký moment... ale oni za váma stojí a chtějí, abyste byli v pohodě, to si myslím, že není běžný na škole nebo normálním pracovišti a hrozně si jich za to vážím za tohle."Taktéž respondentka 2 popisuje školu jako vstřícnou s dobrou atmosférou, otevřenou rodině a dětem a uvádí, že právě škola určuje kompetence školního speciálního pedagoga. Zároveň cítí oporu z vedení, které dává kompetence, důvěru a prostor k působení celému školnímu poradenskému pracovišti, kterého si řadoví učitelé váží. Respondentka hovoří takto: „... tím, že tady to školní pracoviště tak funguje, tak od toho se odvíjí fakt r̆ada věcí, že fungujou ty děti ve tř́dě, tudíž kantoři ví, co s nima a tak dál. Ale toto opravdu není o jedinci, to je o tom kolektivu; ... ale je to o tom vedení. Vždycky je to o vedení. Jak je nastavený, tak funguje celej kolektiv. To jde odshora. “ Taktéž respondentka 3 cítí podporu od vedení školy: ,... to financování toho školního speciálního pedagoga není vůbec jednoduchý. Pan ředitel, nebo... už i pan ředitel nebo i paní ředitelka tomu hodně fandí, tomu speciálnímu pedagogovi. My jsme tady teda dvě na škole. "Pracovní podmínky a záštitu vedení hodnotí jako dobré. Nejistotu cítí ve financování své pozice, ale například financování dalšího vzdělávání není problém a pracovníci jsou podporováni v dalším vzdělávání. Rovněž respondentka 5 hodnotí, že podpora dalšího vzdělávání je vysoká.

Každá škola má svou filozofii a směr. I toto se odráží v práci školního speciálního pedagoga. Mnoho škol si uvědomuje význam odborníků a snaží se zajistit rozšířený model školního poradenského pracoviště. Některé školy disponují jak ŠSP, tak školním psychologem, některé školy mají dokonce několik těchto odborníků. Dobře fungující školní poradenské pracoviště zmiňuje 
především respondentka 2, ale i jiné informantky. Respondentka 3 vypovídá o tom, že u nich je tradice ŠSP již mnoho let a jsou moderní novátorskou školou s osvíceným vedením. Pozice ŠSP vznikala na škole zejména proto, že to bylo umožněno a bylo to inovativní, nevycházelo to přímo z palčivých potřeb školy. Respondentka však vnímá, že školní speciální pedagogové jsou stále více potřeba a není v silách běžných pedagogů zajistit vše, protože žáků, kteří potřebují podporu, přibývá a s nimi narůstá i související administrativa. Filozofie školy je velmi zásadní u respondentky 5, jejíž škola vychází z waldorfské metodiky, vyučuje v epochách a klasifikuje pouze slovním hodnocením. Škola žije rytmem roku a řád vychází především z člověka. Škola také respektuje zákonitosti vývoje a člověka považují za bytost bio-psycho-sociální. Výkon není na prvním místě jako u mnohých jiných škol. Učitel je považován za vzor, který na sobě ale musí neustále pracovat. Proto jsou pracovníci podporováni v dalším vzdělávání. Škola pořádá teambuildingové akce a společné vzdělávací akce. Integraci i inkluzi jsou otevření, pokud je oboustranně přínosem. Učitelský sbor, neboli kolegium, je vzájemně vstřícný a podporující a snaží se tvořit zdravé uvědomělé společenství: ,... držíme, stojíme a rosteme dál, jako škola, tak je to dobrý. "Respondentka 7 zmiňuje, že jsou fakultní školou, a mají tedy možnost využívat často praktikanty z pedagogické fakulty. Dále se škola účastní projektu „Pomáhej školám k úspěchu“. Respondentka 2 působí taktéž na specifické škole, a to na křestanské. Obecná náplň práce je však u všech respondentek více méně stejná a odlišnosti nevychází pouze z odlišné filozofie školy, ale spíše z počtu a rozložení pracovníků ŠPP, velikosti školy co do počtu žáků a finančních možností, ale i ze vzdělání a osobnostních vlastností daného profesionála.

Všechny informantky uvedly, že je jejich škola inkluzi otevřená, ovšem osobní názor se někdy trochu liší. V otázce inkluze přihlíží k jejímu vlivu na dítě. Respondentka 4 o sobě sama říká, že není úplně proinkluzivní, kritizuje postupy v České republice, které neodpovídají vzoru severských zemí, a podporuje speciální školy: „... nemyslím, že tohle je úplně ideální řešení té inkluze. Protože vidím ty děti, které mají problémy s tím intelektem a selhávají.., že oni stejně si to uvědomují a pak záleží, jakou mají povahu. ... pokud jsou ty děti trochu citlivější, tak somatizují, bolí je břiško a tak dál, oni si to uvědomují....já jsem zastánce speciálních škol. Ne pro všechny, ale pro děti, které prostě se necítí takto dobře..." Obdobně smýšlí i respondentka 3. Respondentka 1 uvádí, že jejich škola má s integrací mnoho zkušeností a je otevřena dalším, ale obává se: ,... někdy přemýšlím, jestli není přehlcení tady těma podpưrnýma opatřeníma. Na úkor, dejme tomu, dětí nějakých průměrných nebo třeba i nadprůměrných, protože díky inkluzi bývá... ve třídě začínají být tak velké rozptyly těch dětí. Začíná to být hodně náročné na učení už." O inkluzi hovoří i respondentky 6 a 7, které se neshodnou v pohledu na to, zdali mají větší problém s inkluzí mladí, či starší pedagogové. Respondentka 7 popisuje, že učitelé s mnohaletou praxí mají mnoho zkušeností, které mohou využít a poradit méně zkušeným pedagogům. Respondentka 6 má za to, že starší pedagogové 
jsou méně pružní a nejsou na příchod dětí s hendikepem do běžných škol připraveni. Respondentky hodnotí přijetí inkluzivních tendencí i z pohledu pohlaví a aprobace pedagoga. Muži a vyučující např́klad matematiky jsou méně ochotní přistupovat $\mathrm{k}$ dítěti individuálně.

Respondentka 1, ale také 3, 6 a 7 popisují školu jako velkou, udávají okolo 700 žáků a považují prostory školy k takovému počtu žáků za nevyhovující. Respondentka 7 vyhodnocuje jako nevhodné umístění prvního a druhého stupně v jiných budovách.

Informantka 6 se zamýšlí nad složením pedagogů a považuje kolektiv spíše za mladší, respondentka 7 hodnotí kolektiv jako věkově vyvážený a vidí v tom výhodu. Respondentka 6 dále hovoří o bodovém systému hodnocení chování žáků, na kterém se ona jako školní speciální pedagog podílí: „... já jsem se s kolegyní zaměřila spíš na to chování problémové ve škole, funguje tam super systém jako bodů, pokud zlobíte, dostanete body a ty body, pokud to není velký hřích, tak se dají vymazat... když někdo něco provede, tak se může odčinit službou pro školu, někdo třeba připraví pomůcky pro mladší žáky, což je super, ... takže to dostanou zlobivci a všichni jsou spokojení, to už bylo nastavený, já jsem akorát navrhla, že můžou častěji pracovat pro ty učitele, takže nachystám pomůcky, mě tam přijdou nezbedníci a ty uděláš to a ty uděláš to, je to forma trestu. "Respondentka také řekla, že u nich na škole velmi poctivě hlídají zameškané hodiny i důsledně pátrají po příčinách náhlého zhoršení prospěchu a očekávají od rodičů spolupráci a důslednou podporu dítěte i v domácím prostředí, což je ovšem rodičům někdy nepohodlné a raději odchází na jinou školu: ,... protože my po nich něco chceme a oni si říkají, není to navíc, není to zbytečný? A tak si najdou školu ... pokud ten rodič to bere vyloženě jako obtěžování, dítě má chodit na základku, tak at si to odchodí a má klid, tak asi jsme tak vůči nim nejen já tak vysazení, že rodič to pozná a spíš to dítě někam vezme, aby měl v uvozovkách klid, jsme tam trošku takový drábové."

\subsubsection{Spolupráce jako stěžejní aspekt práce školního speciálního pedagoga (axiální kódování)}

Dalším krokem analýzy je axiální kódování. Jednotlivé kroky sice nejsou zcela odděleny, spíše se prolínají, avšak Řiháček a Hytych (2013) směřují analýzu do jednotlivých kroků pro transparentnost postupů a didaktické účely. Již při otevřeném kódování bylo zřejmé, které kategorie budou pro další postup analýzy významné a které méně.

Nyní se zaměříme na konkrétní výsek ze sítě konceptů vzniklých v předchozí fázi analýzy. Ostatní kategorie budou sloužit k definování ústředního jevu a stále budou tvořit kontext analýzy (Řiháček a Hytych, 2013). Jako potenciální cesty, kudy by se mohla analýza ubírat, byly stanoveny tyto možnosti: a) školní speciální pedagog jako diplomat, b) stres v práci ŠSP, jeho zdroj, projevy a strategie zvládání využívané školním speciálním pedagogem 
a c) spolupráce v rámci profese školního speciálního pedagoga. Všechny aspekty jsou bohatě zastoupené v rozhovorech, nicméně jako ústřední koncept byla zvolena třetí možnost, protože byla v rozhovorech velmi bohatě zastoupena, respondentky na ni reagovaly jak v odpovědích na položené otázky, tak spontánně. Zdá se tedy, že téma spolupráce je v otázce specifik profese ŠSP na základní škole velmi zásadní. Dále se tedy budeme zabývat otázkou, jak spolupráce ovlivňuje profesi školního speciálního pedagoga.

Řiháček a Hytych (2013) apelují na nutnost vzdát se snahy zahrnout do analýzy všechno, nebot' by výzkumník dostal jen obecná, povrchní a nic neříkající data s př́liš obecnými výsledky. Dle Strausse a Corbinové (1999) jsou v tomto kroku získané údaje opětovně uspořádány tentokrát novým způsobem, a to prostřednictvím vytvoření vztahů mezi vzniklými kategoriemi v rámci paradigmatického modelu, který je tvořen ústředním jevem, př́ičinnými podmínkami, kontextem, intervenujícími podmínkami, strategiemi jednání a následky. Budeme se nyní tedy zaměřovat na bližší určení jevu, a to za pomoci subkategorií - podmínek, které ho způsobují, a kontextu jakožto jeho souboru vlastností, v němž je jev zasazený. Dále také strategií jednání a interakce, za jejichž pomoci je jev vykonáván a zvládán, a také následků těchto strategií.

Po dosazení kategorií do jednotlivých položek nám vzešel následující paradigmatický model axiálního kódování (obrázek 3).

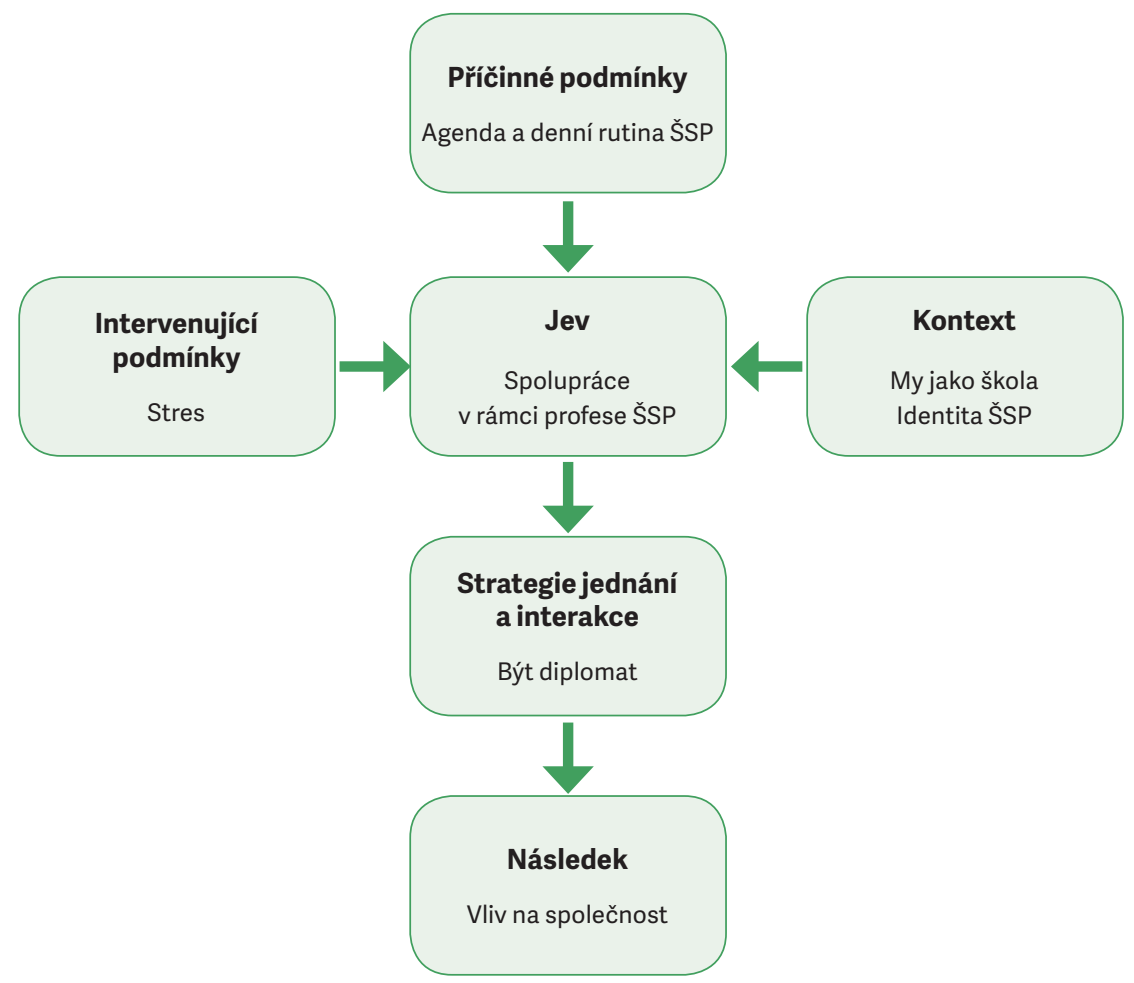

Obr. 3 Paradigmatický model axiálního kódování 
Nyní k popisu jednotlivých oblastí paradigmatického modelu.

\section{Jev}

Jev je ústřední myšlenkou, na kterou je zaměřeno jednání a interakce směřující ke zvládnutí, ovládnutí či vykonání. Bývá identifikován otázkou „Čeho se tyto údaje týkají; o čem je daná interakce či jednání?“" (Strauss \& Corbinová, 1999).

Jako ústřední jev jsme zvolili kategorii Spolupráce v rámci profese školního speciálního pedagoga. Toto téma se vyskytovalo nejčastěji napříč všemi rozhovory. Spolupráce, na níž stojí veškerá činnost ŠSP. Od komunikace s ostatními učiteli přes komunikaci s rodiči, dále komunikaci s poradnami, ale také dialog s vedením školy, dále koordinaci asistentů pedagoga a v neposlední řadě spolupráci a dialog s veřejností. Nutnost spolupráce vychází z podstaty profese a její náplně, je ovlivňována školou i školním speciálním pedagogem samotným i dalšími aspekty, jako je třeba stres a jeho zvládání. Spolupráce je podstatou profese školního speciálního pedagoga, proto tato profese vznikla, aby spolupracovala a pomáhala dětem a učitelům a mnohým dalším. Spolupráce by měla být cílem všech, kdo se nějakým způsobem podílí na vzdělávacím procesu, ale ne vždy tomu tak je a snaha o spolupráci může být odmítaná, až na obtíž.

\section{Příčinné podmínky}

Dle Strausse a Corbinové (1999) jsou to události, které vedou ke vzniku jevu. V našem případě se jedná o agendu (vč. administrativy) a denní rutinu školního speciálního pedagoga. V rámci své profese a náplně práce se ŠSP nevyhne komunikaci, jednání a spolupráci s dalšími lidmi či institucemi, mnohdy i s veřejností. Školní speciální pedagog je pedagogický pracovník, tudíž stejně jako celá škola musí reagovat na požadavky společnosti, naplňovat její vize a vést s ní konstruktivní dialog.

\section{Kontext}

Kontext je soubor vlastností, které k jevu náleží a jsou umístěny na dimenzionální škále. Je to také podmínka, za které je uplatněna strategie jednání. Definuje často intenzitu, časovou trajektorii, trvání, konkrétní umístění atp. (Strauss \& Corbinová, 1999).

Podoba spolupráce, jakožto ústředního jevu, je mj. ovlivněna školním speciálním pedagogem samotným, jeho zkušenostmi, vlastnostmi, angažovaností, postoji a názory i subjektivním vnímáním profesní role. Dále je spolupráce ŠSP definována školou, počtem a složením pedagogického sboru, zejména pak školního pedagogického pracoviště, ale také počtem žáků a jejich specifiky nebo také lokálním umístěním školy. 


\section{Intervenující podmínky}

Toto jsou podmínky, které souvisí se strategií jednání, a bud' ji usnadňují, nebo naopak komplikují a staví do cesty překážky. Jsou to obecné podmínky, které ovlivňují strategie jednání a zahrnují čas i prostor, kulturu, zaměstnání, techniku, socioekonomický status a mnohé další. Některé jsou velmi blízké, jiné méně. Intervenující podmínky ukazují, jak konkrétně je jednání těmito podmínkami řízeno a ovlivňováno, jak usnadňují či znesnadňují interakce a strategie jednání (Strauss \& Corbinová, 1999).

V našem případě se jedná o kategorii Stres. Pracovní stres je informantkami hojně popisován, stejně tak jeho zdroje a příčiny, projevy stresu, protektivní faktory, rizikové faktory a jejich strategie pro zvládání stresu. Na každou z respondentek působí stres a pracovní zátěž trochu jinak a jiným způsobem ovlivňuje jejich schopnost spolupracovat a jednat. Jedna respondentka například uvedla, že ji stres nabudí k větší výkonům, jiná respondentka cítí zvýšenou únavu. Další informantka je nevrlá, další pozoruje zvýšenou chybovost ve své práci a uzavřenost do sebe. Ve výsledku je ale vždy pozitivním nebo negativním způsobem ovlivněna strategie jednání.

\section{Strategie jednání a interakce}

Jedná se o reakce na jev, jeho zvládání za určitých podmínek. Strauss a Corbinová (1999) uvádějí, že existují určité vlastnosti strategií a interakcí. Například to, že jsou procesuální, tedy podléhají vývoji, dále autoři ř́́kají, že jde o jednání cílené, záměrné a uskutečňované z nějakého důvodu. Je to reakce na jev a pokus o jeho zvládnutí. Autoři připouští, že ne vždy musí být nutně jednání záměrné. V některých případech může jít také o reflexivní jednání. Dále autoři připomínají, že je nutné si všímat i neuskutečněného jednání. Nakonec se musíme vrátit k intervenujícím podmínkám, které jednání ovlivňují ve smyslu usnadnění, nebo naopak znesnadnění tohoto jednání.

Jako hlavní strategie jednání a interakce se vyjevila nutnost Být diplomat, což v sobě nese potřebu volit nejrůznější strategie jednání a způsoby komunikace při spolupráci s dalšími subjekty. Tato schopnost je dále podmíněna osobnostním nastavením školního speciálního pedagoga, částečně je definována školou, její filozofií i velikostí a rolí, kterou očekává od tohoto pracovníka. Diplomatické dovednosti jsou podmíněné také aktuálním stavem jedince. Ve stresových situacích je těžké zachovat chladnou hlavu a to, co by člověk v běžné situaci zvládl bez chyby, se mưže jevit jako nepřekonatelný problém.

\section{Následky}

Výsledky jednání nebo interakce, které však nemusí být vždy zamýšlené nebo předpovídatelé. I neuskutečněné jednání má své následky.

To, jak dokáže být ŠSP diplomatický, ovlivňuje mnohé. Pakliže využívá diplomatického jednání, může velmi usnadnit každodenní realitu ve škole nejen učitelům a žákům, ale často i vedení školy. Pakliže je ŠSP dostatečně 
diplomatický, může usnadnit edukační proces a práci učitele, nastavit vyšší standard spolupráce mezi školou a vnějšími institucemi, které dále pozitivně ovlivňují vzdělávací proces žáků s podpůrnými opatřeními. Mưže svým diplomatickým jednáním také změnit pohled veřejnosti na školu a může usnadnit průběh integrace či inkluze, a může se tak významně podílet na změně společnosti, na jejím směřování, na hodnotové orientaci a úrovni vzdělávání.

\subsubsection{Profesní role školního speciálního pedagoga (selektivní kódování)}

Dospěli jsme do fáze, kdy dochází k integraci vzniklých kategorií do zakotvené teorie, což je poměrně náročný proces. Strauss a Corbinová (1999) uvádějí, že se tento proces podobá axiálnímu kódování, avšak probíhá na vyšší, abstraktnější úrovni. V tomto kroku vezmeme data v jejich hrubém stavu a systematicky je budeme rozvíjet do pojmového, srozumitelného, a především zakotveného obrazu reality. Zmínění autoři uvádějí několik kroků, kterými se můžeme k takovému cíli dostat. Prvním krokem je vyložení kostry příběhu, dále uvedeme pomocné kategorie do vztahu k centrální kategorii dle paradigmatu. V třetím kroku se kategorie vzájemně vztahují na dimenzionální úrovni a čtvrtým krokem je ověřování těchto vztahů. Posledním krokem je doplnění, upřesnění a rozvinutí kategorií. V praxi tyto kroky nejsou takto striktně ohraničeny, spíše se prolínají.

\section{Identifikace příběhu (zestručnění)}

Tématem výzkumu jsou specifika profese školního speciálního pedagoga. Jeví se, že hlavním tématem napříč rozhovory je spolupráce ŠSP s dalšími subjekty, jako jsou učitelé, rodiče dítěte, dítě samotné, vedení školy a další instituce. O spolupráci můžeme hovořit právě ve smyslu s kým spolupracuje školní speciální pedagog, dále můžeme o spolupráci hovořit jako o dobré, nebo špatné, ne/konfliktní či ve smyslu konstruktivní spolupráce apod. K tomu, aby byla spolupráce dobrá a konstruktivní, musí mít ŠSP určité vlastnosti, které usnadňují komunikaci a pomáhají mu zvládnout náročné situace a zachovat chladnou hlavu i v emočně vypjatých interakcích. Takovými aspekty jsou třeba dovednosti diplomatického jednání, zachování odstupu a přistupování k práci s nadhledem, osobnostní charakteristiky jako třeba být flegmatik, dále schopnost komunikovat, vyjednávat a volit vhodné strategie k dosažení cíle. Osobnostní charakteristiky a nastavení jedince ovlivňují průběh spolupráce i vztahy s kolektivem i vnějšími institucemi. Jsou protektivním i rizikovým faktorem pro vznik a působení stresu, který vychází z pracovních záležitostí, i pro jeho zvládnutí. Osobnostní nastavení, vlastní hodnoty a postoje a názory konkrétní osoby v pozici ŠSP často odráží filozofii školy a svým přístupem a jednáním ve výkonu dané profese by mohl ŠSP ovlivňovat i společenský kontext, který je v rozhovorech vztahován zejména k osobním názorům na inkluzi v ČR. 


\section{Centrální kategorie}

Pomocí modelu axiálního kódování došlo k propojení jednotlivých kategorií. Jako u otevřeného i axiálního kódování, hledáme i nyní ústřední jev, který je nutno pojmenovat a uvést do vztahu k ostatním kategoriím. Díky metodě zestručnění příběhu jsme identifikovali kategorii, která se zdá nejvíce provázaná s ostatními kategoriemi a zasahuje do nich. Zprvu se zdálo, že touto kategorií bude opět Spolupráce. Respondentky k nutnosti spolupráce vztahovaly mnoho témat a hovořily o spolupráci velice často. Spolupráce je opravdu důležitou součástí práce ŠSP, nicméně tento pojem nezahrnuje vše potřebné. Dle Strausse a Corbinové (1999), pakliže se nenachází v seznamu našich vytvořených kategorií dostatečně abstraktní a široká kategorie, která by pojala vše, co je v příběhu popsáno, musí badatel tento ústřední jev dodatečně pojmenovat.

Pro potřeby analýzy jsme tedy vytvořili termín Profesní role. Ten zahrnuje jak očekávání a představy o profesi samotného školního speciálního pedagoga, tak požadavky a představy dalších subjektů, odráží tedy i nápln̆ práce a očekávané standardy chování a jednání. Role je dle Lintona (in Výrost \& Slaměník, 2008) aktivní stránkou statusu. Je definována jako standard chování, které od jedince určitého statusu legitimně očekáváme a vyžadujeme. Role korigují naše chování v sociálních pozicích - očekává se od nás určité chování, my toto očekávání vnímáme, interpretujeme jej a převádíme do rolového chování. Role však neovlivňují pouze naše chování, ale také názory, postoje a hodnoty (Nakonečný, 1997; Jandourek, 2001; Matoušek, 2008; Výrost \& Slaměník, 2008; Špirudová, 2015). V rámci profese školního speciálního pedagoga se také očekává určitý standard chování - profesní role, která je užším vymezením role sociální - je to soubor názorů a postojů společnosti, ale i jednotlivce $\mathrm{k}$ dané profesi.

Tab. 8 Vlastnosti a dimenze centrální kategorie

\begin{tabular}{|c|c|}
\hline Vlastnosti & Dimenze \\
\hline Přínos pro společnost & $\begin{array}{l}\text { Bezvýznamný - méně významný - průměrně } \\
\text { významný - spíše významný - velmi významný }\end{array}$ \\
\hline $\begin{array}{l}\text { Spolupráce } \\
\text { jako součást práce ŠSP }\end{array}$ & $\begin{array}{l}\text { Zanedbatelná - spíše okrajová - částečná - } \\
\text { významná - stěžejní }\end{array}$ \\
\hline Komunikační dovednosti & $\begin{array}{l}\text { Nežádoucí - spíše nežádoucí - částečně žádoucí - } \\
\text { spíše žádoucí - velmi žádoucí }\end{array}$ \\
\hline $\begin{array}{l}\text { Očekávání od profese } \\
\text { při nástupu na pozici ŠSP }\end{array}$ & $\begin{array}{l}\text { Žádná očekávání - spíše bez očekávání - } \\
\text { průměrná očekávání - částečná očekávání - } \\
\text { velká očekávání }\end{array}$ \\
\hline $\begin{array}{l}\text { Odborná připravenost } \\
\text { na výkon profese }\end{array}$ & $\begin{array}{l}\text { Nedostačující - spíše nedostatečná - } \\
\text { částečná připravenost - spíše dobrá připravenost - } \\
\text { velmi dobrá připravenost }\end{array}$ \\
\hline Spokojenost v profesi & $\begin{array}{l}\text { Velmi nespokojený - spíše nespokojený - } \\
\text { neutrální postoj - spíše spokojený - velmi spokojený }\end{array}$ \\
\hline
\end{tabular}


Nyní, když máme definovanou centrální kategorii i s jejími vlastnostmi a dimenzionálním rozsahem (viz tabulka 8), bude následovat sestavení kostry př́běhu a paradigmatického modelu selektivního kódování. Pojmy selektivního kódování by měly být na vyšší odborné i obecné úrovni, než tomu bylo v předešlých fázích analýzy (Strauss \& Corbinová, 1999).

\section{Kostra příběhu}

V centru pozornosti stojí profesní role školního speciálního pedagoga, jak z pohledu jejího nositele, tak z pohledu externího. Jak již bylo popsáno výše, i školní speciální pedagog, jako každá jiná profese, nese určitý status a roli. Status označuje pozici ve společnosti, kterou hodnotí školní speciální pedagogové jako dobrou, srovnávajíce ji s pozicí běžných pedagogů, která dle nich nemá ve společnosti tak pozitivní konotace, s čímž ale někteří vědci a autoři knih nesouhlasí. Toto tvrzení dokládají například Tuček a Machonin (1993) či Průcha (1995) ve svých výzkumech, je však nutno podotknout, že dnes již nejsou př́liš aktuální a situace v naší společnosti mưže být poněkud odlišná.

Role, tak jak ji chápe Ralph Linton (in Výrost \& Slaměník, 2008), označuje aktivní stránku statusu, tedy standard chování, které je očekáváno společností a které koriguje naše chování a formuje ho. Formují ho však také názory, hodnoty a postoje konkrétního člověka, v našem případě jedince vykonávajícího profesi školního speciálního pedagoga. Mluvíme tedy o užším vymezení sociální role, a to o roli profesní.

V rámci jedné role, zde v pozici školního speciálního pedagoga, zastává jedinec mnoho dalších dílčích rolí. Jak vyplynulo z rozhovorů, jedná se například o role poradce, manažera, koordinátora, konzultanta, ale také kolegy, někdy vedoucího pracovníka a někdy naopak podřízeného. Školní speciální pedagog je také odborníkem a zprostředkovatelem služeb nebo partnerem, také ale vykonavatelem administrativy a někdy i pedagogem s př́mou výukovou činností. Nehledě na to, že tento jedinec má i své další role mimo tuto roli profesní, jako třeba role partnera, rodiče a podobně. I mezi nimi je nutné přecházet a udržovat jejich jasné hranice tak, aby do sebe vzájemně nezasahovaly a nepůsobily komplikace.

Školní speciální pedagog by měl být schopen značné míry flexibility v přechodu mezi jednotlivými rolemi. Očekávané chování a jednání se liší vzhledem k tomu, s kým zrovna ŠSP jedná a s kým spolupracuje. Školní speciální pedagog má dle slov respondentek spojovat, sdružovat, vytvářet mosty a propojovat. Konfliktní jednání by bylo významnou překážkou v naplnění tohoto požadavku. Proto jsou kladeny na osobu školního speciálního pedagoga požadavky nejen vysokého standardu odborných kompetencí a jejich neustálého rozšiřování, ale také požadavky značných osobnostních kvalit.

Jelikož spolupráce s jednotlivými lidmi a institucemi tvoří velkou část činností školního speciálního pedagoga, jsou komunikační dovednosti a vhodné vyjednávací strategie velmi důležitým požadavkem na tohoto profesionála. Diplomatické jednání by mělo být naprostým standardem pro výkon profese 
ŠSP ve směru ke všem zúčastněným - k vedení školy, k poradenským zařízením, k rodičům a samozřejmě i samotným žákům. Především však ke kolegům učitelům, jelikož ŠSP má možnost svým diplomatickým jednáním ovlivnit přístup pedagoga k žákovi, $\mathrm{k}$ jeho individuálním potřebám, a tím i postoj pedagoga $\mathrm{k}$ integraci a inkluzi a $\mathrm{v}$ důsledku i postoj veřejnosti $\mathrm{k}$ inkluzivním tendencím, $\mathrm{k}$ pedagogické profesi jako takové, ale i ke škole jako instituci. V neposlední řadě má možnost také ovlivnit úroveň vzdělávacího procesu v zemi.

Roli školního speciálního pedagoga definuje nejen konkrétní jedinec vykonávající tuto profesi se svými konkrétními vlastnostmi, postoji a názory, ale definuje ji také škola, ve které je tato pozice zavedena, a to svými představami, filozofií a potřebami. Jelikož profese není plně etablovaná, existuje určitá míra variability v činnostech ŠSP, která je jimi hodnocena jak pozitivně, ve smyslu volnosti, pestrosti a umožnění tvořivosti, tak zde ale zároveň chybí metodické vedení, ukotvenost, řád a ujištění o správném vykonávání profese. V současné době, vzhledem ke stále probíhajícímu etablování profese a vzhledem k nedostatečnému legislativnímu ukotvení a neexistenci oficiálních standardů, utváří obraz profese a její náplň konsenzus mezi školou a osobou školního speciálního pedagoga. Škola má své představy a požadavky, odborník nabízí své pohledy, požadavky a dovednosti a společně utvářejí podobu profese na konkrétní škole. Škola ve svých požadavcích reaguje také na společenský kontext a nabídku ostatních služeb či přítomnost (popřípadě nepřítomnost) dalších institucí.

Instituce hrají významnou roli v oblasti působení ŠSP. Škola, jakožto instituce, vytváří obraz školního speciálního pedagoga a formuje jeho činnosti, do kterých spadá i spolupráce s vnějšími institucemi, subjekty a službami, s nimiž je škola povinna jednat v zájmu svých žáků a také v zájmu zvýšení kvality vzdělávacího procesu. Takovými institucemi jsou např́klad poradenská zařízení, SVP, různé podpơrné služby, může to být i veřejná správa, v určitých situacích také spolupráce s policií, OSPOD, zdravotnickými institucemi či neziskovými organizacemi. Ne všichni jsou zvyklí se školou spolupracovat, a proto mohou být navázání spolupráce a její realizace pro pracovníka poměrně náročné.

Profese školního speciálního pedagoga není hodnocena respondenty jako významně stresová, na rozdíl třeba od pozice běžného řadového pedagoga, jenž je dle dotazovaných ŠSP mnohem náročnější a stresovější. Nicméně i tak existuje určitá zátěž a stres v profesi ŠSP. Stres a jeho zdroje jsou hodnoceny různě, stejně tak i jeho projevy a důsledky nebo protektivní či rizikové faktory. V otázce stresu vždy záleží na konkrétním jedinci, jaká je u něj míra resilience, jak zdatně a zda vůbec využívá cílené psychohygieny či zda má vytvořené funkční copingové strategie.

Projevy stresu často ovlivňují jednání člověka. Často také závisí na tom, co nám stres způsobuje, co je jeho zdrojem. Pro dotazované respondentky to byl např́iklad nedostatek času, špatná organizace a plánování a následné 
nestíhání, což u nich vede například ke snaze zrychlit, a tím pádem ke zvýšení chybovosti. Zdrojem stresu je také příliš mnoho interakcí ve spojení s velkým množstvím povinností a nutnost přepínat mezi nimi.

Interakce na profesionální úrovni vyžadují od jedince značné schopnosti v komunikaci. Je nutné hledat jemné nuance a jednat diplomaticky tak, aby spolupráce vždy probíhala co nejvíce kladně, bezproblémově a dosáhlo se požadovaného cíle, což by měl vždy být především zájem dítěte.

Jednotlivé vztahy, související s pojetím profesní role školního speciálního pedagoga, jsou transparentně vymezeny v následujícím paradigmatickém modelu (obrázek 4).

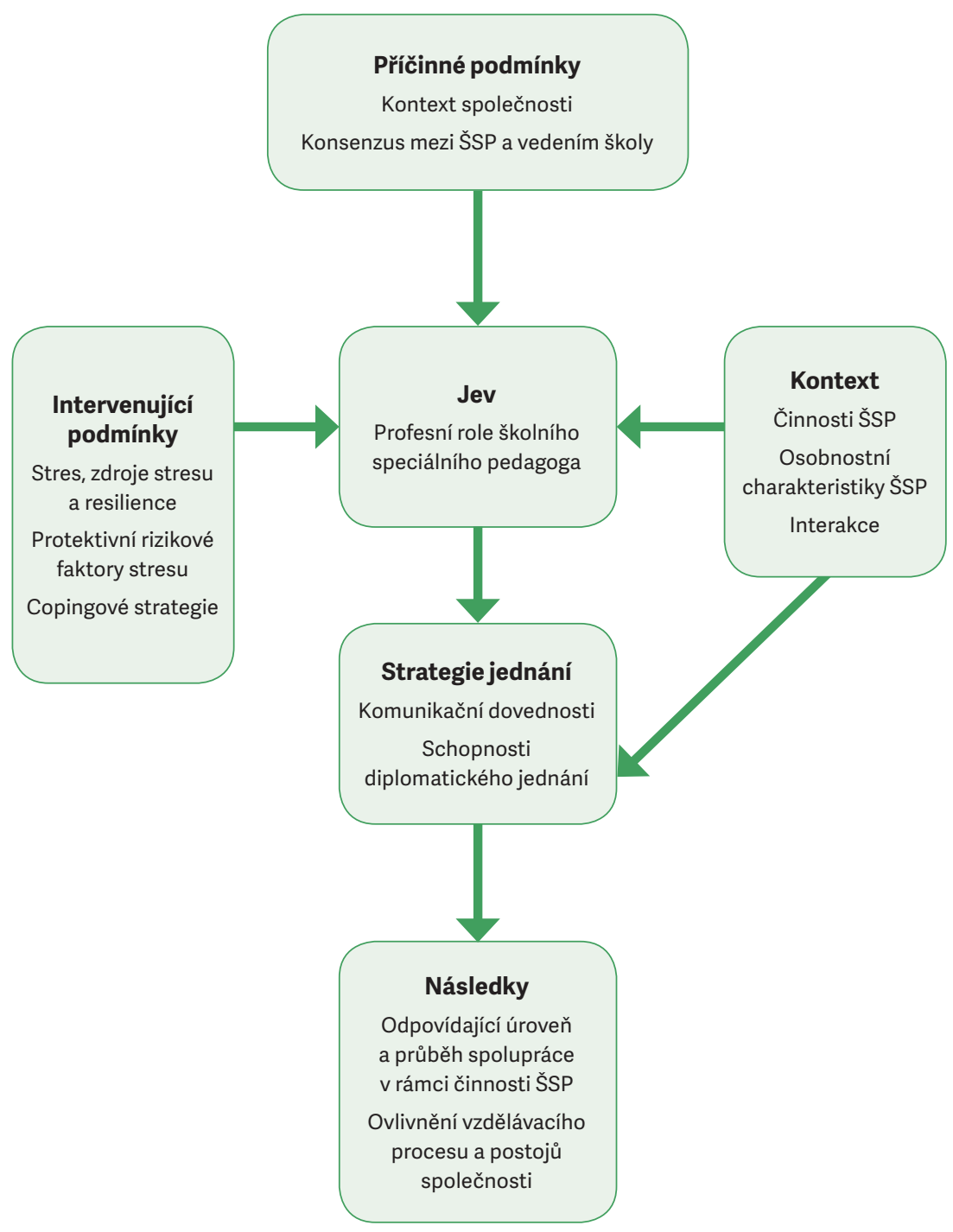

Obr. 4 Paradigmatický model selektivního kódování 


\section{Hypotetický výrok a ověření vztahů}

Podoba profesní role školního speciálního pedagoga je podmíněna externími požadavky a společenským kontextem a dále také konsenzem mezi konkrétním ŠSP a konkrétní školou. Potřeby školy spolu s osobnostními charakteristikami ŠSP a interakcemi vyplývajícími z činnosti ŠSP a dále spolu s vlivem stresových faktorů působících na jedince a jejich zvládání ovlivňují schopnost jedince v pozici školního speciálního pedagoga aplikovat komunikativní dovednosti a diplomaticky jednat s jedinci či institucemi. Prokázanou schopností diplomacie a komunikační zdatnosti ovlivňuje ŠSP kvalitu a konstruktivnost spolupráce, a tím ovlivňuje pozitivně nebo negativně postoj společnosti i samotný edukační proces.

Na základě tohoto předpokladu jsme se vrátili k sesbíraným datům a v údajích ověřovali, zda výrok platí. U některých informantek bylo potvrzení výroku velmi zřejmé, u některých bylo méně výrazné. Došli jsme však k závěru, že výrok platí v širším kontextu pro všechny zkoumané osoby.

\section{Proces aneb od jevu ke strategiím}

Důležitým krokem analýzy dle Strausse a Corbinové (1999) je začlenění procesu, který považují za základní rys zakotvené teorie. Již během předchozí fáze (axiálního kódování) byly znatelné jisté pravidelnosti a opakující se vztahy.

U všech informantek bylo zřejmé, že jejich psychický stav ovlivňuje jejich výkon. Míra stresu pramenícího z činností ŠSP ovlivňuje schopnost komunikovat a vyjednávat a ovlivňuje míru chybovosti a úspěšnosti v počínání školního speciálního pedagoga. Pakliže je míra stresu významná, negativně ovlivňuje činnosti školního speciálního pedagoga a jeho výkony. Míra subjektivně vnímaného stresu ale závisí na osobnostním nastavení a životním přístupu k práci a k řešení problémů, dále závisí na obecné odolnosti jedince vůči stresu, ale také na aspektech, jako je adekvátní možnost profesního sdílení či vhodné rozložení kompetencí do školního poradenského pracoviště. Významný vliv má také prostředí školy a zázemí, které vedení školy poskytuje. V otázce stresu je také významným faktorem schopnost a dovednost zvládat stres a aktivně využívat prvků psychohygieny v rámci své profese, ale také v osobním životě a v neposlední řadě také aktivně vytvářet a vědomě využívat funkční copingové strategie.

Konkrétní stav v konkrétním čase není neměnný. Jednání je dle Starusse a Corbinové (1999) přizpůsobivé, plynulé a reagující. Mění se dle podmínek, za kterých se vyskytuje. Aspekty ovlivňující práci ŠSP se vyvíjí a mění v čase i intenzitě. Protektivní faktory lze cíleně ovlivňovat a pracovat na odolnosti jedince, na rozvoji zvládacích strategií i na osobnostním a profesním růstu. Strategie jednání ovlivňují také zkušenosti. Již jednou zvládnutá krize či náročná situace ovlivní další jednání v podobné situaci v budoucnosti.

Některé z respondentek nepovažují v aktuálním čase za důležité pracovat na svém osobnostním rozvoji, bud' z nedostatku časových možností, nebo proto, že považují současný stav za dostačující. Jiné informantky na svém 
profesním i osobnostním rozvoji pracují, a to bud' samy svépomocí, nebo prostřednictvím školitelů, kurzů a seminářů na odborné nebo i čistě spirituální úrovni.

Změny v aspektech ovlivňujících výkon profese však mohou přijít i úplně z vnějšku v podobě společenských či legislativních změn. Obecně lze říci, že k zásadním obecným společenským změnám však dochází relativně pomalu, vyžadují však většinou výraznější reakci a úpravu strategií jednání.

V našem případě se jedná především o komunikaci a jednání, o snahu být za každé situace stabilní a diplomatický. Některé jevy nelze pojmout jako sled postupných a uspořádaných fází či stadií, přesto v nich lze spatřit proces. Cílem diplomatického jednání, které vychází z požadavku na osobu školního speciálního pedagoga a které vede k odpovídající úrovni spolupráce, a tím k ovlivňování vzdělávacího procesu, je v jeho podstatě stabilizace a udržení nebo také zamezení negativnímu průběhu. I denní rutina a zaběhlé činnosti jsou každý den i každou hodinu ovlivňovány více či méně drobnými událostmi, které jsou převážně nepředvídatelné. Stabilizace jednání ve snaze udržet kvalitu a konstruktivnost ve stále se měnících podmínkách je nesmírně náročná a vyžaduje neustálé přizpůsobování se a cílenou práci na sobě samém. Toto přizpůsobování se a reagování na změny v podmínkách vnáší do zvládání proces (Strauss, Corbinová, 1999).

Tab. 9 Vlastnosti a dimenze procesů směřujících k zakotvené teorii

\begin{tabular}{|c|c|}
\hline Vlastnosti & Dimenze \\
\hline Rychlost změn & Velmi malá - malá - průměrná - velká - velmi velká \\
\hline Výskyt & $\begin{array}{l}\text { Neplánovaný - spíše neplánovaný - } \\
\text { částečně plánovaný - plánovaný - striktně plánovaný }\end{array}$ \\
\hline Charakter & $\begin{array}{l}\text { Nahodilý - spíše nahodilý - částečně uspořádaný - } \\
\text { spíše uspořádaný - uspořádaný }\end{array}$ \\
\hline Rozsah účinků & $\begin{array}{l}\text { Velmi malý - spíše malý - průměrný - spíše široký - } \\
\text { velmi široký }\end{array}$ \\
\hline Schopnost řízení & $\begin{array}{l}\text { Velmi nízká - spíše nízká - částečná - spíše vysoká - } \\
\text { velmi vysoká }\end{array}$ \\
\hline
\end{tabular}

\section{Matice podmiňujících vlivů}

Matice podmiňujících vlivů podle Strausse a Corbinové (1999) je mocným analytickým nástrojem, který nám pomáhá zachytit mnoho podmiňujících vlivů a následků, které se na jev vážou. Jednotlivé úrovně matice jsou různě významné pro daný jev a mají různý vliv na jednání nebo interakce. Jednotlivé úrovně mají mezi sebou určitý vztah a vzájemně se ovlivňují (viz obrázek 5). 


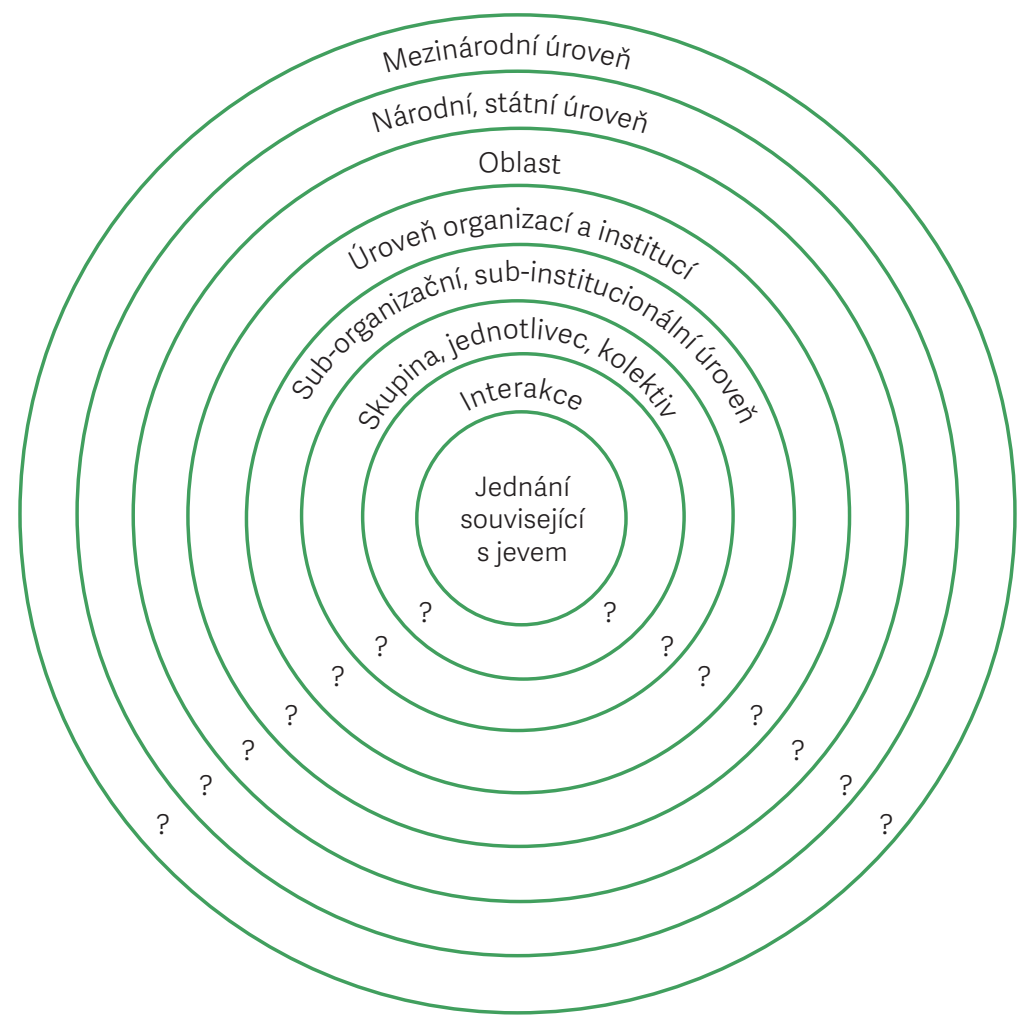

Obr. 5 Matice podmiňujících vlivů (Strauss \& Corbinová, 1999, s. 121)

Diplomatické jednání a úspěšné využívání komunikačních dovedností školním speciálním pedagogem je ve středu této matice. Pole interakce se týká všech, kdo se účastní jednání. ŠSP může jednat se žákem, s kolegou učitelem, $s$ vedením školy, s poradnou nebo s rodičem atp. Tato interakce probíhá s jasným cílem, a tím je pozitivní ovlivnění vzdělávání žáka nebo žáků. Interakce probíhá přímo, tedy z očí do očí, mezi ŠSP a konkrétní osobou nebo i více osobami (tým školního poradenského pracoviště, ředitel a zástupce ředitele školy, matka a otec dítěte atp.). Mưže také probíhat telefonickým kontaktem či písemně. Způsob a průběh interakce ovlivňuje mnoho podmínek, např́klad prostředí, ve kterém se odehrává. Zda je klidné a př́ijemné, či nikoliv. Svou roli hraje také čas, který je na jednání vymezen. Spěchá školní speciální pedagog, protože mu za dvacet minut začíná hodina speciálněpedagogické péče? Spěchá rodič dítěte do druhého zaměstnání? Mají zúčastnění na své jednání času tolik, kolik budou potřebovat? Dostatek času a klidné př́ijemné prostředí je pro kvalitní a úspěšnou interakci důležité. Ovlivňuje jak průběh, tak výsledek jednání i ochotu ke spolupráci. Svou roli hraje také motivace k setkání a jednání. Je rodič ve škole jen proto, že musí, protože byl pozván, 
nebo má upřímnou snahu pomoci svému dítěti k lepším výsledkům? Jedná ŠSP s poradenským zařízením jen proto, že je to nutná rutina, nebo opravdu touží po kvalitní spolupráci a očekává pomoc od poradenského zařízení?

Interakce jsou také ovlivněny širším okruhem podmínek, jako je např́iklad pohlaví, společenský status nebo víra. Bude školní speciální pedagog jednat jinak s matkou a jinak s otcem dítěte? Ovlivní způsob komunikace vyznání účastníků interakce? Tyto aspekty by neměly hrát velkou roli při interakcích. Nicméně někdy je potřeba se jim přizpůsobit. Jinou strategii zvolí školní speciální pedagog např́klad u rodičů romského žáka, kde je mnohdy patrná jiná hodnotová hierarchie než u rodičů z majority. Stejně tak zvolí jiný způsob komunikace u rodičů cizinců, kde se může odrážet odlišné kulturní prostředí.

Úroveň organizace je ovlivňována jak zespodu matice, tak z jejích vrchních polí. Za sub-organizační úroveň můžeme považovat školní poradenské pracoviště, jež má také vliv na fungování a práci školního speciálního pedagoga. Jednak tím, jací lidé ve smyslu jejich osobnostních charakteristik zde pracují, a dále také, a to především, jaké pozice jsou zajištěny v rámci ŠPP. Jedná se pouze o základní model poradenského pracoviště, nebo na škole působí rozšířený model, který navíc čítá vícero specialistů z každého oboru? Spolupracují zde dva školní speciální pedagogové? Dělají všichni všechno, nebo mají jasně rozdělené kompetence? Mají pravidelné porady a povědomí o činnosti toho druhého nebo o činnosti zbylých odborníků ŠPP? Obecně lze říci, že je výhodnější jasná struktura a rozdělení kompetencí a že všichni respondenti hodnotili za velmi výhodné, pakliže na škole působí celý rozšǐrený model poradenského pracoviště. Povinnosti se pak rozdělí do zvládnutelných celků mezi více osob zejména podle kompetencí. Mnoho informantek udávalo, že se necítí být kompetentní v jednání, které již hraničí s psychoterapeutickým rozhovorem. Stejně tak se některé respondentky necítí být kompetentní k práci s klimatem žákovského kolektivu a tuto práci přenechávají školním psychologům. Pro kulturní život školy by se jevil výborným specialistou sociální pedagog, který není respondentkami jmenovaný, nicméně jeho přítomnost na školách bývá čím dál žádanější a jeho pole působnosti je velmi široké, avšak ještě více neukotvené než v případě školního speciálního pedagoga.

Organizace, v tomto případě škola, ovlivňuje mnohé. Škola jakožto instituce se svými jednotlivými členy již předem nastavila určitý standard jednání a interakcí - jak ve směru k žákům, tak ve směru k jejich rodičům, ale i k veřejnosti. Jsou školy, které jsou velmi uzavřené a jejichž orientace je velmi výkonová a není zde př́lišný prostor pro partnerský dialog. Jsou školy velmi otevřené a partnerské ve směru jak k žákům, tak k rodičům, ale i ve smyslu spolupráce s vnějšími organizacemi. Škola často určuje hodnotový systém a styl jednání, který se odráží i v práci a nastavení školního speciálního pedagoga. Je také zásadní, jak dlouho je konkrétní ŠSP ve své pozici. Pokud jen krátce, teprve si nastavuje své vztahy a způsoby jednání a může být částečně hendikepován způsobem výkonu práce svého předchůdce. Nebo naopak, jeho předchůdce i samotná škola připravili dobrou půdu pro práci nováčka. 
Také spolupráce s jednotlivými kolegy je ovlivněna celkovou atmosférou školy, ale i názory a hodnotovým systémem konkrétních členů organizace. V tomto případě by mohl mít problémy mladý a začínající školní speciální pedagog, který se může (ale také vůbec nemusí) potýkat s despektem od starších kolegů učitelů či s jejich nesouhlasem s inkluzivními tendencemi společnosti, a tedy s neochotnou se na nich aktivně podílet. Organizaci (tedy školu) ovlivňují dále ekonomické a politické faktory, jako např́klad rozpočet školy, schopnost školy získat další finance, politické aspekty, kterým se škola musí podřídit, nebo společenské tendence a legislativní rámec řídící činnost a fungování škol a vzdělávacího procesu.

Škola by měla jednoznačně kooperovat s dalšími organizacemi. Svou činnost může škola směřovat vzhledem ke kulturnímu a lokálnímu umístění školy a ke své činnosti může využívat činnost dalších odborníků v dané oblasti. Př́kladem může být umístění školy v rizikové oblasti potýkající se s drogovou závislostí mladistvých. Tato skutečnost bude ovlivňovat zejména zaměření školního metodika prevence, ale i činnost ŠSP, který s metodikem často spolupracuje a může se podílet na vývoji preventivních opatření i na konkrétních preventivních činnostech. Mưže mít ve svých kompetencích práci s žáky s poruchami chování. I tato problematika spadá do speciální pedagogiky a záleží na škole, jak tyto kompetence rozloží mezi své pracovníky. Také jednání s rodiči, kteří se například s nějakým typem závislostního chování potýkají, musí podléhat určité změně strategie a nelze na takové rodiče uplatnit stejný přístup jako k bezproblémovým rodičům. Problém rodičů se bude dále odrážet v chování a školních výsledcích žáka, s čímž je také nutno odborně pracovat.

Z oblastní úrovně se můžeme přesunout na úroveň státní. Zde se jedná především o politické nastavení země, legislativní rámec definující práci škol a jejich jednotlivých zaměstnanců. Toto je problematika v otázce školních speciálních pedagogů, protože jejich činnost není stále plně ukotvena. Vzniká tady mnoho otazníků a nejasností jednak v rámci působnosti ŠSP, jednak například nejistoty v jeho financování, což se odráží na úrovni konkrétních jedinců. Ta působí velmi stresově a stres sám osobě, at' je jeho zdroj jakýkoliv, ovlivňuje výkon jedince. Pokud je školní speciální pedagog pod tlakem, at už z nejistoty o další financování jeho pozice, a tím o prodloužení pracovní smlouvy, nebo z důvodu př́liš mnoha povinností, které není jedinec schopen zvládnout, může chybovat ve volbě strategie jednání a komunikace může být neúspěšná. Člověk, který je ve stresu, může být více unaven, může být roztržitý či podrážděný a může reagovat jinak, než by reagoval, pokud by ve stresu nebyl.

Jedince na pozici ŠSP tedy ovlivňují i faktory na státní úrovni, jako jsou ekonomické a politické faktory, legislativa dané země nebo obecné společenské tendence a směr, kterým se školství konkrétní země ubírá. Velký vliv má například otevřenost země vůči okolnímu světu a novinkám, které často přicházejí 
právě z okolních zemí. Tímto se přesouváme na nadnárodní úroveň, která také ovlivňuje jednání školního speciálního pedagoga.

V naší oblasti působí značným vlivem EU, která řídí a koordinuje základní směr členských zemí, ovlivňuje jejich legislativu a spolupráci. Př́kladem mohou být integrační a inkluzivní snahy, které k nám přicházejí z okolních zemí, za vzorové lze považovat například země skandinávské, jejichž model je přebírán mnohými dalšími zeměmi a Česká republika na tyto tendence také reaguje. Díky integraci žáků se speciálními vzdělávacími potřebami do běžného typu škol došlo k potřebě mít ve školách speciálního pedagoga - kompetentního odborníka s určitými osobnostními předpoklady. Měl by být přesvědčen o tom, že lze za určitých podmínek pracovat i s dětmi se SVP v běžné škole a že i tam může dítě prospívat a být spokojené a že je to prospěšné nejen pro dané dítě, ale i pro společnost. Měl by být otevřený změnám a být schopen hledat nové cesty. Jeho úkolem je pak koordinovat činnosti všech zúčastněných tak, aby byly zmíněné podmínky co nejideálnější a průběh integrace hladký a bezproblémový, aby se na něm chtěli všichni podílet a snažili se o jeho co nejlepší výsledky. Ne vždy je tento úkol snadný, a proto musí být ŠSP zdatným diplomatem.

\subsection{Specifika profese školního speciálního pedagoga - shrnutí výsledků výzkumu}

Výzkum, z něhož vychází tato publikace, byl zaměřen na zmapování specifik profese školního speciálního pedagoga, s čímž korespondovala i hlavní výzkumná otázka. Ta byla dále precizována do několika dalších sledovaných podoblastí v rámci dílčích otázek, které se zaměřovaly na zjištění náplně práce ŠSP, jeho pracovní zátěž a její zvládání, limity profese, profesní role a postavení ŠSP mezi pedagogy i podíl školního speciálního pedagoga na životě školy.

Nalezení odpovědí nebylo vůbec snadné. Odpovědi na dílčí výzkumné otázky byly mnohdy naznačeny už ve fázi otevřeného kódování. K otázce náplně práce školního speciálního pedagoga se podrobně vyjadřujeme v kategorii i Agenda a denní rutina školního speciálního pedagoga, která zachycuje celkovou oblast působení školních speciálních pedagogů i s jemnými nuancemi, které jsou dány konkrétní školou či konkrétními jedinci vykonávajícími danou profesi. Pracovní zátěž a její zvládání pak podchycuje především kategorie 4 příznačně nazvaná Stres v profesi ŠSP aneb jeho příčiny, projevy a strategie zvládání, detailně popisuje zdroje stresu pramenící z profese ŠSP, jak se pracovní zátěž projevuje u konkrétních osob a jak ovlivňuje jejich činnost. Limity profese se promítají do mnoha kategorií, může jimi být např́klad omezující legislativní rámec nebo nejisté financování profese, které je jedním ze zdrojů stresu zejména pro matky samoživitelky, ale samozřejmě i pro ostatní. Málokomu je pravděpodobně příjemné žít a pracovat za okolností, 
kdy neví, jak dlouho budou finance na jeho pozici a zda bude i v následujících letech žádaná. Limity jsou samozřejmě také v osobách jedinců vykonávajících danou profesi - jejich osobnostní charakteristiky, věk, rodinné zázemí a zkušenosti. Omezení respondentky pocitují také v podmínkách, které české školství poskytuje pro výkon činnosti. Respondentka 6 konkrétně zmiňuje průběh procesu integrace v naší zemi a srovnává se zahraničními zkušenostmi. Podíl na životě školy je také patrný v některých kategoriích. Při pročtení kategorie I Agenda a denní rutina školního speciálního pedagoga zjistíme, že na kulturním životě školy se ŠSP nijak zásadně nepodílejí, není to jejich typickou náplní práce. Jejich účast na životě školy se ale promítá v podobě přímé činnosti s žáky v podobě např́klad pedagogické intervence či předmětů speciálněpedagogické péče, konzultacemi s žáky a řadovými pedagogy a spoluprací s dalšími členy školního poradenského pracoviště. Míra osobní angažovanosti na dalších akcích školy je pak dána osobnostním nastavením daného jedince i celkovým klimatem a filozofí školy.

Pokud bychom se tedy zaměřili na zodpovězení hlavní výzkumné otázky Jaká jsou specifika práce školního speciálního pedagoga?, již v prvních fázích analýzy vyvstala témata, která mají významný vliv na profesi ŠSP. Během analýzy se však kauzální vztahy a významy vyvíjely a měnily.

Z procesu otevřeného kódování bylo patrné, že práce školního speciálního pedagoga je specifická v oblasti spolupráce, a to tím, že v rámci výkonu této profese je člověk nucen spolupracovat s velkým množstvím lidí, institucí či organizací. Vliv na tuto činnost mají také škola, ve které působí konkrétní ŠSP, ale také celé společenství, které udává hlavní směr školství. Nejvýrazněji však rezonovalo téma osobnostních charakteristik a diplomatických dovedností ŠSP.

Axiální kódování pak ukázalo, že nejvýznamnějším specifikem je spolupráce v rámci činností školního speciálního pedagoga, a právě axiální kódování ukázalo vztahy mezi jednotlivými aspekty profese, z nichž se právě spolupráce jevila jako ústřední jev.

V poslední fázi selektivního kódování z ověřených metodologických postupů vzešlo, že ústředním jevem zkoumaného tématu je profesní role školního speciálního pedagoga, vnímaná jak subjektivně, tak očekáváními a požadavky externími. Profesní role odráží tedy očekávané standardy chování a jednání i náplň práce a kvalitu jejího provedení. Z rozhovorů vyplynulo, že subjektivní očekávání od profese je sdružovat, spojovat, vytvářet mosty, a to vzhledem k zájmům dětí. Velkým problémem by v tomto směru byly tendence ke konfliktnímu jednání. Na ŠSP jsou kladeny požadavky nejen vysokého standardu odborných kompetencí a jejich rozšiřování, ale také požadavky na osobnostní kvality. Role, tedy to, co je od nás očekáváno, reguluje naše chování v těchto pozicích. Většinou se snažíme naplňovat daná očekávání a jednat tak, aby naše počínání mělo bezproblémový průběh a pozitivní výsledky. Role a počínání v nich jsou ovlivněny také našimi názory, postoji 
a hodnotami (Nakonečný, 1997; Jandourek, 2001; Matoušek, 2008; Výrost \& Slaměník, 2008; Špirudová, 2015).

Významný vliv na ústřední jev mají podmínky, za kterých je profese vykonávána. Jedná se o kontext společnosti a dohodu mezi ŠSP a školou, filozofii školy, stres, jeho protektivní faktory a rizikové faktory, způsoby jeho zvládání, osobnostní charakteristiky ŠSP i interakce, které v rámci své činnosti podstupuje. Interakcí je v profesi ŠSP mnoho a spolu s nimi přechází i do určitých dílčích rolí. Jimi jsou například role poradce a konzultanta či manažera, koordinátora, vedoucího pracovníka nebo podřízeného, je také odborníkem nebo kolegou, administrativním pracovníkem a zprostředkovatelem služeb. Do profesní role se mohou promítat i jiné role, např́klad role partnera a rodiče či kamaráda. Hranice mezi rolemi by měly být evidentní a je potřeba je udržovat. Zároveň je potřeba, aby uměl ŠSP mezi rolemi flexibilně přecházet a upravovat své styly jednání vzhledem k aktuální situaci a typu interakce.

Detailně jsou tyto vztahy popsány v kapitole 5.2.3 Profesní role školního speciálního pedagoga (selektivní kódování), zejména v kostře příběhu, která se zabývá právě vztahy mezi ústředním jevem a dalšími podmínkami. Tyto vztahy jsou také naznačeny v paradigmatickém schématu selektivního kódování. Dále o těchto vztazích pojednává kapitola Proces aneb od jevu ke strategiím a následně jsou podrobněji specifikovány v kapitole Matice podmiňujících vlivů.

Zmíněné kapitoly pojednávají o profesní roli školního speciálního pedagoga, jejímž specifikem je zejména potřeba komunikační dovednosti a schopnosti diplomatického jednání. Popsány jsou také důsledky počínání školního speciálního pedagoga. Kapitoly dále detailně popisují vliv těchto schopností nejen na konkrétní činnosti, ale také na širší kontext, dále pak popisují podmínky, které tyto schopnosti formují a ovlivňují pozitivním či negativním způsobem. Zmiňují i možnosti, jak bojovat proti negativním vlivům, jímž jsou např́klad stres nebo riziko syndromu vyhoření. Stres lze obecně považovat za spíše negativní, ačkoliv respondentka 1 uvádí, že stres ji může i nabudit k lepším výkonům. Dalšími vlivy jsou škola a společnost a osobnostní charakteristiky konkrétního ŠSP.

Profesionální úroveň interakcí vedoucích ke konstruktivní spolupráci vyžaduje od profesionála vysokou míru komunikačních schopností a vyjednávacích dovedností. Kladně laděná spolupráce vyžaduje takt, diplomacii a flexibilitu ve vyjednávacích strategiích i jejich široký repertoár. Cílem využití těchto strategií by měl být vždy zájem dítěte, nikoliv narcistní dosažení vlastních požadavků a prosazení moci.

Spolupráce s lidmi a organizacemi je součástí práce ŠSP, proto jsou komunikační dovednosti a vhodné vyjednávací strategie nezbytností pro úspěšné vykonávání této profese. Diplomatické jednání by mělo být naprostým standardem pro výkon profese ŠSP. Volbou vhodných strategií jednání a diplomatickou komunikací mohou ŠSP ovlivnit mnohé, i když se to na první pohled nemusí zdát. ŠSP má možnost svou prací ovlivnit přístup pedagoga k žákovi 
a k jeho individuálním potřebám. Tím může ovlivnit postoj učitelů k inkluzi. Důsledkem může být i změna postoje veřejnosti k inkluzivním tendencím i k pedagogické profesi a ke škole jako instituci. V konečném důsledku může těmito na první pohled drobnými změnami na úrovni jednotlivců nepozorovaně ovlivnit úroveň vzdělávacího procesu v zemi.

\subsection{Závěrečné shrnutí}

Ve výpovědích respondentek se objevovala různá témata, která se často shodovala, ale objevovala se i témata ojedinělá, která byla zajímavá a dala by se využít v dalších výzkumech, ale pro potřeby této práce nebyla př́liš významná. Výzkumnou skupinou byli lidé, kteří mají osobní zkušenost s profesí školního speciálního pedagoga. Soubor nebyl př́liš limitován délkou praxe, podmínkou však byl alespoň rok praktických zkušeností s výkonem profese ŠSP. Vybraný soubor zahrnoval sedm žen. Získaná data byla podrobena analýze pomocí ověřených metodologických postupů. Byl zvolen kvalitativní výzkum a zakotvená teorie realizovaná s oporou odborné literatury, zejména autorů Strauss a Corbinová (1999) a Řiháček a Hytych (2013).

Kroky analýzy korespondují metodologickými publikacemi a každý z jednotlivých kroků přinášel nové výsledky a jiný pohled na specifika profese školního speciálního pedagoga. Jednotlivé kroky byly popsány, nicméně v realitě nejsou nikdy takto striktně odděleny, ale spíše se prolínají, což potvrzují i autoři využitých publikací.

Témata identifikovaná z rozhovorů s respondentkami korespondují také s teoretickými kapitolami. Výpověd' informantek o náplni jejich práce se nijak významně neliší od teoretických konceptů pojednávajících o profesi ŠSP. V teorii jsme se také dotkli inkluze a její podoby v jiných zemích. Toto téma taktéž rezonuje v sesbíraných datech a zdá se, že inkluze a její aktuální podoba je v naší zemi palčivým tématem obsahujícím mnoho názorů. Z rozhovorů však vyplývá, že školní speciální pedagogové nejsou s aktuálním průběhem inkluze příliš spokojení a mají mnoho výhrad. Z rozhovorů je také patrné, že mnoho škol disponuje rozšířeným modelem školního poradenského pracoviště a respondentky tento rozšířený model kvitují a považují spolupráci různých odborníků za velmi cennou a obohacující.

Přesto, že profese školního speciálního pedagoga není respondentkami považována za extrémně stresovou, i zde se vyskytují aspekty, které jsou pro respondentky zátěžové a každá z nich má své strategie zvládání, at' už jsou to strategie vědomě využívané a rozvíjené, nebo spíše užívané na intuitivní úrovni. Všechny respondentky se však shodují, že je nutné v tomto ohledu vyvíjet určitou aktivitu a dbát o své duševní zdraví stejně jako o to fyzické.

Výsledkem realizovaného výzkumu je klíčové zjištění, že zásadním specifikem profese je pojetí profesní role, která je podmíněna externími požadavky, společenským kontextem, konsenzem mezi konkrétním ŠSP a konkrétní 
školou. Důležitým aspektem je požadavek diplomatického jednání školního speciálního pedagoga. Schopnost ŠSP aplikovat vhodné komunikační strategie je ovlivněna mnoha faktory. Jsou to třeba potřeby školy, osobnostní charakteristiky jedince, vliv stresových faktorů na jedince, zvládání stresové zátěže, zkušenosti daného jedince jak se zátěžovými situacemi, tak zkušenosti profesní. To vše, a jistě by se našlo mnoho dalších podmiňujících faktorů, ovlivňuje aplikaci komunikativních dovedností a diplomatického vyjednávání s jednotlivci, organizacemi či institucemi. Úspěšná aplikace těchto dovedností a vysoká míra komunikační zdatnosti ovlivňuje kvalitu a konstruktivnost spolupráce a v širším kontextu může ovlivnit vzdělávací proces a společenské mínění. 


\section{Slovo závěrem}

Profese školního speciálního pedagoga je ve školách stále více a více žádaná a ve společnosti potřebná. Nevznikla sama od sebe nebo náhodou, vzešla z potřeb pedagogů a žáků díky inkluzivním snahám společnosti a podpoře rovného vzdělávání. Na pedagogy je kladeno stále více požadavkủ se škálou potřeb dětí se specifickými vzdělávacími potřebami, která je velmi široká, a není proto možné, aby vše dokázal pojmout a správně, efektivně řešit jeden jediný člověk, např́klad učitel. Tak jako medicína má své odborníky na určité oblasti, tak i školství potřebuje své specifické odborníky, kteří budou podporovat kvalitu výchovně-vzdělávacího procesu ve škole a rozvoj kompetencí žáků, budou oporou učitelům i rodičům dětí.

Požadavky na všechny odborníky, školního speciálního pedagoga nevyjímaje, jsou vždy vysoké a nadstandardní. Školní speciální pedagog musí disponovat nejen odpovídajícím vzděláním dle platné legislativy, ale také vysokými osobnostními kvalitami. Nutností je diplomatické nadání a dobrá schopnost komunikace a spolupráce. Kategorie schopnosti diplomatického jednání zahrnuje několik témat, jako jsou potřebné vlastnosti pro práci školního speciálního pedagoga, přístup k zaměstnání, role pracovníka a způsoby komunikace školního speciálního pedagoga. V rámci výkonu této profese je také nezbytné spolupracovat s velkým množstvím lidí a institucí či organizací. Vliv na danou činnost má i konkrétní škola, ale také celé společenství, které udává hlavní smĕr školství. Schopnost aplikace vhodných komunikačních strategií pak závisí nejen na osobních charakteristikách konkrétních pracovníků, ale také na mnoha dalších faktorech, jako jsou potřeby školy, vliv stresových faktorů a zkušenosti daného jedince. Úspěšná aplikace těchto dovedností a vysoká míra komunikační zdatnosti ovlivňuje kvalitu a konstruktivnost spolupráce a v širším kontextu mủže ovlivnit vzdělávací proces a společenské mínění.

Kniha se rovněž zaobírá pracovní zátěží a strategiemi jejího zvládání a způsoby psychohygieny. Stres, zátěž, protektivní a rizikové faktory a strategie aplikované konkrétními jedinci pro zvládnutí náročných situací jsou aspekty, které významně ovlivňují zmiňované diplomatické jednání, úroveň spolupráce a komunikace. Tento vztah je podrobně rozpracován v realizovaném výzkumu. 
Opomenout nelze etické aspekty profese, které provázejí pomáhající profese každodenní praxí. Někdy jsou zcela zřejmé a evidentní, jindy se pohybují na velmi tenké hraně správného rozhodnutí. Pro takové případy vznikají profesní kodexy, které formulují všeobecně platné normy a morální zásady, kterými by se měl odborník řídit a hledat v nich oporu, pokud se nalézá v nejasné situaci. Etické kodexy obsahují typ poskytovaných služeb a odrážejí respekt ke klientům. Popisují také profesionální normy a omezení z profese vyplývající, jako například poskytnutí pouze takových služeb, ke kterým je pracovník kompetentní. Školní speciální pedagogové prozatím nemají v ČR svůj ustanovený etický kodex, mohou však čerpat inspiraci z již existujících kodexů příbuzných profesí.

Potenciál publikace vidíme prostřednictvím jejího vydání v odhalení a popisu specifik profese školního speciálního pedagoga a reflexi zkušeností praktikujících odborníků v této profesi. Jedná se o odborníky s významným společenským posláním, pro jehož naplnění je nutné nejen odpovídající vzdělání, ale rovněž vnitřní motivace k dalšímu profesnímu rozvoji a ve velké míře také rozvoji osobnostnímu, protože osobnostní charakteristiky hrají významnou roli v kvalitě výkonu profese školního speciálního pedagoga. 


\section{Použitá literatura}

Asociace pracovníků SPC (2016). Etický kodex pracovníků SPC [online]. Dostupné z: http://www.apspc.cz/informace/eticky-kodex/eticky-kodex-poradenskychpracovniku-v-spc

Bartko, D. (1980). Moderní psychohygiena. Praha: Panorama.

Bartoňová, M., \& Vítková, M. (2019). Inkluzivní pedagogika. Opava: Slezská univerzita. Bedrnová, E. (1996). Duševní hygiena a sebeřízení. Praha: Vysoká škola ekonomická.

Booth, T., \& Ainscow, M. (2002). Index for Inclusion. Developing learning and partitipation in schools. London: Centre for Studies on Inclusive Education.

Boyle, G. J., \& Joss-Reid, J. M. (2004). Relationship of humour to health:

a psychometric investigation. British Journal of Health Psychology, 9(1), 51-66.

doi: 10.1348/135910704322778722

Brodie, J. D. (1982). Career-sustaining behaviors in psychotherapists: Interpersonal and intrapersonal support systems. Dissertation Abstracts International: Section B. Sciences and Engineering, 44, 2547-2548.

Buchtová, B. et al. (2002). Nezaměstnanost. Psychologický, ekonomický a sociální problém. Praha: Grada Publishing.

Buchwald, P. (2013). Stres ve škole a jak ho zvládnout. Brno: Edika.

Bundesministerium für Arbeit und Soziales. (2016). Nationaler Aktionsplan 2.0 [online]. Dostupné z: https://www.gemeinsam-einfach-machen.de/GEM/DE/AS/NAP/ NAP_20/nap_20_node.html

Bundesministerium für Bildung. (2016). Geschichte des österreichischen Schulwesens. Dostupné z: https://www.bmb.gv.at/schulen/bw/ueberblick/sw_oest.html

Bůžek, A. (2011). Století dítěte a práva dítěte. In Sdružení zastánců dětských práv ČR [online]. Dostupné z: http://dcicz.org/userfiles/file/sdpd.pdf

Cakirpaloglu, P., Šmahaj, J., Dobešová Cakirpaloglu S., \& Lemrová, S. (2015). Šikana, úzkost a deprese mezi zaměstnanci ve vybraných krajích ČR. In Řehulka, E. Škola a zdraví v 21. století (s. 34-43). Brno: Masarykova univerzita.

Carver, C. S., Scheier, M. F., \& Weintraub, J. K. (1989). Assessing coping strategies: a theoretically based aproach. Journal of Personality and Social Psychology, 56(2), 267-283 [online]. Dostupné z: https://www.ncbi.nlm.nih.gov/pubmed/2926629.

Cooper, C. D. (2005). Just Joking Around? Employee Humor Expression As An Ingratiatory Behavior. Academy of Management Review, 30(4), 765-776.

doi: 10.5465/amr.2005.18378877. 
Cooper, F. (2012). Professional Boundaries in Social Work and Social Care: a Practical Guide to Understanding, Maintaining and Managing Your Professional Boundaries. London: Jessica Kingsley Publishers.

Čedík, M. (2002). Etický kodex pracovníků středisek výchovné péče, návrh k odborné diskusi pro Asociaci SVP. Interní materiál.

Čech, T. (2007). Vize uplatnění sociálního pedagoga v procesu ozdravení školy. In Řehulka, E. et al. Škola a zdraví pro 21. století 2 (s. 50-57). Brno: Paido.

Čech, T. (2011a). Dítě v těžké životní situaci a jeho odborná opora v českých školách. In Lukšík, I.; Smetanová, D. (ed.) Deti v taažkých životných situáciách (s. 16-24). Bratislava: Univerzita Komenského. Ed. Sociálnopedagogické štúdie.

Čech, T. (2011b). Mobbing jako negativní fenomén v prostředí základních škol. Brno: Masarykova univerzita.

Čerstvá, L., \& Čech, T. (2009) Sociální pedagog a vize jeho uplatnění v základní škole. In Soják, P. (ed.) Symposium sociální pedagogiky na PdF MU 2 (s. 65-74). Brno: Masarykova univerzita.

Česká odborná společnost pro inkluzivní vzdělávání. (2019). Index inkluze aneb Průvodce rozvoje školy [online]. Dostupné z: https://cosiv.cz/cs/2019/05/15/ index-inkluze-pruvodce-rozvoje-skoly-na-zaklade-inkluzivnich-hodnot/

Decker, W. H., \& Rotondo, D. M. (2001). Relationships Among Gender, Type Of Humor, And Perceived Leader Effectiveness. Journal of Managerial Issues, 13(4), 450-465. Dostupné z: https://psycnet.apa.org/record/2001-09832-003.

Dobešová Cakirpaloglu, S., \& Čech, T. (2019) The Effect of Coping Strategies on Workplace Bullying in High School Teachers. In ICLEL 2019 Conference Proceedings Book (s. 620-628). Baku: Sakarya University.

Docking, J. (1990). Primary School and Parents: Rights, Responsibilities and Relationship. London: Hodder\&Stoughton.

Drotárová, E., \& Drotárová, L. (2003). Relaxační metody: Malá encyklopedie. Praha: Epocha.

Ďurič, L. (1969). Výkonnost a únava učitel'ov vo vyučovacom procese. Bratislava: SPN.

Dyson, A. (2010). Entwicklung inklusiver Schulen. Drei Perspektiven aus England. Die deutsche Schule, 102(2), 115-129. Dostupné z: https://www.ganztagsschulen.org/ _downloads/Beitrag_Dyson_aus_DDS_2_2010.pdf.

European Agency for Development in Special Needs Education. (2003). Special Needs Education in Europe. Odense: European Agency for Development in Special Needs Education.

European Agency for Development in Special Needs Education. (2011). Participation in Inclusive Education - A Framework for Developing Indicators. Odense: European Agency for Development in Special Needs Education.

Feyerer, E. (2015). Inklusive Lehrer_Innenbildnug. Österreich geht neue Wege. Gemeinsam leben. Zeitschrift für Inklusion, 21(1), 3-18.

Folkman, S., \& Lazarus, R. S. (1980). An Analysis of Coping in a Middle-Aged Community Sample. Journal of Health and Social Behavior, 21(3), 219.

Dostupné z: https://psycnet.apa.org/record/1981-23416-001. 
Folkman, S., \& Lazarus, R. S. (1988). Ways of Coping Questionnaire. PsycTESTS Dataset. doi: 10.1037/t06501-000.

Fontana, D. (2016). Stres v práci a v životě, jak ho pochopit a zvládat. Praha: Portál.

Foucault, M. (1994). Dějiny šílenství. Praha: Nakladatelství Lidové noviny.

Gelkopf, M., \& Kreitler, S. (1996). Is Humor only fun, an alternative cure or magic? The Cognitive Therapeutic Potential od Humor. Journal of Cognitive Psychotherapy: An International Quarterly, 10, 235-254. Dostupné z: https://connect.springerpub.com/ content/sgrjcp/10/4/235

Giddens, A. (1999). Sociologie. Praha: Nakladatelství Argo.

Greger, D., Chvál, M., Walterová, E., \& Černý, K. (2009). Názory českých rodičů a veřejnosti na časné rozdělování žáků. Orbis scholae, 3(3), 51-78.

Grofová, K., \& Černý, V. (2015). Relaxační techniky pro tělo, dech a mysl: návrat k přirozenému uvolnění. Brno: Edika.

Halík, T. (1993). Sedm úvah o službě nemocným a trpícím. Brno: Cesta.

Haškovcová, H. (2006). Etické kodexy - záchrana, past nebo módní formalita? In Kružík, J. (Ed.). Vita activa. Vita contemplativa. Janu Sokolovi k sedmdesátým narozeninám (s. 328-334). Praha: Univerzita Karlova.

Hormandlová, T. (2020). Profesní obraz školního speciálního pedagoga v podmínkách základní školy (diplomová práce). Brno: Masarykova univerzita, Pedagogická fakulta. Vedoucí práce: Tomáš Čech.

Iatridou, E. (2016). Teaching assistant role in a school in Sweeden: An ethnographic case study (diplomová práce). Gothenburg: University of Gothenburg, Faculty of Education. Vedoucí práce: Susanne Garvis.

Ingstrup, M. S., Mosewich, A. D., \& Holt, N. L. (2017). The Development of Self-Compassion Among Women Varsity Athletes. The Sport Psychologist, 31(4), 317-331. doi: 10.1123/tsp.2016-0147.

Institut pedagogicko-psychologického poradenství (nedat.) Inovace koncepce poradenských služeb ve škole [online]. Dostupné z: http://www.ippp.cz/rspp/images/ vystupy/inovovan.pdf

Jandourek, J. (2001). Sociologický slovník. Praha: Portál.

Jankovský, J. (2003). Etika pro pomáhající profese. Praha: Triton.

Janků, K. (2013). Kapitoly z integrativní speciální pedagogiky. Ostrava: Ostravská univerzita.

Jennessen, S., et al. (2010). Leben mit Körperbehinderung. Perspektiven der Inklusion. Stuttgart: Verlag W. Kohlhammer.

Jesenský, J. (2000). Základy komprehenzivní speciální pedagogiky. Hradec Králové: Gaudeamus.

Jílek, D. (2013). Cesty ke škole respektující a naplňující práva dítěte. Boskovice: Českobritská o.p.s.

Jirásko, J. (2018). Polemika: Je české školství rigidní, svazují ho tradiční přístupy? In Učitelské listy [online]. Dostupné z: http://www.ucitelske-listy.cz/2018/10/polemika-jeceske-skolstvi-rigidni.html 
Josefsson, Ch. (2002). Utredning om Barn/Elever i behov av särskilt stöd i förskola, grundskola och särskola. Schweden: Boras Stad.

Kasíková, H. (2007). Pedagogika pro učitele. Praha: Grada.

Kasíková, H., \& Straková, J. (ed.). (2011). Diverzita a diferenciace v základním vzdělávání. Praha: Karolinum.

Keller, J. (2005). Úvod do sociologie. Praha: Slon.

Knotová, D. et al. (2014). Školní poradenství. Praha: Grada.

Kommunal. (nedat.) Lärarassistent [online]. Dostupné z: https://www.kommunal.se/ yrke/lararassistent

Kopřiva, K. (2013). Lidský vztah jako součást profese. Praha: Portál.

Kovářová, R., \& Vitásková-Janků, K. (2008). Postavení a kompetence speciálního pedagoga v rámci integračního procesu na běžné škole. Ostrava: Ostravská univerzita.

Kratochvílová, J. (2013). Kvalita inkluzivní školy: její hodnotová dimenze a podmínky (habilitační práce). Brno: Masarykova univerzita, Pedagogická fakulta [online]. Dostupné z: https://is.muni.cz/do/rect/habilitace/1441/Kratochvilova/habilitace/ Kratochvilova_habilitace_nahled.pdf

Křivohlavý, J. (1993). Povídej, naslouchám. Praha: Návrat.

Křivohlavý, J. (1994). Jak zvládat stres. Praha: Grada, Avicentrum.

Křivohlavý, J. (2001). Psychologie zdraví. Praha: Portál.

Křivohlavý, J. (2012). Hořet, ale nevyhořet. Kostelní Vydří: Karmelitánské nakladatelství.

Kucharská, A. et al. (2013). Školní speciální pedagog. Praha: Portál.

Kucharská, A., \& Toman, J. (2010). Komparace projektového záměru RŠPP-VIP II a aktuálního stavu ŠPP. Interní metodická zpráva č. 1. Praha: IPPP ČR.

Kucharská, A., Mrázková J. et al. (2014). Metodika práce školního speciálního pedagoga zapojeného ve školí poradenském pracovišti. Praha: NÚV.

Lazarová, B. et al. (2015). Řízení inkluze ve škole. Brno: Masarykova univerzita.

Lazarus, R. S. (1966). Psychological stress and coping precess. New York: McGraw-Hill.

Lazarus, R. S. (1993). From psychological stress to emotion: a history of changing outlooks. Annual Review of Psychology, 44, 1-21.

Lazarus, R. S. (1994). Psychological stress in the workplace. In Parewé, P. L., \& Cranall, R. (Eds.), Occupational stress: a handbook (s. 3-14). Washington. D. C.: Taylor \&Francis.

Lechta, V. et al. (2010). Základy inkluzivní pedagogiky. Praha: Portál.

Lemrová S., \& Dobešová Cakirpaloglu S. (2016). Potřeby, hodnoty a postoje českých učitelů v souvislosti s jejich profesí. In Maierová E., Viktorová L., \& Dolejš M. (Eds.) PhD existence 2016 (s. 160-166). Olomouc: Univerzita Palackého v Olomouci.

Lišková, K. (2015). Profesionální pomoc je velmi složitá záležitost. Sociální práce, 15 [online]. Dostupné z: http://www.socialniprace.cz/zpravy.php?oblast=1\&clanek=824

Lovaš, L. et al. (2011). Osobné a situačné kontexty sebekontroly. Košice: UPJŠ. 
Márová, I., Pančocha, K., \& Přinosilová, D. (2015). Syndrom vyhoření u pedagogických pracovníků základních škol speciálních [online]. Speciální pedagogika, 25(2). Dostupné z: http://dspace.specpeda.cz/handle/o/1563

Matějček, Z. (1992). Dítě a rodina v psychologickém poradenství. Praha: Státní pedagogické nakladatelství.

Matoušek, O. (2008). Slovník sociální práce. Praha: Portál.

Mertin, V. et al. (2013). Výchovné poradenství. Praha: Wolters Kluwer.

Míček, L. (1984). Duševní hygiena. Praha: Státní pedagogické nakladatelství.

Michalík, J. (2001). Obecné podmínky školské integrace v České republice.

In Müller, O. et al. Dítě se speciálními vzdělávacími potřebami v běžné škole (s. 10-52).

Olomouc: Univerzita Palackého v Olomouci.

Michalík, J. (2003). Proces transformace ve speciální pedagogice. In Renotierová, M. Základy speciální pedagogiky. Olomouc: Univerzita Palackého.

Michalík, J., Baslerová, P., \& Felcmanová, L. (2015). Katalog podpůrných opatření pro žáky s potřebou podpory ve vzdělávání z důvodu zdravotního nebo sociálního znevýhodnění: obecná část. Olomouc: Univerzita Palackého v Olomouci.

Ministerstvo školství, mládeže a tělovýchovy ČR. (2014). Strategie vzdělávací politiky České republiky do roku 2020 [online]. Dostupné z: http://www.vzdelavani2020.cz/ images_obsah/dokumenty/strategie-2020_web.pdf

Ministerstvo školství, mládeže a tělovýchovy ČR. (2002). Národní program rozvoje vzdělávání v České republice. Bílá kniha. [online]. Dostupné z:

http://www.msmt.cz/dokumenty/bila-kniha-narodni-program-rozvoje-vzdelavaniv-ceske-republice-formuje-vladni-strategii-v-oblasti-vzdelavani-strategie-odrazicelospolecenske-zajmy-a-dava-konkretni-podnety-k-praci-skol

Ministerstvo školství, mládeže a tělovýchovy ČR. (2005). Koncepce poradenských služeb ve škole. [online]. Dostupné z: http://www.msmt.cz/file/38107_1_1

Ministerstvo školství, mládeže a tělovýchovy ČR. (2010). Národní akční plán inkluzivního vzdělávání [online]. Dostupné z: https://www.databaze-strategie.cz/cz/ MSMT/strategie/narodni-akcni-plan-inkluzivniho-vzdelavani-2010-2013

Ministerstvo školství, mládeže a tělovýchovy ČR. (2015). Etický rámec výzkumu [online]. Dostupné z: https://www.msmt.cz/file/35780?highlightWords=etika+vyzkumu

Ministerstvo školství, mládeže a tělovýchovy ČR. (2019). Akční plán inkluzivního vzdělávání na období 2019-2020 [online]. Dostupné z: http://www.msmt.cz/file/49950

Miovský, M. (2006). Kvalitativní př́stup a metody v psychologickém výzkumu. Praha: Grada

Mrázková, J. (2007). Sonda do profese školního speciálního pedagoga. Zpravodaj Pedagogicko-psychologické poradenství, 50, 35-44.

Mrázková, J. (2008). Profese školního speciálního pedagoga. Praha: IPPP ČR.

Mühlpachr, P. (2001). Vývoj ústavní péče. Filosoficko-historický pohled. Brno: Masarykova univerzita.

Musil, L. (2004). „Ráda bych Vám pomohla, ale“: dilemata práce s klienty v organizacích. Brno: Marek Zeman.

Nakonečný, M. (1997). Encyklopedie obecné psychologie. Praha: Academia. 
Nedělníková, D. (2008). Etická dilemata v terénní sociální práci. In Janoušková, K., \& Nedělníková, D. (Eds.). Profesní dovednosti terénních pracovníků: sborník studijních textů. (s. 377-390). Ostrava: Ostravská Univerzita.

Novosad, L. (2009). Poradenství pro osoby se zdravotním a sociálním znevýhodněním: základy a předpoklady dobré poradenské praxe. Praha: Portál.

Oakland, T., Goldmanová, S., \& Bishoff, H. (1994). Etické normy práce školního psychologa (normy International School Psychology Association přijaté Asociací školní psychologie SR a ČR na 3. sjezdu v roce 1994). Asociace školní psychologie SR a ČR [online]. Dostupné z: https://docplayer.cz/1312500-Eticke-normy-prace-skolniho-psychologa.html

Pančocha, K., \& Slepičková, L. (2012). Postoje k osobám s postižením u obecné populace ČR. Attitudes of general public towards people with disabilities in the Czech Republic. In Bartoňová, M., \& Vítková, M. et al. Vzdělávání žáků se speciálními vzdělávacími potrebami VI. Education of Pupils with Special Educational Needs VI (s. 41-50). Brno: Masarykova univerzita.

Paulík, K. (2012). Psychologické aspekty zvládání zátěže muži a ženami. Ostrava: Ostravská univerzita.

Paulík, K. (2017). Psychologie lidské odolnosti. Praha: Grada Publishing.

Pešatová, I., \& Matulayová, T. (2013). Kompetence školních speciálních pedagogů a školních sociálních pracovníků v inkluzivním školství v České republice. Liberec: Technická univerzita v Liberci.

Pešatová, I., \& Tomická, V. (2007). Úvod do integrativní speciální pedagogiky. Liberec: Technická univerzita v Liberci.

Peterková, M. (2014). Kurz duševní rovnováhy: zbavte se stresu, napětí a úzkosti. Praha: Portál.

Pilař, J. (2010). Žáci se speciálními vzdělávacími potřebami - Vliv zahraničních trendů na náš vzdělávací systém. In Metodický portál rvp.cz [online]. Dostupné z: http://clanky.rvp.cz/clanek/c/S/10161/zaci-sespecialnimi-vzdelavacimi-potrebami-vlivzahranicnich-trendu-na-nas-vzdelavacisystem.html/

Průcha, J. (1995). Výzkum učitelské profese. Alfa revue, 5(2), 5-14.

Průcha, J., \& Kansanen, P. (2015). Školní vzdělávání ve Finsku. Praha: Karolinum.

Průcha, J., \& Švaříček, R. (2009). Etický kodex české pedagogické vědy a výzkumu. Pedagogická orientace, 19(2), 89-105.

Ptáček, R., Bartůněk, P. et al. (2011). Etika a komunikace v medicíně. Praha: Grada.

Reamer, F. (2006). Social Work Values and Ethics. New York: Columbia University Press.

Reiter, N. (2007). Work Life Balance: What DO You Mean? The Ethical Ideology Underpinning Appropriate Application. The Journal of Applied Behavioral Science, 43(2), 273-294. doi: 10.1177/0021886306295639.

Renotierová, M. (2005). Základy speciální pedagogiky. Olomouc: Univerzita Palackého. Resman, M. (2003). Integrácia/inklúzia medzi zámerom a uskutečnením. Psychológia a patopsychológia dietata, 38(2), 161-174.

Růžička, M., Pastieriková, L., Smolíková, M., Fialová, K., Baslerová P. et al. (2020). Speciální pedagog a další aktéři školního poradenského pracoviště ve společném vzdělávání. Olomouc: Univerzita Palackého v Olomouci. 
Řiháček, T., \& Hytych, R. (2013). Metoda zakotvené teorie. In Řiháček, T., Čermák, I., Hytych, R. et al. Kvalitativní analýza textů: čtyři př́stupy (s. 44-74). Brno: Masarykova univerzita.

Santiago, P., Gilmore, A., Nusche, D., \& Sammons, P. (2012). Zpráva OECD o hodnocení vzdělávání v České republice: závěry [online]. Dostupné z http://www.msmt.cz/file/20716

Schmidbauer, W. (2008). Syndrom pomocníka. Praha: Portál.

Skär, L., \& Tam, M. (2001). My assistant and I: Disabled children's and adolescents' roles and relationships to their assistants. Disability \& Society, 16(7), 917-931.

Skolverket. (2019). Statsbidrag för lärarassistenter [online]. Dostupné z: https://www.skolverket.se/skolutveckling/statsbidrag/statsbidrag-forlararassistenter-2019.

Slavíková, I. (2006). Etické aspekty v práci školního psychologa/speciálního pedagoga. Přednáška v rámci specializačního studia „Školní pedagogicko-psychologické služby“. Praha: Univerzita Karlova.

Slovenská komora učitelov (2017). Etický kódex učitel’a [online]. Dostupné z: https://sku.sk/dokumenty/eticky-kodex-ucitela/

Smékal, V. (2007). Pozvání do psychologie osobnosti: člověk v zrcadle vědomí a jednání. Brno: Barrister and Principal.

Soják, P., \& Čech, T. (2010). Cesta do školy aneb výzkum potřebnosti a uplatnitelnosti sociálního pedagoga ve škole. In Výzkum zaměřený na...: základní směry výzkumu Katedry sociální pedagogiky PdF MU (s. 109-119). Brno: Masarykova univerzita.

Sovák, M. (1953). O novém pojetí defektologie. In Ludvík, F. et al. Mládež vyžadující zvláštní péče. Praha: Státní pedagogické nakladatelství.

Společnost sociálních pracovníků ČR (2006). Etický kodex sociálních pracovníků ČR [online]. Dostupné z: http://sspcr.xf.cz/code.html.

Stevanovic, P., \& Rupert, P. A. (2004). Career-Sustaining Behaviors, Satisfactions, and Stresses of Professional Psychologists. Psychotherapy: Theory, Research, Practice, Training, 41(3), 301-309. doi: 10.1037/0033-3204.41.3.301.

Stock, Ch. (2010). Syndrom vyhoření a jak jej zvládnout. Praha: Grada Publishing.

Straková, J. (2009). Vzdělávací politika a mezinárodní výzkumy výsledků vzdělávání v ČR. Orbis Scholae, 3(3), 103-118.

Straková, J., Simonová, P., \& Polechová, P. (2011). Overcoming school failure: Background report for the Czech Republic. Praha: Ústav pro informace ve vzdělávání.

Strauss, A. L., \& Corbin, J. (1999). Základy kvalitativního výzkumu. Postupy a techniky metody zakotvené teorie. Boskovice: Albert.

Strauss, A. L., \& Corbin, J. (2008). Basics of Qualitative Research: Techniques and Procedures for Developing Grounded Theory. London: Sage.

Špirudová, L. (2015). Doprovázení v ošetřovatelství II. Doprovázení sester sestrami, mentorování, adaptační proces, supervize. Praha: Grada Publishing.

Štastný, V. (2017). Aktuální pohledy na vzdělávání v Rakousku: zpráva ze studijního pobytu ve Vídni. Pedagogická orientace 27(3), 504-512. Dostupné z: https://journals.muni.cz/pedor/article/view/8448 
Švingalová, D. (2006). Stres a „vyhoření“ u profesionálů pracujicích s lidmi. Liberec: Technická univerzita.

Thorup, A., \& Thorup, Å. (2006). Elevassistentens yrkesroll. Ett assistentperspektiv. Skolutveckling och ledarskap, Specialpedagogisk påbyggnadsutbildning, Lärarutbildningen. Malmö: Högskola.

Timulák, L. (2005). Základy vedení psychoterapeutického rozhovoru. Praha: Portál.

Titzl, B., \& Vojtko, T. (2011). Vývoj a konstituování oboru speciální pedagogiky.

E-learningový text, projekt Implementace nových forem výuky ve speciální pedagogice CZ.1,07/2.2.00/15.0088. Liberec: Technická univerzita v Liberci.

Troman, G. (2000). Teacher's stress in the low-trust society. British Journal of Sociology of Education, 21(3) [online]. Dostupné z: https://www.researchgate.net/ publication/248992923_Teacher_Stress_in_the_Low-Trust_Society

Tuček, M., Machonin, P. (1993). Prestiž povolání v České republice v roce 1992. Sociologický časopis, 29(3), 367-381.

Úlehla, I. (2005). Umění pomáhat. Praha: Slon.

UNESCO. (2005). Guidelines for inclusion: Ensuring access to education for all. Paris: UNESCO [online]. Dostupné z: http://unesdoc.unesco.org/ images/0014/001402/140224e.pdf

Vacínová, M. (1995). Psychologie a společenská výchova. Praha: Victoria Publishing. Vágnerová, M. (2004). Psychopatologie pro pomáhající profese. Praha: Portál. Valentová, L. et al. (2013). Školní poradenství. Praha: Univerzita Karlova v Praze. Veselá, J. (2010). Zdravotně znevýhodněná rodina aneb klopýtání životem. Brno: Masarykova univerzita.

Vítková, M. (ed.). (2004). Otázky speciálně pedagogického poradenství. Základy, teorie, praxe. Brno: MSD.

Vládní výbor pro zdravotně postižené občany. (2015). Národní plán podpory rovných př́ležitostí pro osoby se zdravotním postižením na období 2015-2020 [online]. Dostupné z: https://www.vlada.cz/assets/ppov/vvzpo/dokumenty/Narodni-planOZP-2015-2020_2.pdf

Vobořilová, J. (2015). Duševní hygiena a stres. Praha: České vysoké učení technické. Vondráček, L. (2001). Hippokratova přísaha. In Česká lékařská komora, okresní sdružení Ústí nad Orlicí. [online]. Dostupné z: http://www.clkuo.cz/dokumenty/ prolekare/hippokratova_prisaha.htm.

Všeobecná deklarace lidských práv a svobod. www.msmt.cz [online]. @ 2020 [cit. 2020-11-1]. Dostupné na: http://www.msmt.cz/file/39238/

Vyhláška č. 35/1992 Sb., o mateřských školách [online]. In Zákony pro lidi. Dostupné z: https://www.zakonyprolidi.cz/cs/1992-35

Vyhláška č. 412/2006 Sb., vyhláška, kterou se mění vyhláška č. 317/2005 Sb., o dalším vzdělávání pedagogických pracovníků, akreditační komisi a kariérním systému pedagogických pracovníků [online]. In Zákony pro lidi. Dostupné z: https://www.zakonyprolidi.cz/cs/2006-412\#f4364358

Výrost, J., \& Slaměník, I. (2008). Sociální psychologie. Praha: Grada Publishing. 
Vyšínová, P. (2013). Článek 22 - Psychohygiena: Téma podpora učitele. In Mají na to! Jak podpořit sociálně znevýhodněné děti na ZŠ (s. 110-114). Praha: Člověk v tísni, o.p.s. [online]. Dostupné z: http://www.majinato.cz/majinato_web.pdf

Waltman, S. H., Frankel, S. A., \& Williston, M. A. (2016). Improving clinician selfawareness and increasing accurate representation of clinical competencies. Practice Innovations, 1(3), 178-188. doi: 10.1037/priooooo26.

Weiss, P. (2011). Etické otázky v psychologii. Praha: Portál.

Werning, R., \& Avci-Werning, M. (2015). Herausforderung Inklusion in Schule und Unterricht, Grundlagen, Erfahrungen, Handlungsperspektiven. Seelze: Kallmeyer.

Wilhelm, M., Bintinger, G., \& Eichelberger, H. (2002). Eine Schule für dich und mich! Innsbruck: Studien Verlag.

Zákon č. 108/2006 Sb., ze dne 14. března 2006, o sociálních službách. In Zákony pro lidi [online]. Dostupné z: https://www.zakonyprolidi.cz/cs/2006-108\#f3009617

Zákon č. 111/2006 Sb., ze dne 14. března 2006, o pomoci v hmotné nouzi. In Zákony pro lidi [online]. Dostupné z: https://www.zakonyprolidi.cz/cs/2006-111\#f3011852

Zákon č. 198/2009 Sb., ze dne 23. dubna 2008, o rovném zacházení a o právních prostředcích ochrany před diskriminací a o změně některých zákonů (antidiskriminační zákon). In Zákony pro lidi [online]. Dostupné z: https://www.mvcr.cz/soubor/sbo58-09-pdf.aspx

Zákon č. 29/1984 Sb., o soustavě základních a středních škol. In Zákony pro lidi [online]. Dostupné z: https://www.zakonyprolidi.cz/cs/1984-29?citace=1

Zákon č. 359/1999 Sb. ze dne 9. prosince 1999 o sociálně-právní ochraně dětí. In Zákony pro lidi [online]. Dostupné z: https://www.zakonyprolidi.cz/cs/1999-359\#f3948025

Zákon č. 46/2019 Sb., zákon, kterým se mění zákon č. 561/2004 Sb., o předškolním, základním, středním, vyšším odborném a jiném vzdělávání (školský zákon) ve znění pozdějších předpisů. In Zákony pro lidi [online]. Dostupné z: http://www.msmt.cz/ dokumenty-3/skolsky-zakon

Zákon č. 47/2019 Sb., ze dne 31. ledna 2019, zákon, kterým se mění zákon č. 108/2006 Sb., o sociálních službách, ve znění pozdějších předpisů. In Zákony pro lidi [online]. Dostupné z: https://www.zakonyprolidi.cz/cs/2019-47\#f6385740

Zákon č. 89/2012 Sb., ze dne 3. února 2012, občanský zákoník. In Práce pro pracovníky [online]. Dostupné z: http://www.pracepropravniky.cz/zakony/novy-obcanskyzakonik-2014-uplne-zneni

Zákon č. 94/1963 Sb., ze dne 4. prosince 1963, o rodině. In Zákony pro lidi [online]. Dostupné z: https://www.zakonyprolidi.cz/cs/1963-94\#castl

Zákon č. 561/2004 Sb., ze dne 24. září 2004, o předškolním, základním, středním, vy̌̌ším odborném a jiném vzdělávání (školský zákon) ve znění pozdějších předpisů. In Zákony pro lidi [online]. Dostupné z: http://www.msmt.cz/dokumenty-3/skolsky-zakon

Zákon č. 563/2004 Sb., ze dne 24. září 2004, o pedagogických pracovnících a o změně některých zákonů, ve znění pozdějších předpisů. In Zákony pro lidi [online]. Dostupné z: http://www.msmt.cz/file/38850/

Zapletalová, J. (2001). Co dělá školní psycholog? Kritická místa profese. Mimořádné číslo Aktuální otázky vzdělávání dětí se speciálními vzdělávacími potřebami.

Pedagogika, 36-46. 
Zapletalová, J. (nedat.) Školní poradenské pracoviště (ŠPP) [online]. Praha: Národní ústav pro vzdělávání. Dostupné z: http://www.nuv.cz/t/pedagogicko-psychologickeporadenstvi/skolni-poradenska-pracoviste.

Zezulková, E. (2004). Speciální pedagogika - úvod do problematiky. Ostrava: Ostravská univerzita.

Zilcher, L., \& Svoboda, Z. (2019). Inkluzivní vzdělávání: efektivní vzdělávání všech žáků. Praha: Grada Publishing. 


\section{Seznam tabulek a obrázků}

$\begin{array}{lll}\text { Tab. } 1 \text { Vlastnosti a dimenze kategorie } 1 & 57\end{array}$

Tab. 2 Vlastnosti a dimenze kategorie $2 \quad 60$

Tab. 3 Vlastnosti a dimenze kategorie $3 \quad 62$

Tab. 4 Vlastnosti a dimenze kategorie $4 \quad 64$

Tab. 5 Vlastnosti a dimenze kategorie $5 \quad 67$

Tab. 6 Vlastnosti a dimenze kategorie $6 \quad 71$

$\begin{array}{lll}\text { Tab. } 7 & \text { Vlastnosti a dimenze kategorie } 7 & 74\end{array}$

Tab. 8 Vlastnosti a dimenze centrální kategorie 82

Tab. 9 Vlastnosti a dimenze procesů směřujících $\mathrm{k}$ zakotvené teorii $\quad 87$

Obr. 1 Kroky zakotvené teorie (Strauss \& Corbinová, 2008) 54

Obr. 2 Mapa konceptů na základě otevřeného kódování 56

Obr. 3 Paradigmatický model axiálního kódování 78

Obr. 4 Paradigmatický model selektivního kódování 85

Obr. 5 Matice podmiňujících vlivů (Strauss \& Corbinová, 1999, s. 121) 88 


\section{Věcný rejstřík}

A

adaptace $39,42,44$

ADHD 58, 68

administrativa $35,57,58,59,62,65$,

69, 76, 79, 83, 93

agenda školního speciálního

pedagoga 7, 53, 55-57, 78, 79, 91, 92

asistent pedagoga $13,18,25,57-60$,

$63,70,73,79$

Aspergerův syndrom 58

atmosféra školy 23, 32, 75, 90

autoregulace 42,45

axiální kódování 54, 77, 78, 81, 82,

86,92

\section{B}

byrokracie $43,57,65,68$

C

citová deprivace 32

$\check{\mathrm{C}}$

Činnosti školního speciálního pedagoga 6-8, 23-26, 29-31, 49, 58, $59,69,79,83-87,89,90,92,93$

D

defektologie 8,11

diagnostika 15, 25, 26, 34, 51, 58, 69

diferenciace 19, 20

diplomatické jednání 56, 57, 61-63,

71-73, 77, 78, 80, 81, 83-88, 91-93,

95,96

diverzita 16

duševní (vnitřní) rovnováha 38,40 ,

$42,43,47$

E

empatie $29,32,52,61,69,73$

etické aspekty profese 6, 48-52, 97

etický kodex 25, 32, 33, 50, 97 etika výzkumu 51

exkluze 14,19

$\mathbf{F}$

financování, finanční

ohodnocení $24,25,27,38,57,75$

flexibilita 19, 31

\section{H}

hlavní vzdělávací proud 5, 8, 12-18, 22

\section{I}

identita školního speciálního pedagoga $56,60,78$

image profese 31

Index inkluze 19

individualizace 12, 20, 27

individualizace vzdělávání 27

individuální vzdělávací plán 7,25, 35,58

inkluze 5, 7, 8, 14-17, 19, 56, 67, 68-70, $74,76,81,84,94$

inkluzivní politika 18

inkluzivní škola 17, 19, 68, 74, 76

inkluzivní vzdělávání 5, 8, 14-16, 18, 19, 67, 68, 115

intaktní osoba, společnost 9-11,

13,14

integrace $7,8,10,13-16,19,25,54,58$, $65,67-69,76,81,84,91,92$

integrované vzdělávání 15

intervence $26,32,34,50,57,58,61$, 70, 92

$\mathbf{K}$

klima školy 23, 25, 92

kompetence školního speciálního pedagoga $8,28,29-35,51,57,59,62$, $75,83,86,89,90,92$

kompetence žáků 96 
komunikace $16,23-25,28,33-35,36$, $56,59-63,65,71,73,79-83,85-90$,

$93,95,96$

komunitní škola 35

kostra príběhu 81, 83-85, 93

kouč 41,46

kreativita 29

kvalitativní výzkum 53, 94

L

Listina základních práv a svobod 8 , 10,50

\section{M}

matice podmiňujících vlivů 87-91, 93

mediátor 33, 34

minoritní skupiny 5

model péče 7

preventivně intervenční 25

terapeutický 25

morálka, morální zásady 48, 49, 52,

97

motivace $28,30,32,36,38-40,88,97$

$\mathbf{N}$

nápravná pedagogika 11

nerovné šance ke vzdělávání 17

neziskové organizace 36,84

0

Orgán sociálně-právní ochrany dítěte (OSPOD) 31, 36, 59, 71, 84

osobní asistent 18

osobnost školního speciálního

pedagoga 32,34

osobnostní předpoklady 41, 52, 91

osobnostní, sebezkušenostní

výcvik 27, 29, 36, 41, 42, 46, 63

otevřené kódování 54-56, 91, 92

otevřenost $23,55,61,73-75,90$

$\mathbf{P}$

paradigmatický model (schéma) 78, 79, 83, 85, 93

pedagogicko-psychologická

poradna (PPP) 13, 21, 22, 25, 26, 31,

$33,35,58,59,71$

pedologie 10,11

pedopatologie 10,11

podpůrná opatření $16,18,25,35,68$, 74-76, 81 policie 36,84

městská policie 36

Policie ČR 36

polostrukturovaný rozhovor 53

pomáhající profese $6,32,37,44,47$,

48, 49, 51, 52, 97

poradenství $7,21,22,27,58-60$

kariérové (kariérní) 22, 25

pedagogicko-psychologické 21 speciálněpedagogické 25,27 ,

58-60

poruchy autistického spektra, autismus 58

postižení 8-16, 58, 62, 67

duševní 10

mentální 13,58

mravní 10

tělesné (somatické) 10, 13, 68

smyslové (zrakové, sluchové) 9, 13

povinná školní docházka 12, 15, 27

pracovní kolektiv $66,75,77,81$

pracovní prostředí (klima) 40, 41, 44

pracovní zátěž $5,6,39,40,43,47,53$,

54, 80, 91, 96

právo na vzdělání $8,15,19$

profesní obraz 6,53-95

profesní role $6,30,31,53,54,79,81-94$

psychohygiena $37,40-43,45,46,53$,

$64,73,84,86,96$

$\mathbf{R}$

reedukace 25

relaxace $42,43,64$

rodina, rodiče, rodiče dítěte

s postižením $5,7,8,12,13,15,17,19$,

21-36, 41, 44, 46, 51, 54, 56, 58, 59-66,

$68,70-75,77,79,81,83,84,88-90$,

92, 93, 96

rovné vzdělávání, příležitosti 5, 21, 24,96

růst

osobnostní 14, 22, 23, 40-42, 46, 50,

$53,87,86,97$

profesní (odborný) 50, 86

$\check{\mathbf{R}}$

ředitel $12,13,22,24,27,28,31,75,88$

$\mathrm{S}$

sdílení 44, 50, 57, 62, 66, 73

profesní 28, 30, 32, 46, 47, 62, 86

sebepojetí 29 
sebepoznání 37, 42, 46

seberealizace $38,40,42$

sebereflexe $29,40,42$

seberozvoj 29, 30, 42

sebeuvědomění 46

sebevýchova 40,42

segregace $5,8,11-14,16,67$

segregovaná výchova a

vzdělávání 9-11, 14,17

selektivní kódování 54, 81, 83, 85,

92, 93

schopnosti žáka 15

snížený intelekt 68,76

sociální pedagog 22, 23, 28, 89

sociální role 31, 82, 83

sociální znevýhodnění 14, 15, 17, 23

speciálněpedagogické centrum

(SPC) 13, 21, 22, 25, 26, 31, 33, 35, 50,

$58,63,71$

speciální pedagogika $8,11,13,14,27$

specifické poruchy učení (SPU) 8,58

specifické (speciální) vzdělávací

potřeby $13,15-17,19,22,23,25,27,96$

spolupráce

odborná $7,8,13,23,25,28,35,36,50$,

51, 53, 55-59, 62-64, 80, 81, 84, 89, 90,

94

spolupráce s rodinou (rodiči) 8,15 ,

$30,31,33,34,62,63,65,73,77,81$

stigmatizace 12

strategie zvládání, copingové

strategie $5-7,44-47,53,54,64,65$,

$77,84-87,91,94$

stres $6,7,38-47,53,56,64-66,72$,

77-81, 84-86, 90, 91, 93-96

středisko rané péče 13

středisko výchovné péče (SVP) 13 ,

$18,21,23-26,35,36,50,84,91$

supervize $27,37,41,47,50,66,72$

syndrom vyhoření $29,36,38,40,66$,

93

systém vzdělávání dvojkolejný

(two-track) 17-19

systém vzdělávání jednokolejný

(one-track) 17,18

systém vzdělávání vícekolejný

(multi-track) 17, 18-20
$\check{\mathbf{S}}$

školní metodik prevence 21, 22, 31,

$36,58,59,65,90$

školní poradenské pracoviště

(ŠPP) $5,7,13,21-25,31,35,37,51,57$,

$58,61,62,64,75,76,86,88,89,92,94$

školní psycholog 5, 7, 21-23, 27, 28, 34, $46,49,57,59,75,89$

školská poradenská zařízení

(ŠPZ) 5, 16, 21, 22, 25, 35, 84, 89

školský zákon 12, 15, 16, 18, 22

$\mathbf{T}$

terapie 46

aromaterapie 43

psychoterapie 36,42

time management 41

transformace $11,13-15$

tř́dní schůzky 34, 58, 59

\section{Ú}

Úmluva o právech dítěte 50

\section{V}

vedení školy 5, 2, 29, 31, 33, 41, 43, 59,

$62,65,66,69,71,73,75,76,79-81$,

84-86, 88

volný čas $38,43,46,47,64,65$

výchovný poradce 21-23, 31, 36

\section{$\mathbf{Z}$}

zákonný zástupce 13, 25, 33, 50

zakotvená teorie $6,53-55,81,86,87$, 94

zastupitelnost 64

zátěžové situace 39, 44, 45, 95

zdraví 40-42, 44, 48, 66, 75, 94

$\check{\mathbf{Z}}$

životní styl 10, 42

životospráva 42 


\section{Jmenný rejstřík}

A

Ainscow, M. 19

Avci-Werning, M. 19

B

Bartko, D. 41

Bartoňová, M. 18, 19

Baslerová, P. 21, 24

Bedrnová, E. 40-42

Bintinger, G. 17

Bishoff, H. 49

Booth, T.

Boyle, G. J. 44

Brodie, J. D. 46

Buchtová, B. 38

Buchwald, P. 39

\section{C}

Cakirpaloglu, P. 39

Carver, C. S. 45

Cooper, C. D. 44

Cooper, E. 38

Corbinová, J. 53-55, 78-83, 86-88, 94

$\check{\mathrm{C}}$

Čedík, M. 50

Čech, T. 6, 22, 23, 40, 50

Černý, V. 39

Čerstvá, L. 23

D

Decker, W. H. 44

Dobešová Cakirpaloglu, S. 38, 40

Docking, J. 33

Drotárová, E. 43

Drotárová, L. 43

Ďurič, L. 40

Dyson, A. 19

E

Eichelberger, H. 17
F

Felcmanová, L. 21

Feyerer, E. 20

Fialová, K. 24

Foucault, M. 9

Folkman, S. 45

Fontana, D. 39

Frankel, S. A. 46

G

Gelkopf, M. 44

Giddens, A. 39

Goldmanová, S. 49

Greger, D. 16

Grofová, K. 39

H

Halík, T. 52

Haškovcová, H. 49

Hormandlová, T. 6

Hytych, R. 53, 55, 77, 78, 94

I

Iatridou, E. 18

Ingstrup, M. S. 46

J

Jandourek, J. 30, 82, 93

Jankovský, J. 48, 49, 52

Janků, K. 8-10

Jennessen, S. 19

Jesenský, J. 8-10, 14

Jirásko, J. 27

Josefsson, Ch. 18

Joss-Reid, J. M. 44

K

Kasíková, H. 12, 16

Keller, J. 30

Knotová, D. 28

Kopřiva, K. 32 
Kovářová, R. 13, 21

Kratochvílová, J. 15, 17

Kreitler, S. 44

Křivohlavý, J. 29, 38-40, 42, 45

Kucharská, A. 7, 10, 13, 16, 21-26, 28-30, 32-36, 46, 47, 49-52

L

Lazarová, B. 15

Lazarus, R. S. 39, 44-46

Lechta, V. 14, 15, 49

Lemrová, S. 38

Lišková, K. 32

Lovaš, L. 45

\section{M}

Machonin, P. 41, 83

Márová, I. 41

Matějček, Z. 33

Matoušek, O. 30, 32, 82, 93

Matulayová, T. 8

Mertin, V. 22

Míček, L. 40-43

Michalík, J. 11-13, 21

Miovský, M. 55

Mrázková J. 7,8

Musil, L. 32

\section{$\mathbf{N}$}

Nakonečný, M. 30, 82, 93

Nedělníková, D. 32

Novosad, L. 22

\section{0}

Oakland, T. 49

\section{$\mathbf{P}$}

Pančocha, K. 16

Pastieriková, L. 24

Paulík, K. 39-45, 47

Pešatová, I. 8,10

Peterková, M. 41, 42

Pilař, J. 13, 15, 19, 27, 28

Polechová, P. 17

Průcha, J. 18, 41, 51, 83

Ptáček, R. 49

\section{$\mathbf{R}$}

Reamer, F. 32

Reiter, N. 46

Renotierová, M. 11

Resman, M. 15
Rotondo, D. M. 44

Rupert, P. A. 44, 46

Růžička, M. 23, 24, 29, 30, 35

$\check{\mathbf{R}}$

Řiháček, T. 53, 55, 77, 78, 94

\section{S}

Santiago, P. 17

Scheier, M. F. 45

Schmidnauer, W. 29

Simonová, P. 17

Skär, L. 18

Slaměník, I. 30, 82, 83, 93

Slavíková, I. 50, 51

Slepičková, L. 16

Smékal, V. 29

Smolíková, M. 24

Soják, P. 23

Sovák, M. 8-11

Stevanovic, P. 44, 46

Stock, Ch. 41, 43, 47

Straková, J. 16, 17

Strauss, A. L. 53-55, 78-83, 86-88, 94

$\check{\mathbf{S}}$

Špirudová, L. 30, 31, 82, 93

Štastný, V. 20

Švaříček, R. 51

Švingalová, D. 39

$\mathbf{T}$

Tam, M. 18

Thorup, A. 18

Thorup, Å. 18

Timulák, L. 30

Titzl, B. 10

Toman, J. 26

Tomická, V. 8,10

Troman, G. 41

Tuček, M. 41, 83

U

Úlehla, I. 29, 36

V

Vacínová, M. 41, 43, 47

Vágnerová, M. 38

Valentová, L. 21, 22

Veselá, J. 9, 10

Vitásková-Janků, K. 13, 21

Vítková, M. 7, 18, 19 
Jmenný rejstřík

Vobořilová, J. 42

Weiss, P. 37, 43

Vojtko, T. 10,11

Werning, R. 19

Vondráček, L. 48

Wilhelm, M. 17

Výrost, J. 30, 82, 83, 93

Williston, M. A. 46

Vyšínová, P. 41

W

$\mathbf{Z}$

Waltman, S. H. 46

Zapletalová, J. 22, 25, 34

Zezulková, E. 8

Weintraub, J. K. 45 


\section{Shrnutí}

Publikace se zaměřuje na profesi školního speciálního pedagoga na základní škole. S oporou aktuálních odborných poznatků a legislativních dokumentů reflektuje potřebu tohoto profesionála ve školním prostředí, kde se v rámci školního poradenského pracoviště stává jedním z klíčových článků podporujících úspěšnost inkluzivního vzdělávání. Na základě kvalitativního výzkumu, realizovaného metodou polostrukturovaných rozhovorů s praktikujícími školními speciálními pedagogy, podchycuje kniha prostřednictvím zakotvené teorie specifika profese, její úkoly a pracovní náplň ve vztahu ke všem aktérům výchovně-vzdělávacího procesu ve škole, tedy dětem, jejich rodičům, učitelům a dalším odborníkům působícím v rámci školy i školských poradenských zařízení. Současně se věnuje strategiím zvládání pracovní zátěže a způsobům psychohygieny školních speciálních pedagogů. Monografie rovněž zaznamenává, jakým způsobem školní speciální pedagogové vnímají svou profesní roli a účast na životě školy.

Klíčová slova: Školní speciální pedagog, základní škola, školní poradenské pracoviště, inkluzivní vzdělávání, pracovní náplň, pracovní zátěž, stres, strategie zvládání, psychohygiena, kvalitativní výzkum, zakotvená teorie. 


\section{Summary}

The publication focuses on the profession of a special education coordinator in elementary school. Building on the current scientific knowledge and relevant legislative documents, the book reflects on the need for these specific professionals in school counselling centres where they become one of the key elements in supporting the concept of inclusive education. Based on a qualitative research study carried out by means of semi-structured interviews with special education coordinators, the authors used the grounded theory approach to analyse the specifics of the profession as well as its tasks and job description in relation to all actors of the educational process including children, parents and other professionals in schools and educational counselling centres. At the same time, the publication addresses the workload, coping strategies and mental hygiene approaches among special education coordinators including their perceptions of their own professional roles and participation in the life of the school.

Keywords: Special education coordinator in school, elementary school, school counselling centre, inclusive education, job description, workload, stress, coping strategies, mental hygiene, qualitative research, grounded theory. 


\section{O autorech}

\section{doc. PhDr. Tomáš Čech, Ph.D.}

Je absolventem oborů Učitelství pro l. stupeň ZŠ a Speciální pedagogika na Pedagogické fakultě Masarykovy univerzity v Brně, kde také dokončil doktorské studium V oboru Pedagogika. V něm se také v roce 2011 úspěšně habilitoval. Působí na Ústavu pedagogiky a sociálních studií Pedagogické fakulty Univerzity Palackého v Olomouci, kde se odborně zaměřuje na problematiku edukace dětí s projevy rizikového chování a poruchami chování a jejich odbornou podporu ve školním prostře-

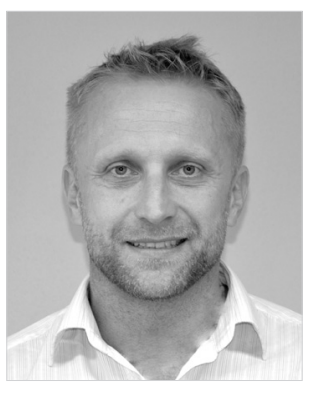
dí. V posledních letech se výzkumně zaměřuje také na další sociální aspekty školního prostředí, mj. uplatnitelnost sociálních pedagogů v rámci školních poradenských pracovišt' a kvalitu klimatu a vztahů v prostředí školy. V letech 2009-2017 zastával pozici předsedy České pedagogické společnosti, aktuálně je jejím místopředsedou.

\section{Mgr. et Mgr. Tereza Hormandlová}

Absolvovala Pedagogickou fakultu Masarykovy univerzity v Brně, kde vystudovala obory Sociální pedagogika a volný čas, Speciální pedagogika pro učitele a program celoživotního vzdělávání Expresivní terapie se zaměřením na arteterapii. Působí jako učitelka v mateřské škole ve třídě pro děti s poruchou autistického spektra a současně studuje doktorské studium na Pedagogické fakultě Univerzity Palackého v Olomouci pod vedením doc. PhDr. Tomáše Čecha, Ph.D. Ve svém disertačním

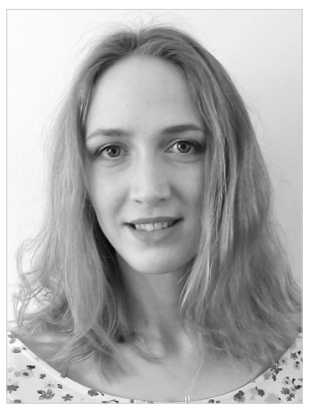
výzkumu se zabývá odbornou podporou dětí se specifickými vzdělávacími potřebami a sociálním znevýhodněním ve škole. 


\section{KATALOGIZACE V KNIZE - NÁRODNÍ KNIHOVNA ČR}

Čech, Tomáš, 1974-

Profesní obraz školního speciálního pedagoga : v podmínkách základní školy / Tomáš Čech, Tereza Hormandlová. -- 1. vydání. -- Olomouc : Univerzita Palackého v Olomouci, 2020. -1 online zdroj

České a anglické resumé

Nad názvem: Univerzita Palackého v Olomouci, Pedagogická fakulta. -- Obsahuje bibliografii a rejstř́ḱky

ISBN 978-80-244-5862-5 (online ; pdf)

* $376.011 .3-051$ * 331.546 * 303.022 * $373.3 *(437.3)$ * $(048.8)$

- speciální pedagogové -- Česko

- profesní kompetence

- kvalitativní výzkum -- Česko

- základní školy -- Česko

- monografie

376 - Výchova a vzdělávání zvláštních skupin osob [22] 


\section{Profesní obraz školního speciálního pedagoga v podmínkách základní školy}

Tomáš Čech

Tereza Hormandlová

Odpovědná redaktorka Tereza Vintrová

Jazyková korektura Tereza Vintrová

Layout a sazba Jitka Bednaříková

Návrh obálky Jiří K. Jurečka

Na obálce je použita ilustrace autora RoonZ-nl, zdroj Pixabay.com

Vydala Univerzita Palackého v Olomouci,

Kř́žkovského 8, 77147 Olomouc

vydavatelstvi.upol.cz

Neprodejná publikace

1. vydání

Olomouc 2020

DOI: $10.5507 /$ pdf.20.24458618

ISBN 978-80-244-5861-8 (tištěná kniha)

ISBN 978-80-244-5862-5 (online: iPDF)

VUP 2020/0344 (tištěná kniha)

VUP 2020/0341 (online: iPDF) 
Publikace se zaměřuje na profesi školního speciálního pedagoga na základní škole. S oporou aktuálních odborných poznatků a legislativních dokumentů reflektuje potřebu tohoto profesionála ve školním prostředí, kde se v rámci školního poradenského pracoviště stává jedním z klíčových článků podporujících úspěšnost inkluzivního vzdělávání. Na základě kvalitativního výzkumu, realizovaného metodou polostrukturovaných rozhovorů s praktikujícími školními speciálními pedagogy, podchycuje kniha prostřednictvím zakotvené teorie specifika profese, její úkoly a pracovní náplň ve vztahu ke všem aktérům výchovně-vzdělávacího procesu ve škole, tedy dětem, jejich rodičům, učitelům a dalším odborníkům působícím v rámci školy i školských poradenských zařízení. Současně se věnuje strategiím zvládání pracovní zátěže a způsobům psychohygieny školních speciálních pedagogů. Monografie rovněž zaznamenává, jakým způsobem školní speciální pedagogové vnímají svou profesní roli a účast na životě školy.

\section{$\mathbb{P}$ \\ Univerzita Palackého v Olomouci}

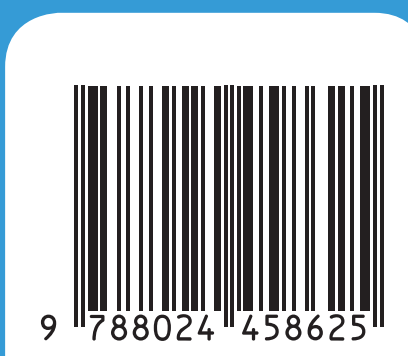

